Louisiana State University

LSU Digital Commons

1979

\title{
A Study of the Relationships Between Span of Supervision and Leadership Directiveness in Fast-Food Restaurants.
}

Foad Derakhshan

Louisiana State University and Agricultural \& Mechanical College

Follow this and additional works at: https://digitalcommons.Isu.edu/gradschool_disstheses

\section{Recommended Citation}

Derakhshan, Foad, "A Study of the Relationships Between Span of Supervision and Leadership Directiveness in Fast-Food Restaurants." (1979). LSU Historical Dissertations and Theses. 3432.

https://digitalcommons.Isu.edu/gradschool_disstheses/3432

This Dissertation is brought to you for free and open access by the Graduate School at LSU Digital Commons. It has been accepted for inclusion in LSU Historical Dissertations and Theses by an authorized administrator of LSU Digital Commons. For more information, please contact gradetd@lsu.edu. 


\section{INFORMATION TO USERS}

This was produced from a copy of a document sent to us for microfilming. While the most advanced technological means to photograph and reproduce this document have been used, the quality is heavily dependent upon the quality of the material submitted.

The following explanation of techniques is provided to help you understand markings or notations which may appear on this reproduction.

1. The sign or "target" for pages apparently lacking from the document photographed is "Missing Page(s)". If it was possible to obtain the missing page(s) or section, they are spliced into the film along with adjacent pages. This may have necessitated cutting through an image and duplicating adjacent pages to assure you of complete continuity.

2. When an image on the film is obliterated with a round black mark it is an indication that the film inspector noticed either blurred copy because of movement during exposure, or duplicate copy. Unless we meant to delete copyrighted materials that should not have been filmed, you will find a good image of the page in the adjacent frame.

3. When a map, drawing or chart, etc., is part of the material being photographed the photographer has followed a definite method in "sectioning" the material. It is customary to begin filming at the upper left hand comer of a large sheet and to continue from left to right in equal sections with small overlaps. If necessary, sectioning is continued again-beginning below the first row and continuing on until complete.

4. For any illustrations that cannot be reproduced satisfactorily by xerography, photographic prints can be purchased at additional cost and tipped into your xerographic copy. Requests can be made to our Dissertations Customer Services Department.

5. Some pages in any document may have indistinct print. In all cases we have filmed the best available copy.

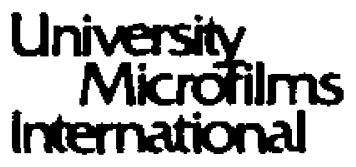

Whi IE

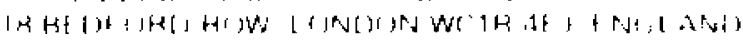


DERAKHSHAN, FOAD

A STUDY OF THE RELATIONSHIPS BETWEEN SPAN OF SUPERVISION AND LEADERSHIP DIRECTIVENESS IN FAST-FOOD RESTAURANTS

The Louisiana State University and Agricultural and Mechanical Col.

PH.D.

1979

\section{University Microfilms}

International $300 \mathrm{~N}$ Zeeb Rod, An Atbor, M1 48106

18 Bedford Row, London WCIR 4EJ, England 
PLEASE NOTE:

In all cases this material has been filmed in the best possible way from the avatiable copy. Probiens encountered with this document have been identified here with a check mark $\square$.

1. Glossy photographs

2. Colored fllustrations

3. Photographs with dark background

4. Illustrations are poor copy

5. Orint shows through as there is text on both sides of page

6. Indistinct, broken or small print on several pages throughout

7. Tightly bound copy with print lost in spine

8. Computer printout pages with indistinct print

9. Page(s)_ lacking when materfal received, and not avaliable from school or author

10. Page(s) follows seem to be missing in numbering only as text

11. Poor carbon copy

12. Not original copy, several pages with blurred type

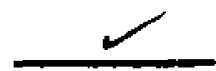

13. Appendix pages are poor copy

14. Original copy with light type

15. Curling and wrinkled pages

16. Other

Uriversity

Microfilms

Internarional 
A STUDY OF

TUE REIATIONSUIPS RETWEEN SPAN OF SUPERVISION

AND IEADERSHIP DIRECTIVENESS IN

PAST-POOD RESTAURANTS

\author{
A Dissertation \\ Subnitted to the Graduate Faculty of the \\ Joulstana state Universit." and \\ Arricultural and Nechanlcal collere \\ in partial fulfiliment of the \\ requirements for the depree of \\ Doctor of Philosonhy \\ in \\ The Department of Management
}

\title{
by
}

Foat Derakheren

A.S. Tehran Pusiness Collere, Tehron, 1973

M.F. A., Loulsiana state Iniversity, 197k

Decemper, 1979 


\section{A TYNCII EDOENENTS}

The accomplishment of this work kould have not been possitile without the assistence and cooderation of a number of Individuals and oraanizations. I em deeply araterul to all who olaved an instrumental role in this accomolishment, al thouph not oll of ther are mentioned here.

I especially thank my dissertation compltee: Dr. vertert s. Ficks, chalroan of complttee, for his subsort and arvice throukhout $7 \because$ Hoctoral work: Tr. C. J. "arris and Dr. Eugene r. Forann, for their valuahle guldance and coments on this work; Dr. Edmund Fray and Dr. Rotert Elammane, for their encourafement and sindort. I aw indetted to Dr. Fart Fartring for his generous helo and guldance in the dataanalisis phase of this work. I olso wish to thenk my friend Dr. Kamal Faterl for his editorial quidance and encourageTent.

Finaliy. I an trankful to Miss Clarlssa Plate for the Dersona? care and interest she invested in her secretarlal and editorla? hels. 
Pare

ACKNOWLEDIEMENTS . . . . . . . . . . . . . . 11

LIST OF TALIES . . . . . . . . . . . . . . . v1

LIST OE FI URES . . . . . . . . . . . . . . . . v11

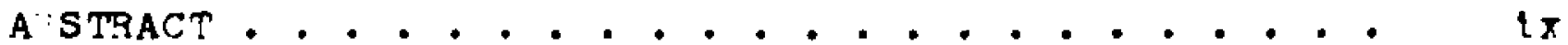

Chapter

I. INTRODICTION . . . . . . . . . . . . 1

Importance of Leaderghid and Span of Supervision 3

Purbose of the study and statement of the

Problem...................

Definition of the Varlables of the pesearch. .

Structural Varlatle..............

Ieadersh1o Varianles . . . . . . . . .

Structurgl/Leadersh1o parianle . . . . .

Hyootheses

Scope and Imitations of the stidy : : : :

Justification for the study..........

Preview...................

II. REVIEN OF LITERATURE . . . . . . . . . . 14

Span of Sudervision/I eadershid ........ 1 .

Span of Supervision/centralization . . . . . 18

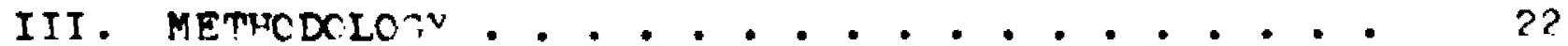

The Type of Work rroup Sampled . . . . . . 2 2 ?

The Samole and Method of Data Collection : . 26

The Instruments ................ 29

The Data Analysis Techniques ........ 31

The Pretest and Revision of the Questionnalre. 33

IV. STATISTICAI. ANAIVSIS . . . . . . . 35

Correlation and Regression Analysis..... . 35 
Correlation Coefficient . . . . . . . . other Statistios in Regression Analysis..

Steps in Determining the Association Between Varlables *................

Limitations of Correlation and Regression Analysis.................... Characteristics of the Sample .......... Correlation Coefficient Statistics...... Correlations of Major Variables . . . . . .

Correlations Between Major Variables and Classification Variables.........

Discrete classification Varianles and Their Relationships to other Variatles..... . Further Analysis of Focal Associations . . .

Relationship Between Actual (Percelved)

Initiation of Structure and 3 pan of Supervision

Relationship Between Actual (Percelved) Consideration and Span of Supervision..

Non-signiflcant Relationships ........ Summary of the Statistical Results....... Summary of Results by Hypothesis........

V. INTERPRETATION OF THE RESIITS, CONCLUSIONS, AND SUGGESTIONS FOR FURTHER QESEARCH . . . . .

Summary of the Study ................ Relationship Between span of Supervision and

Directiveness of Leadership Style .....

Interpretation of the Relationship Between Span and Initiation of Structure..... .

Interpretation of the Relationship Between Span and Consideration...........

Interpretation of the Relationship Between Inltiation of structure and consideration.

Summary of the Relationships of span to

Inltiation of structure and Consideration. Interpretation of the Relationship Between

span and Centralization Variables ... Summary of the Relationship Fetween span

and Centralization............. Supplewentary Relationships . . . . . . . . . Summarv and Conclusion ............. Suggestions for Further Research . . . . . . . 
Page

RIRIIOGRAPLY . . . . . . . . . . . . . . .

APPENDICES . . . . . . . . . . . . . . .

A. Emplovee Questionna1re: Subscales and Scoring Formats . . . . . . . . . . . . . . . .

B. Supervisor Opinion Questionnalre: Sutscales and Scorling Formats . . . . . . . . . .

C. Revised Emolovee Questionnaire ........

D. Revised Supervisor Opinion Questionna1re .

E. Cover Letter for the Supervisor opinion Questionnalre ................

F. Cover Letter for the Emplovee Questionnalre .

G. Self-Instructed Envelope for the Employee Questionnalre... . . . . . . . . . .

T. Permission Requests for the Use of Questionnalre Subscales and Subsequent Authorizations

I. Correlation Matrix . . . . . . . . . 


\section{LIST OF TAPIES}

Tahle

Page

3-1 Fast-Food Restaurants in the Sample.....

4-1 Characteristics of the Sample........

4-2 Correlation Coefficients Measuring the Degrees of Assoclation netween Major Variables. . . .

4-3 Correlation Coefficients Measuring the Degrees of Association petween Ieadersh1p and Classiflcation Varlahles. . . . . . . . . . . .

4-4 Results of the Repression petween Actual In1tiation of Structure and Span of Supervision

4-5 Results of the Regression ?etween Actual In1tiation of structure and Span of Supervision for Male Emplovees .............

4-6 Results of the Regression netween Actual In1tiation of Structure and Soan of Supervision for Female Emplovees . . . . . . . . .

4-7 Results of the Regression Between Actual Consideration and Span of Supervision .....

4-8 Results of the Regression etween Actual Consideration and Span of Supervision for Male Emplovees.................

4-9 Results of the Regression Retween Actual Consideration and Span of Supervision for iemale Emplovees.................. 


\section{IIST OF FICIRES}

Flgures

Page

4-1 Scatter Diarram for Soan of Supervision and Actual Initiation of Structure . . . . . . . .

4-? Fitted Rearession I ine for Soan of Supervision and Actual Initiation of structire.......

4-3 Scatter Diagram for Span of Supervision and Actual Initiation of Structure (Male Emplovees)

4-4 Fitte? Rerression I ine for soan of supervision and Actixal Initiation of structire ("ale Emplo:ees)

4-: Scatter Diagram for Span of Supervision and Actual Initiation of Structure (Female Employees

4-6 Titted perression Line for span of Supervision and Actual Initiation of Structure (Female Inolovees)

4-7 Scatter Diarram ror san of Supervision and Actual Consideration ..............

4-? Tited qerression Line for Soan of Suoervision and Actial Consideretion ...........

4-9 Scatter Diarran for Span of Supervision and Actual Consideration . . . . . . . . . . .

4-10 Fitted Repression Line for soan of supercision and Actial consideration (Nale Emplorees) . .

4-11 Scatter Dlagrer for Soan of Supervision and Actual Consiteration (Female Emplo:'es) . . .

4-1? Fitted Regression Iine for Soan of Supervision and Actial Consideratior (Female Employeesl. .

4-13 Scatter Diagram for Actual Inttiation of structure and Expressed Initiation of Structure. . 
F1gures

Page

4-14 Scatter D1agram. for Actual Coneideration and

Expressed Consideration . . . . . . . . . .

4-15 Scetter riagrat for soan of Supervision and Personal Particioation in Declsion "aking. .

4-16 Scatter Diagram for Span of Supervision and Herarchy of Authorlt? 


\section{A'STRACT}

The concedts of soan of supervision and leadershio are anong the earliest 1 ssues whlch attracted the attention of organizational and hehavioral theorists; however, the studies that focus on the relationship between the two variables are rare and inconsistent. Th1s study attemoted to detect correlations tetween span of supervision and several dimensions of leadershio directiveness. Two tydes of varlables measured the directiveness of leadershio. The rirst class of variables inclinted the commonly used learership varlables of "Initiation of structure" and "consideration." The second class of varla-les possessed structural attributes and Included "perticipetion in decision making" and "hierarchy of authorlty," which together neusure the derree of centralization. It was not the purpose of this study to search for callsal relationshios netween the varianles. The generalization of the findings is 11 mited by the methodological restrictions.

To test the hypotheses oronosed, nine fast-food restaurants were chosen for field research since they oresented bartichlar characterlstics which mode them sultable for this stury. A sample of 94 emolovees ond thelr surervisors completed an "Emplovee huestionnalre" and a "Sudervior 
Opinion Questionnalre," respectivelv. The questionnalres used in the research were composed of subscales from instruments used in The Chio State Universitv leadership otudies (19,3 revisions) and in centralization atudies hy trage and Alken (2967). The questionnalres were pretested and revised before teing used for data collection in the rield.

The analysis of the results indicated that the supervisors with a wider span were percelved to exert less initietion of structure and to show less consideration, while when the span was narrow the supervisorstended to inltiate more structure and to ne more concerned with emplovecs' feelings. The relationship metween the two variailes of initiation of structure and consideration was $a$ positive one. A posaltie explanation of the findings was orovided with a reference to the situational context of the restaurants. Earlier research suagested that due to the lahor prohlem in restaurants a coordinative "henevolent autocracy," 1.e., high initiation of structure jolned with high consideration, seems to be the appropriate leadership stvie hut 1 t 18 hari to achleve as the span widens. This explanation is also reconfirmed by the fluding of the study that herond the span of 18 to 20 both dimensions of leadership hehavior declined aharply. 
Interestingl", how the supervisor acted was unrelated to $\mathrm{h} 1 \mathrm{~s} / \mathrm{her}$ belief on what constituted an "appropriate" leadership behavior. The older managers and managers with less work experience belleved in the exertion of more initlation of structure and more consideration: however, they did not practice what they preached. In general, the more experienced managers' action came closest to what was referred to as "benevolent autocracy." Employee sex had an effect on how the emolovee percelved the supervisor's tehavior; therefore, it affected the measurement of relevant relationshlps. Contrar. to common beliefs, no signiflcant relationships were found hetween the span and the superv1sors' cholce of a participative leadership style, or his delegation of all thority. 
CDAPTEP I

\section{INTRCDUCTION}

The concepts of or canizetional structure, power, and leadershlo are interrelated. In fact, a closer examination of these concepts reveals that power acts a mediating factor which relates structurel properties, such as soan of supervision end centralizetion, to leadershio dimensions. No inquiry into the relationshin retween atructural and leadershin variahles is adequate without an exploration into the realn of power.

cne of the most astonishing demonstrations of the effects of power on the reharior of Deople who possess 1 t was provided by the work of zimbardo. In a study conducted at Stanford University, Zimhardo on his associetes used college students to simulate a orison environment. Half of the sutjects was randomly selected to serve as puards, and the other half was assigned the role of prisoners. The results were startlina. The guards quickly hecame highlv aggressive and the orlsoners rery dassive.

Tyolcally, the guards insulted the orisoners, threatened them, were physically ageressive, used instruments (night sticks, fire extingulshers, etc.) to keep the prisoners in line and referred to them in inpersonal, anonvmous, deprecating ways.... Frow the first to the last day there was significant increase in the guards' use 
of most of these domineering, abusive tact 108.1

The intense agaression and sadisw shown compelled the experimentors to terminate the planned two-week experiment after sir deys. 2

On the basis of the above findings, one may genera11ze that, given the opportunity, wan tends to actively exerclse h1s power and authority over h1s subordinates. For the sake of ethical considerations, such generalization makes the taks of delegating authority, formalizing rules and procedures, and deteralning the span of control extremely critical. Aware of 1 ts importance, administrative theorists have challenged the task of span determination throughout the years. In the past, these theorists have suggested that a narrow span 18 associated with tiahter control over suhordinates, while a wider soan is related to a decentralized supervision. ${ }^{3}$ Furthermore, some hehavioral solentlsts have prodosed that human IImitation on the span of attention 18 a major determing factor for the span of control." Cowining these propositions pp. $48-49$.

1"A P1randelilan Prison," New York Times Magazlne,

2K1pnis, "Does Power Corrupt?," pp. 33-41.

House and Miner, Meraing Management and qehavioral Theory: The Interaction netween Soan of Control and Group s1ze," p. 455: and Litterer, The Analysis of Organizations, D. 565 .

${ }^{4}$ Entwisle and walton, nonservations on the span of Control," p. "29; and M1ller, "The Maglcal Numer Sever, Flus or Minus one: Some L1mits on our capacity for Processing Information," pp. 81-97. 
with the generalization drawn on the findings of Z1mbardo, one can stidulate that, given the opportunity of a narrov span, the leader tends to exerclse more control over h1s subordinate, while, when the span is larese and therefore the leader's attention more scattered, he would have no cholce but to exert less control. Enoirical findings on this stidulation are mixed and inconclusire and not always in line witr the predictions of the hove stioulation. Jiemphill, through empirical research, suggests thot:

...there is a tendencv for the leadershio role in the larger aroup to take on a preater degree of 1mpersonal direction connected with firmess and impartiality in enforcement of rules and regulations. Subordination of memters to leader recelves areater emphasis in larger groups as ind lcated oy...less

' 11 stening to others'....

Resolution of the controversy orer span/leadershid relationship requires further research. This study 18 a response to such a need. Further explanation of the purpose of this study will clarify the direction in which this research could contribute to rulfill the need for more inquiry into this area.

\section{Importance of Leadership and Span of Supervision}

The ereat volume or what hos been written on leader-

\footnotetext{
${ }^{5}$ Hemphill, "Relations petween the size or the Span and the Deharior of "Superior Leaders'." $p .19$.
} 
ship indicates the importance of leaderahip in effectiveness and efflciency of human organizations. One can hardly exaggerate the signiflcance of leaderahio in the achlevements of social, political, and economic establishments. Since the earliest stages of human clollization, any major achievement has usually been attributed to the characteristics of the behavior of an outstanding oerson, the leader. What has not ceen accomplished by the insplration of great leaders? Peace and war, the creation of nations and their destruction are forced by them. A trief glance through history reveals that aluost anything is possihle to achleve with a proper rlend of a leader and an organization.

A great leader who is not accepted hy his followers is no leader at all. The organization, formed of those who accept the leader's command, is of equal, if not more, importance in accomplishing seemingly impossinle goals. To understand what distingulshes an effectlve organization from an inerfective one, an insight to organizational properties, as well as to leadership characteristics, is necessary. One of the earliest properties which attracted the attention of organization hullders, leaders, and scholars of the fleld was the span of supervision. In their review of 31 empiricol studies, Thomas and Plnk conclude that "... Broup size (span of subervision) is an lobortant rarlatle which should be 
taken into aocount in any theory of group behavior." more, these athors suggest that "...future research on group size should proceed more avatematically then in the past."? one such systematic inquiry to the realm of span of supervision would be to investigate the interdependence between the span of supervision and leadership dinensions.

\section{Puroose of the Study and statement of the Prohlem}

The ourpose of thls research 18 to investigate the correlation between the span of supervision and the directiveness of leadershio as specifled along the dimensions of a) initlation of structure, commonly known as task orientation, b) consideration or relationshio orlentation, and c) percelved centralization. It is also the intention of this study to deternine whether the actual hehavior of the leader along the two digensions of Inltiation of structure and task orientation 18 consistent with $h 18 /$ her expressed leadership opinion along the same two dimensions. Although no attempt 18 made to 1dentify causal relationships, the findings of this research may lead to recommendations about span of supervision or leadershid style.

Definition of the Variaties of the Research A prerequisite to the formulation of the hyootheses

\footnotetext{
FThoms and Fink, "Effects of Group size," p. 371. Ioc c1t.
} 
concerning relationshios between span and leadership properties 18 the identification and definition of relevant variables. The varianles of this study are ldentified under the two basic dimensions of structural variables and leadership varlables.

Structural Variable

Span of Supervision: span is defined as the number of sutordinates to a leader, or the number of beoble reporting to him. ${ }^{8}$ The span could be soecifled as an averape or maximum number. In this research, span 1 s derlned as "the maximum number of suhordinates subervibed at one time."

I eadershio Variables

since the ohio state leadershio studies in 1945 , the most popular and commonly used dimensions of leadership theories are two: initiation of structure (representing task orlentation of the leaderl and consideration (relationship orlentationl. 9 Due to the1r popularity, these two varlables are used here to renresent leadership styles.

In1tiotion of structure: reflects the extent to which the subervisor racilitates or derines

81.1terer, op. o1t., p. 559.

"Karwel, "A Challenge to Tradltonal Hesearch Methods and Assumptions," pp. 475-483. 
group interaction toward goal attalnment. 10 The leader does this hv clearlv defining his own role, ant by lettina his followers know what is expectoc. Sonslderption: reflects the extent to which the suberior 18 consiterate of the feelings of those under him. It comes closest to reoresentinf the "human relations" gnnroact toward group memrers.1? to to so, the leader reapros the comfort, well "elng, stetus. and contributions of the followers, 13

Structural/leaderahir Variatle Central17ation: Althouoh a structural varienle $r$ nature, ${ }^{l}$ centralization is uset here to Indicate directiveness of leadershio strle. Centralization is tefined as the regree to widch nowr is concentrated in an organization. ${ }^{15}$ It is nea-

10 Fleishran, "mhe measumedent of I eacership attitude in Industr"," D. 15.4.

11 Stogd111, Manual for Ieader Eehavior Descriotion Questionnaire - Porm XII. 5.3.

12 pleishmen, 10c. c1t. 12 Stord111, 100. 1ㅗ.

14 wape, "An axiomatic Theorv of Organizations" $p$. $293:$ Pennings, "Measure of Oreanizational structure: A Methorologlcal Note," od. Lar-7ra; Feze and Alken, "qelationshids of Centralization to other structural pronerties," 0.77 : and M111er, Landbook of Research Destan and Social Measurement, D. $28 K$.

15 M111er, 10c. c1t. 
sured along two dimensions. The first measure is "particioation in decision-making" - how much the Individual participates in decisions about the allocation of resources and the determination of organizational policies.16 The second measure of centralization 18 "hierarch; of authorlty." Th1s refers to the degree to which the organization menter particlpates in declsions involving the tasks associsted with his position. 17

\section{Hvootheses}

As noted earlier, due to Inconclusive evidence, the question of whether a relationshio hetween span and direct1veness of leadership exists has not heen adequately explored. The first rour hypotheses tested in this study have veen formulated to provide an answer to this question. HYPOTHESIS I : Span of supervigion (s) is significantly related to "personal partic1petion" as an inder of centraliza$\operatorname{tion}(\mathrm{Cl})$

FYPOTHESIS II: Span of superviston (s) 18 signififlcantly related to "hierarchy of authority" as an index of centra-

16

Hage and A1ken, op. c1t., pp. 78-79. 17 Loc. c1t. 
ilzation (C2).

FYPOTHESIS III: Span of supervision (s) 18 signiflcantly related to actual "initiation of structure" as an index of leadership as percelved ry subordinates (LIA). HYPOTHESIS IV : Span of supervision (s) 18 significantly related to actual "consideration" as an index of leadership as Dercelved by folllowers (I.2A).

Whether the leadersh1p hehavior of the supervisor 18 consistent with his personal teliefs 18 a question that is angwered hy teating the following two hvpotheses.

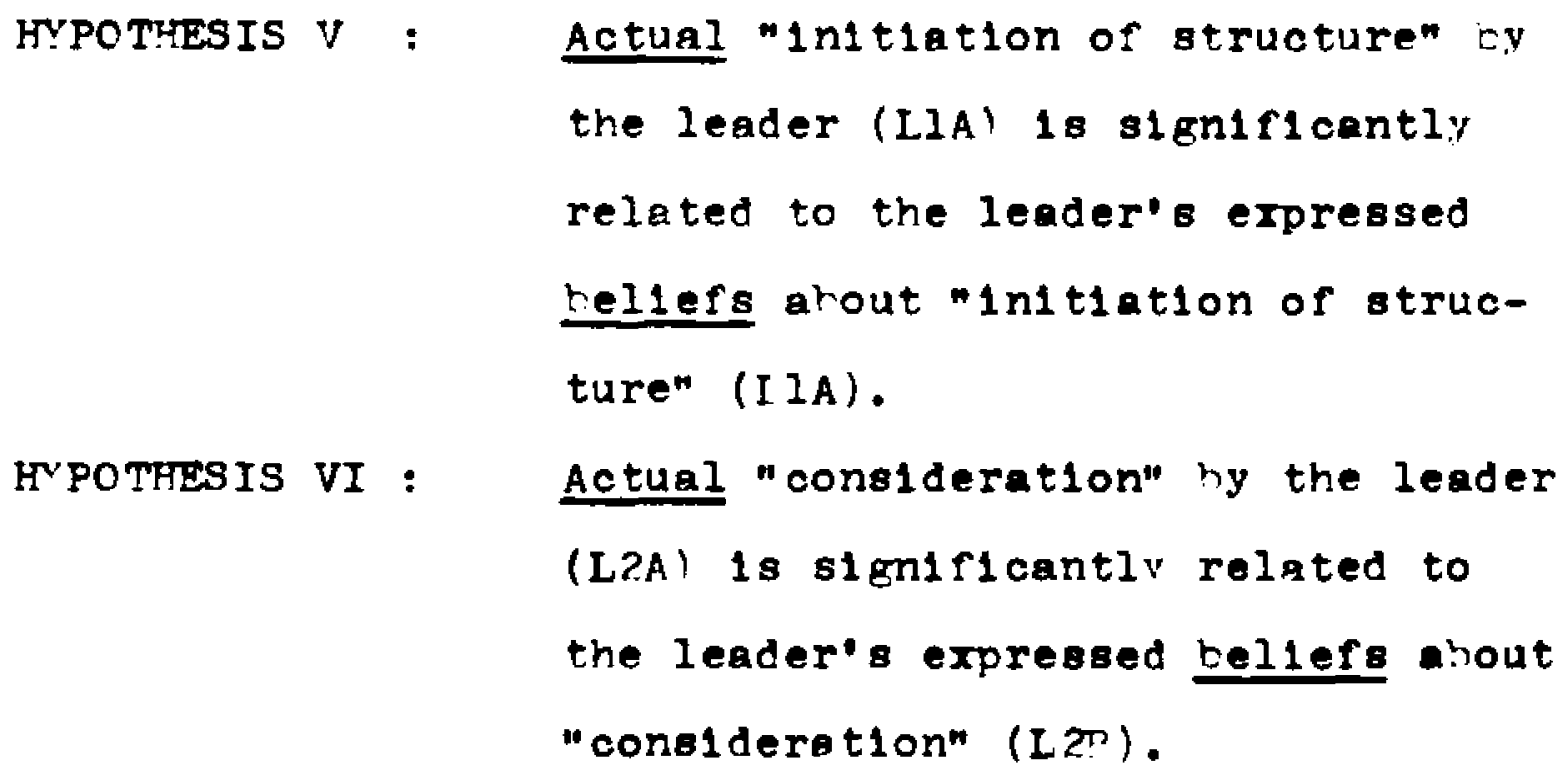

The correlation analysis determines whether posit1ve or a negative relationshid exists hetween the variarles in each hypothesis.

Scode ond Liwltations of the study Th1s study focuses on a sample of fast-food opera- 
tions in the Greater aaton Pouge area. Explanation of why and how this sample is selected is provided in the ohapter on methodology, later in this thesis. Ohviously, the findings of this study are restricted by its sampling limitations. Another 11mitation to this study is the use of perceptual data. Perceptions of actual behavior seldom perrectly match the reality of these behaviors. However, this 11mitation is common to most fleld surreys and should not hamper the validity of the study.

A third possible limitation concerns the usual prorlems associated with the administration of questionnalres. 18 Pronlems such as faked, Doorl:" thought out, or incomplete responses could result from lack of understanding of respondents w1th little education, etc. These problems have been minimlzed b." making the questionnalres shorter, rewording some 1 tems of the instruments to make them easy to understand, and increasing the sample size to compensate for unreturned or incomplete questionnaires.

The detection of correlations hetween the varlarles under study is the primary end to this paper. This research makes no atterot to detect causal relationships tetween tre varianles. Sucr a detection requires a level of sophistication be"ond that of the methodology applied in this study.

18 WL111ams, "On Administering Questionnaires in Organizational settings," op. 93-103. 
Justification for the study

Early contingency theories of leadershio dostuloted that an opt1mum leadership style for a alven organization was a function of three major forces: forces in the leader, forces in the sutordinates, and forces in the situation. 19 since then, scholars in the rield have directed thelr attemote toward verification of sienificant variaties in each of these three dimensions. 20 structural variables are among the major situational varialies that are exoected to affect leadership. Although structural oroderties and the1r leatersh10 1molications have attracted the attention of many field researchers, 21 amons these broderties, soan of subervision is one factor that $1+8$ effects on leadership still need to he further exolored. Toniricel findings on the correlation jetween the span of supevision and the leadership varianles are scarce and inconclusive. The few studies that concern themselves with such a relationship rarely touch upon the sungect, and

${ }^{19}$ Schmidt and Tannerhaum, now to Choose a Leadersh1p Pattern," p. 98 .

20 For examples of such studies see: Fiedler, A Theory of leadershid Effectiveness: Vroom, Work and Motivation; Schmint and Tannerhaum, op. c1t.: Pehlinf and Schre1shiem, Organizational Fehavior, Chapter 12: and House, "Relation of Leader Consideration and Intiation of $s$ tructure to $R$ and $T$ Suhordinates" Satisfaction," Do. 19-30.

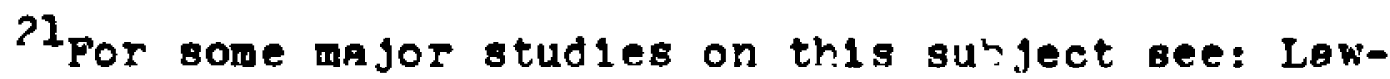
rence and Lorsch, "Differentiation and Integration in Complex Organizations," Do. 1-47; Noodward, Management and TechnoloBy: turno and stalker, The Management of Innovation: PennIngs, loc. c1t: and Here, loc. c1t. 
usually discern 1 t as an extra finding, an offshoot of the orlelnal research. Obviously, since the primary purpose of such studies differed from, and were not restricted by, the detection of such a correlation, methodological protiems inrolved in the interoretation and generalization of these offshoot correlations are hard to ignore - a fact that creates a definite need for a research which is particularly desianed to detect such correlation. As a resoonse to this need, tris study orovides some clarification on the relationship retween span of subervision and leadership properties. The rindings of this research moy lead to suggestions for organizational desion as well as for selection of the leader. At the present time, most organizational designs, and therefore the soan of supervision, are determined independently frow leadership inclinations of the supervisor. The detection of a correlation hetween these varlables means that the determination of the two dimensions can no longer take place indedendently from each other. That $1 \mathrm{~s}$, el ther the right lesder, with aporopriate inclinations, should he assigned a groub of g given size, or the span of sudervision has to te modirled to match the leader's leadership inclinations.

\section{Preview}

The following chapter oresents a selective revier of literature relevant to this studv. Chapter III descrites the research methodology, Including detalled information on 
13

sampling, measurement, Instruments, and data analysis techniques used. The results of the study and the findings are delineated in chapter IV. The fifth chapter concludes this presentation with interpretations of the findings of the research and suggestions for future studies. 
CHAPTER II

REVIEW OF LITERATURE

The relevant naterial in the literature dealing with span of supervision, leadership, and centralization is discussed in this chapter. The studies concerning each of these concepts are numerous and diverse. Since an exhaustive oresentation of the three toolcs is luoossible, the autror has heen selective in the review of dertinent materigl. Consequently, there are many buhlications dealing with this area of inquir" that are not oresented.

a central theme of this studv is the span of suoervision. lost sturies on span focus on the deterwination of optimum soans or the maximum number of sutordinates a aiven supervisor can handle. 1 trwick orescrited a epan of control with a gaximum of $\mathbf{s i x}$ people, while worthy araued for a larer span of control hecause 1 t provided a areater opportunity for Individual develobment and higher morale. Entwistle and halton notes that factors such as organization size and function arfected the soan. In turn, Porter and Lawler found a correlation retween size and norale. This chain of studies diverted

Ifrwlok, "The Manaker's soan of Control," op. 3947: Worthv, moraanizational structure and Employee "orale," pp. 1<9-179; and Entwiatle and Walton, "orservations on the Span of Control," p. 529. 
the researchers' interest to a whole framework of related structurel variahles.? Woodward and wickson, Pugh, and Phesev related first-11ne sudervisors' span of control to technology ut1lized by the flrm. The: concluded that, al though there was no "one rest" span for all situations, it seemed that the more successful organizations did utilize span close to the median of their particular production group type. $^{2}$ This fact sugaested that there misht be an optimum soan for a given work situation.

An innovat 1ve adoroach to span was brodosed $r y$ Souse and Miner. In demonstrating the existing division within organization theorr hetween management and rehavioral viens, thev use the frequentiy narallel literature on span of control and correlation of proun size as an example. This work oresents a diverse review of literature on span of supervision and its ehavioral counteroert, aroup size. It is revond the scode of this research to present a review of this article; however, the interester reader is encouraged to refer to the orlatnal source. ${ }^{4}$

${ }^{2}$ Dunnette, Hend'ook of Industrial and Organizational Psychology, DD. $1139-\pi 13$.

3 Noodwert, Industrial Oraanizations: Theory and Practlce: and Tlekson, Pugh and Phesev, "Onerations, TectnoTo: And Organization Structure: An Elolrical Reaporalspl," pD. $45-54$.

4ouse and Miner, mergine Yanagedent and pehavioral Theor: The Interaction ietween Snan of Control and Grous Size," D. $4 k \%$. 
I 1tterer brovides a list of factors influencing the span of control.' I 1mited human capahllity to handle interpersonal relationships, type of technology utilized by the organization, orkanization slze, hlerarchical level, use of Dersonal assistants, sudervision from others, discretion exercised hy sunordinates, stanllitv of environment, and configuration of the hierarchical structure are amonf the factors influencine the span of subervision. The span of control, in turn, affects the shape of orkanizational hierarchy. If an organization has road spans of control, it will have fewer levels and a "flat" structure. An organization with the same number of mem hers hut emoloving narrow spans of control w'11 have more levels and a "tall" structure. $f$

The span wight also affect, and in turn he affected $\because$, the directiveness of leadership. The remainder of this section will present relevant material in the 11 terature regarding two major caterories pertinent to this study. The followine discussion rocuses on the relationship between soan and leadership styles. Then, a review of the literature on the relationshlp between span and centralization concludes the present chapter.

5.73.

'L1tterer, The Analysis of Organizations, po. 459InId., Dp. 55,9-560. 
Span of Supervision/Ieadership

The adrocates of a hroad span of control argue that a narrow soan and the concomitant "tall" organization structure make for red tape and difflculties in communlcation: furthermore, supervisors with short spans way tend to delegate less and to supervise more closelv. thus camaging the morale. $?$ As noted earlier, evidence for and against this argument exists. ${ }^{8}$ Contrary to the evidence that supports this argument, Hemphill provides evidence that there is a tendency for the leadership role in the larger group to take on greater dearee of 1 mpersonal direction connected w1 th flrmess and 1moersonality in enforcement of rules and repulations. 9 Femphill's proposition 1mplies that wider soan is correlated to: a) a higher task orientation, and t) lower consideration on the leader's part. The interpretation of Femphlil's findings requires extreme caution due to the methodologicel limitations of his otudy. One mlght criticize h1s research desian on the ground that little control was exerted to exclude the effect of intervening varianles that could conteminate the results of his study.

THouse and Miner, loc. c1t.

$\theta_{\text {worthv, loc. c1t. }}$

9 Hemphill, "Relations Fetween the size of the span and the Sehavior of 'Superior I eaders', " po. 11-22. 
The question of whether the type of leadership sk11? needed is different for spans of different sizes has attracted the attention of some scholars in the field. After reviewing several studies, Forehand and Gilmer stated that in dealing with a larger groub, a face-to-face technique of management glves way to sumgroups within the larger unit in coordinating behavior. 10 For instance, in his famous study in the restaurant industry, Whyte discovered that as organization size increasel there was increasing difficulty in coordinating activities. ' Homans and Hemphlll found thut as groups became larger, demands on the leader mecome more numerous, more cowplex and more exacting, and the memhers of the group becane more tolerant of righly structured and directive leadership.

\section{Soan of Supervision/centralization}

As structural property, centralization, 1.e., how power is distrinuted among social positions, has been surject to extensive study by organization theorists. The f1ndIngs of an experiment conducted by Morse and Beimer suggested that centralization was related to a higher rate of production tut also to a lower rete of job satisfaction. 13 In their

10 Forehand and riluer, minvironmental Verietions in Studies of Oreanizational Behavior," pp. 2K 1 -3A?.

11, whvte, "Social structure of the Restaurant," co. $302-310$

12 Homans, The Human Group.

13 Morse and Relmer, "The Experimental Change of a Major Organizational Variable," pp. 120-129. 
communication studies, Rarelas and his associates obtained similar findings. 14 rlau and Scott's studies of asemblyline work showed that hioh centralization was associated with high routinization of tasks (high formalization), which in turn was related to hipher production, hikher productivity (efficlency), but at the same time to lower job satisfaction and higher levels of turnover. 15 There are numerous studies which suggest that higher degree of centralization is desira-le al though it may have negative effects on employee morale and satisfaction. ${ }^{16}$

Rased on the rindings of a questionnalre survey, Worthy stated that a "...'flat" decentralized organization structure calling for wide spans at the midile and upoer echelons is superlor, as far as emplovee morale is concerned, to the 'tall' centralized orsanization structure mased on a narrow span of control."17 This assertion lmplies a nerative correlation etween span and centralization. As stated tefore, in this studv centrelizotion is measured along two d1mensions of participation in decision makine and hierarch: of authority. Using the same dirensions, Pennings found a

14 Barelas, "Communication Patterns in Task-Criented Groups," po. KK9-582.

15 glau and scott, Forrel creanizations, p. 48. 16

For a review of the literature, see Hage, "An Axlomat1c Theory of Organizations," on. $289-320$. 17 fouse and viner, op. c1t., p. 455. 
negative correlation between the chief executive's span of control and centralization. The correlation between span and oarticipetion in decieion making was -.53 , and the correlation retween soan and hierarchy of authority was slightly less tut still simificant. 13 whether the findings of worthv and Pennings are contradictory, complimentery, or siobly unrelated could form the sut ject of a dehate. Iowever, hefore any further interoretation, the reader needs to know that the correlations found $5 y$ pennings were hardly sianiflcant. The controversy over predictions of most span/ centralization studies is not limited to the findings of Pennings and Worthy. Feal: studied the span of control in 574 organizations and concluded that executives with lprger spens tend to involve all assistants in decision making more than executives with smaller soans. ? Contrary to Healy"s findings, Heller and vulk studied $?^{*} 3$ managers" and supervisors' tehavior and concluded that the sharlng of decisions with sutordinates was greatest when the leader had a sagll span of control. ?l The review of 11 terature on span/centra11zation relationshio, although inconclusive, oresents a

19. The latter coerficient of correlation was - .41. See Pennings, "Measure of organizational structure: A hethodoloploal Note," D. 693.

$$
\begin{aligned}
& 19 \text { Ibld., } 0.496 . \\
& 20 \text { Healv, Executive Coordination and Control. }
\end{aligned}
$$
and situational Varlaties," Do. ?27-?41. 
consistent theme. The relationship is not as simple as it appears in the first olace. This fact justifles a more indepth inquirv into the relationshio hetween the two variatles. 
CUAPTEY III

METYCDOLORY

Th1s chanter oresents the methodolog" utilized in this research. The first part of the chapter identifles the characteristics of the work group sultatle for this study. The sample and wethod of data collection are discussed next. The thlrd part of the chapter explains the instruments use? in the research, and then, a discussion on the data analysis techniques is presented. A hrief descriotion of the pretest and the revision of the questionnalre conclude the chapter.

\section{The Twne of Work Groud Sambled}

A fiela surver technigue was selected for the purpose of this study due to the fact that it provided for more external validity in comarison with a lahoratory exoeriment. Yowever, fleld survevs commonl, present the prollem of low internal val1dity. In the real work proup, a numer of intervening variahles interact with the variarles under study and complicate the detection of "pure effect." To preserve the internal validity in a surve", the methodology should te designed to detect and reduce the contaminating effects of major intervening variables. A number of intervening factors pertinent to this study and the methods used to reduce their effects are discussed in the followine daragraohs. 
Technology and Tvpe of Industr:

Many theorlsts sugrest that the tyoe of industry and technology are vajor determinants of the span of supervision. ${ }^{1}$ another group of theorlsts argue that the type of industry and technolorv also have an 1mpact on the directiveness of leadershio stvie.? To eliminate this technolox: effect, the samole was taken from oraanizations rithin the same industry.

Organization S1ze

Porter and Lawler found that the size of organ1zations had an imnact on satisfection and 1 ts relationshio to structure (soan of subervision included). 3 Their study reveeled that, in orfanizations with more than 5,000 employees, a tall structure, therefore a narrow span, led to more sat1sfaction, while in organizations with less than 5,000 employees, higher satisfaction was related to a flat structure, a wide sian. 4 To eliminate the orkanization size effect, the arouns in the sample were selected from organizations of compararle size.

Isee: Wootward, Management and Technology: Lawrence and Lorsch, "Differentiation and Integration in Complex crganizations," pD. 1-47: and rurns and Stalker, The Menagement of Innovation.

${ }^{2}$ Dur in, I egrersh1p in Product1vity: Some Facts of Industrial L1fe: and Tausk, Work organizations.

3orter and Lawler, "proderties of crganization Structure in qelationship to Job Attitude and Eehavior," p.1232. 0.4⒈

4 House, "Mergine Manacement and Behavioral Theory," 
Occupation

The type of occupation, professional job or nonprofessional blue-collar job, could have had an 1mpact on the results of this study. Previous studies have found differences tetween professionals' and blue-collar workers' att 1 tudes and reactions towards leadership and other organizational attributes. 5 To avold the intervention of an occupational effect, the sample for this study had to he selected ron groups with a combarahle occupational structure.

Joh Level

Hulin and $\Rightarrow$ lood proposed that joh level was ar: influential dimension in the tetermination of the worker's responses. 6 several studies have orovided evidence to this oroposition.? The implication of these findings for this study was that the work grours included in the sample needed to re of compararle organizational level.

Higher-Level Ianageraent Leadership style

The actual hehavior of a leater is influenced t: the manner he himself is supervised. 8 Flelshwan found a

Fost contingency theories or leadership discern these differences in detalis. For example, see: 3chmidt and Tannerbaum, "Yow to Choose a Leadership Pattern," pp. 99-1C0. Kulin and Alood, "Jot Enlareemert, Individual Differences, and Work Responses," Dp. $41-55$.

TKornhauser, Mental vealtr of the Industriel Worker.

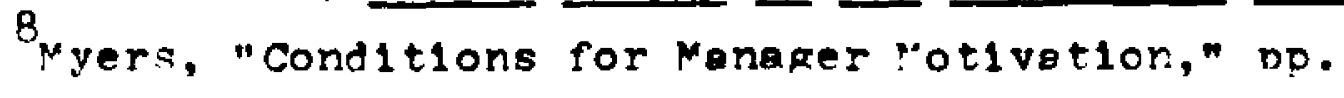


correlation 'etween the hehavior of a supervisor and that exhiblted by his nogs. 9 pe noted that men who worked for conslderate nosses were reported to he more considerate toward thelr subordinates than were men working under less considerate supervisors. A similar chain of effect was found for initiation of structure. Such an organization climate effect was reduced in this study hy selecting work groups that were somewhet insulated from higher organizational levels; therefore, the leader had conslderable independence in selecting his oum leadership style.

Personal Inclinations of the Ieader

A leader's personality tyde may have an lupact on his behavior and the troe of leadership approach he chooses, thus, on the relotionships sur ject to this study. Although randomization of the selected sample reduced this effect to some extent, by no means it could have ellminated the effect completelv. An abprodriate way to opproach this prorlem was to measure the supervisor's leadershio inclinations and to determine their relationship to his actual leadership behavior. The hypotheses $V$ and VI stated earlier were provisions emhodied in this research to accomplish euch o vurpose.

A tvpe of work group that was relatively free of all the a ove-mentioned intervening effects was found in

9 Fleishman, "Leadersh10 climate, Iuman Relation Tracking, and Sudervisorv aehavior," od. $205-222$. 
fast-food restaurants. Such a sroup performed a relatively homogeneous taek, in different stores, and was relatively 1ndependent from any larger organization. The span of supervision in these groups varied, a condition that was a prerequisite for a work grolup needed in this study; furthermore, there was a large number of such stores in the area, $a$ fact whlch allowed a heter selection of the sample.

The Samole and rethod of Date collection

This study utilized a field survev technique for the data collection purpose. A sample of work groups in fast-food oderations in the creater paton qouge area was selected. The selection of tire fast-food restaurants was rased on four criteria. These criterie, in the order of $10-$ Dortance, were variety of soan, diversitv of the trpe of business, cooberation and interest of manggement, and geographlc dispersion. Tamle 3-1 oresents the nine restaurants Included in the sample and the soan for the correspondina work eroups wh1ch ranged from 3 to 24 . The restaurants belonged to different franchised operations, and were located in different parts of the c1t\%. From eleven restaurant wanagers contacted, nine showed enthusiasm and coooerated, one was enthusiastic but quit his job before the combletion of the data gathering orocess, and one was too rusy to involve himself and is emoloyees in the research. The last two restaurants were droobed from the samole. 


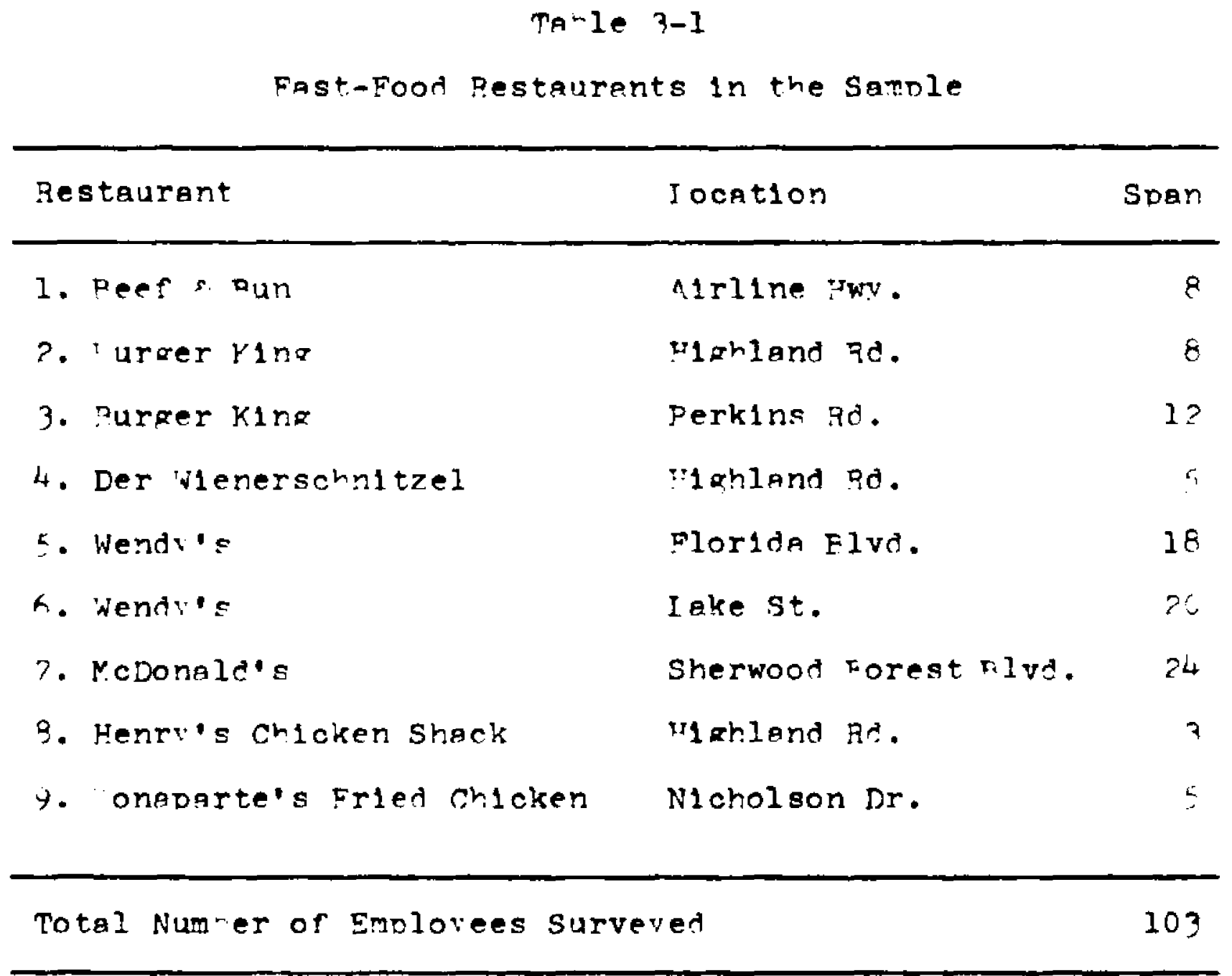


The data collection process typlcally started with. the researcher contacting the manager of the restaurant, oresenting a brief description of the study, and inquiring about the manager's interest in participating in the research. In few occasions, the manager required the permission of the regional office mefore the actual discussion of the studv. This permisaion was usually granted vertall $\%$ and the regional offlces were very helnful in securing their managers' cooperation. After the 1nterest and the commitment of the restaurant manager was secured, he was orovided with a more detalled describtion of the data sathering process, and was asker: to comblete "Subervisor odinion auestionnalre" (for samples of this questionnalre and the occompanying cover letter see Appendices $D$ and $E$ ). Then, through interviewing, the researcher determined the span of subervision for the shift under study. This method of span determinetion was chosen over the self-reporting technioue hecause in the pretest of the questionnalre and rurinr early stages of the research, the researcher 11 scovered that there was a tendency among the menagers to overstate their spen of sudervision, particularly when self-redortinr 1t. Th1s overstatement phenomenon might he due to the orestlge managers generally" attach to the sudervision of a large work eroud. ${ }^{10}$ At the The ranagement of Crganizations, oo. 371-37?. 
end of the meeting, the manager was asked to distritute some "Enployee Questionnaires" amons the employees of the shift under study. Each emplovee in the shift was asked to complete a questionnalre, and the total number of Emplovee Questionnalres collected was used to verify the accuracy of the span of supervision determined through the interview. Samples of the Employee Guestionnalre and the accompanying cover letter are found in apoendices $C$ and $F$.

To 1mprove the accuracy of the reported data and to ensure the confldentiallty, the emoloyee was asked to insert the completed questionnalre in a uniform envelope, seal the envelope, and crop it in a rallot rox. For a sample of such self-instructed envelode see Appendix ?

The Instruments

The date for this research was gathered through two Instruments: one completed by the managers and one adminlstered to the employees of the groups under study. The following sections present a descriotion of these questionnaires.

Employee Questionnalre

Th1s questionnalre was constructed to measure the directiveness of leadersh10 stile along the four dimensions of intiation of structure, constderation, personal particlpation in dectsion making, and hierarchy of authority (for a definition of the variahles refer to the "Definition of 
the Vriables' in the Introduction). The first two subscales are a modification from two of the ten subscales in the 1963 revised edition of the Leader Pehavior Deseription Questionnaire - Form XII by Ralph M. Stogd111. These two surscales were chosen over other subscales of the questionnalre due to the fact that they were the most popular dimensions used in leadershio studies, and consistently resulted in higher rellabllity as compared to other subscales. The rellanil1t: coefficlents for the intiation of structure subscale range from .76 to .89 for varlous test groups. ${ }^{11}$ The permission to use these two subscales was ortalned from the Director of Supportive Services, College of Administrative Sclences, The Ohio State University. A cooy of the letter requesting this permission and the sumsequent permission are presented in Aopendix 5 .

The last two surscales of the Emploves Questionnatre correspond to centralization and were developed by Hage and Alken. ${ }^{12}$ Th1s centrolization instrument has teen used by desioners in several empirical studies. ${ }^{2}$ Copies of the letters requesting the permission to use these subscales

11

For rellahlilty information see: Flelshman, "The Measurement of Leadership Atti tude in Industry, $p$. $15 \mathrm{~s}$ : and also Stogd111, Manual for the Ieader Behavior Questionnalre Form XII, op. 8-II.

12

Hage and Alken, "Relationshios of Centralization to other structural Proderties," Dp. 78-79.

13 IOC. c1t. 
and the subsequent permissions $t, y$ the authors are presented In Appendix H. A copy of the sunscales in the Employee Questionnalre can te found in Appendix A.

Supervisor Oplnion Questionnalre

This instrument is composed of two subscales that are basically the same as the first two subscales used in the Emolovee Questionnalre, subject to minor modifications. These su scales correspond to two su-scales of the "Leader Opinion Questionnelre" used in the ohlo state Studies. The rellability coeffiolente for an industrial-foreman test group were .70 and .79 for conslderation and inltiation of structure, respectively. ${ }^{14}$ A cop: of the subscales of tilis questionneire is attached as Appendix 5.

The Data Analysis Techniques

This section provides a trief description of the scoring formats of the instruments and the type of statistical test utilized in this stud.

Scorlng of Instruments

For Part I and Part II of the Employee nuestionnalre, as well as for the corresoonding parts in the supervisor ODlnion Questionnalre, the sum of the scores for the ten 1ters of esch suiscale constltuted the score for that

\footnotetext{
14 Fleishran, ㅇ․ ㄷt., p. 155 .
} 
suhscale (refer to the scoring notes under each scale in Appendices $A$ and $B$ ).

For Part III and Part IV, the sum of the scores for the 1tems of each subscale constituted the score in that scale (refer to Appendix a for the scoring format of each subscale 1 tem in the Emplovee Questionnaire).

Trpe of Test Ut111zed

The nature of the research. dictated the use of correlations among the variatles associated with each concept. The characteristics of the rearession analysis and the Pearson's correlation coefficlent made this method of analysis an appropriate cholce for this study. Furthermore, this type of correlation technique has teen used in previous research of this nature. In a study on the relationships of centralization to other structural properties, including span of supervision, Yage and Alken used Pearson's correlation coefficient. 15 In their studv, these researchers used the same centralization suscales utilized in this research. In h1s 1973 study. Pennings also used a Pearson correlation to correlate some structural variaties, including centrailzation. 16

15 Hage and A1ken, 10c. c1t.

${ }^{16}$ Pennings, "Measure of Organizational structure: A Methodolopical Note," pp. $68^{4}-705$. 
Regression analvsis was also used by The Oh10 State Universit:" researchers in their leadership studies. These researchers used the same leadershio sungcales apdied in this study. 1 ?

The Pretest and qevision of the Questionnalre To understand the nature of the orohlems that might ocour auring the data collection process, the questionnalres were pretested in a local fast - food restaurant. The ourpose of this pretest was not to determine the val1dity of the reliandlity of the questionnalres, hut to do a sinhlective evaluation of the problems in the data collection process. Some information on the val1d1ty and rellabll1ty estimates for varlous subscales wos orovided earlier. In hrlef, the pretest led to several conclusions. In the first olace, the su'jects involved in the data collection had no oroilem in understanding the 1 tems of the questionnalres, or in relating then to their working environment. In the secont place, some suggestions for the improvement of the layout of the Fmplovee Questionnalre emerged. The "Revised Emolovee Questionnalre," as shown in Appendix C, presents these lavout inorovements. These modifications were In addition to the initial revisions pade to adad the

17ple1shman, ov. c1t., DD. 153-158. 
orleinal aubscales to the ourpose of this study. The initial revisions are already reflected in the questionnalre subscales In Aopendices $A$ and $A$. A final conclusion was that no complication arose from the use of the "Sudervisor Cpinion Questionnalre," Aboend $1 x$ D. The revised questionnalres in ADoendices $C$ and $D$ were used for data collection in the rield. 
CPAPTER IV

\section{STATISTICAL ANAIYSIS}

The results of the statistical analysis ore reported in this chapter. The chanter regins with an introduction to the anolvsis techniques utilized in the research, 1.e., correlation and regression analvs1s. Some characteristics of the sample are then alscussed. Next, correlation coefflclents are oresented for hoth focal relationships, reloted to the six major hvoothoses in Chadter I, and peripheral assoclations which inclure classiflcation variables. The focal relationshins are further investigated through visual examination of scattered तlagrams and fitted regressior lines, and through analysis of the regression results. To conclude the chaoter, a sumary of statistical results $1 \mathrm{~s}$ provlded, and then the results are further summarlzed by hypothesis.

\section{Correlation and Rearession Analvsis}

Correlation Coefficient

As noted in chapter II, the nature of this study recommended the use of correlation and rearession analysis techntques. Amona many measures of association, the correlation coefricient is the most conventional one. Its main odvantage is thet, since it 1 s used so frequently, one soon gets an intultive 1dea of what is atrong coefficient and 
what is a weak one. 1 In the simple inear regression, the dato analysis technique ueed in this study, the correlation coefficlent meesures the strength of linear relationahips between two varianles. It "tellg us whether or not it is reasonatle to say that there exists a linear relotionshio (correlation) hetween $x$ and $y . n$ ? The most widely used coefricient of correlation is the pearson product-Moment Correlation Coefflolent, and is desionated wy the letter $r$. $^{3}$ The value of $r$ ranaes from zero, indicating that the two variables ( $x$ and $y$ ) are unrelated, to one, representing a Derfect correlation between $x$ and $y$. The values of $r$ closer to one reflect more relatedness, and the values of $r$ closer to zero represent less association. 4 The direction of the relationship $1 \mathrm{~s}$ denoted $h y$ a valence; $1 . e ., \mathrm{r}$ may be elther positive or nerative. A positive correlation is indicated by $a r$, and a nerative relationshid is indicated $r y a-r$. In addition to the dearee of relationship (r) and 1 ts direction $(+$ or -$)$, the probabli1tv that the relationship wight - due to chance (P) olso needs to he specified. p. 402 .

Is1mon, Bas1c Research Methods in Soc1al Sclence, 'Perles and Sul11van, Freund and W1111ams' Modern Business statist1cs, p. 309.

3 Meyers and Grossen, gehavioral Researoh, p. 194. 4 Ib1d., p. 194. 
Other 8 tatistios in Regression Analya1s

The correlation coefficient 18 an 1mportant statistic, and frequently a surficient one, if the researcher's intention 18 IImited to the detection of the degree and the direction of association. However, commonly the objective of many scientific investigations is to make predictions. In this case, the relationship between known quantities and quantities to be predicted are expressed or mporoximated in terms of mathematicol equations. The simplest and most widely used form of mathematical equation is the linear equation of two varlahles $(y=a+b x)$. Ilnear equations are popular in research "not only hecause there exist many relationships that are actually of this form, but also hecause they often provide close approxlmations to relationships which would otherwlse be difficult to describe in wathematical terms." In addition to the coefficient of correlation, a linear regression model is represented by some other statistics. The Coefficient of Determination, $\mathrm{R}^{2}$, represents the proportion of the total variation, in data, which is explained by the regression model. $\mathrm{R}^{2}$ ranges from zero to one, reflecting no predicterility to complete prediotalility of the regression equation, respectivelv. A presentation of $\mathrm{B}^{2}$ should be followed by an F-statistic, determining the pro-

t1cs, p. 346 .

$5_{F r e u n d}$ and W1111ams, Elementary Businese Statis- 
bablilty of the opproxlmated regression being different from zero.

Steps in Determining the Association Retween Varianles

In brief, to examine the association between two varlables, the following steos are usually followed:

1. Prellminarv Model Building.- At this atage the researcher 1dentifies the variables and, 1deally, conceptualizes a regression function explaining each reletionship.

2. Correlation Matrix Formation.- Th1s matrix is formed of correlation coefficlents and corresponding probablilties for all possinle relationships between varlables. Such matrix is typlcally produced by using any of varlous computer programs avallable. At this step the researcher examines the matrix and selects the statistically significant correlations of interest.

3. Scatter Dlagram Plottlng.- Such a diagram 18 plotted from the ohserved date and can he employed to sugges $t$ some tentative regression models. 6

4. Model qevision.- Occasionally, the original modela formed from the first and the third steps asove are revised by altering mathematical relationghipo. The

Gostle and Mensing, Statistics in Researoh, p. 166. 
criterion for 1mprovement of the model is the selection of a higher $\mathrm{R}^{2}$ which 18 statisticaliy signiflcant.

The four steps descrined hove provided a frame of reference for the sequence of the analysis process used in this research.

Limitation of Correlation and Regression Analysis

In using correlation and regression analysis, the researcher should he aware of the shortcomings of these techniques. The strongest limitations of linear-regression analys1s are caused by 1 ts underlying assumptions. Inearity of the relationship, unimodal and normal distributions, and continulty of varla'les are some of these restrictive assunptions. ${ }^{7}$ However, as noted in the prevlous chapter, these $11 m i$ tations should not he taken as a hindrance, and in fact they are not, since regressions are commonly used in studies of this nature. The linitations, of course, restrict the interpretation of the findings.

Some of the l1mitations of the regression analvals are inherent in the nature of the technirue and can not be avolded. However, there are some 11mitations that can te reduced by lmoroving the sempling procedure. The following

7Meyers and Grossen, op. c1t., op. 202-204. 
part describes the sampling procedure for this study and some considerations which led to the improvement of the statistical significance of the results.

\section{Choracteristics of the Samole}

Although normaliy the strenpth of a relationship 18 not affected by sample size, the judgement of whether or not there is a relationship 1s. In other words, by choosing a larger sample, the researcher could decrease the probah111ty of obtaining a relationship by chance, therefore, increasing the statistical algnificance of the predicted correlation. 8 sample size determination, particularly for correlational studies, is a difflcult but critical task because, If the samble is not large enough, the statistical sienificance of the estimated correlations will re low or even nonexisting. As a general rule, more than 50 observations are needed to make a simple correlation a meaningful one. 9 In this studv, the total of 103 enoloyees of nine rast-food restaurants were included in the sample (for the criteria for sample selection refer to the aection on sampling in Chapter III). From the total number of 103 ques-

\section{Bsimon, op. c1t., p. 4r?.}

9 The minizut sample size of 50 was recomended by moth Dr. Part Forthing of the Departaent of Experimental stat1st1cs, Isll, and Dr. Janet Fowler of the quantitative-Methods Department, ISU. 
t1onnalres distributed, 94 of them were completed and returned. The high regponse rate of 91 per cent $(94 \div 103=$ 91\%) was due to the careful data collection procedure and frequent follow-ubs by the researcher. 10 The large number of observations included in the sample, almost doulle the minimum number of 50 onservations needed, Improved the statistical sisnificance of the estimated correlations (refer to Appendix I, the correlation matrix, for very low probebilities related to correlation coefficients indicating very high level of statistical slgnificance).

Ta'le 4-1 presents the ample characteristics in terms of mean score and the range for varla-les under study. The average span for the sample was 11.4 and the span ranged from 3 to $2 l_{4}$. The mean score for initiation of structure expressed by managers was 45.2 with the range of 39 to 49. The scores for managers' expressed consideration averaged to 40.6, ranging from 32 to 45. The averages and their respective ranges for some classification varlahles in the supervisor Opinion Questionnalre are also presented in Tahle 4-1. Scores for percelved (actual) initiation of structure, cal-

10 The actual number of questlonnalres distributed was 123 and the total number returned was 113 . However, one of the supervisors quit his joh hefore suhmitting his questionnalre, a factor which led the researcher to delete natch of 19 emplovee questionnalres assoclated with thet supervisor. This deletion was necessary since incomplete arrays of data could not he used for the analysis. 


$$
\text { Taine 4-1 }
$$

Characteristics of the Sample

\begin{tabular}{|c|c|c|c|c|c|}
\hline Varlable & Corte & Mean & M1n1 שum & Max1mum & $\begin{array}{c}\text { Range } \\
\text { of } \\
\text { value }\end{array}$ \\
\hline Spen & s1 & $11.4^{9}$ & $?$ & 24 & 21 \\
\hline $\begin{array}{l}\text { Expressed Inltiation } \\
\text { of structure }\end{array}$ & I IP & $4=.25$ & 39 & 49 & 20 \\
\hline Expressed Consideration & I PP & $4 r i^{n}$ & $3 ?$ & 45 & 12 \\
\hline Manager Ace & $\because A \cap E$ & $29 . .^{b}$ & $2 ?$ & 42 & 20 \\
\hline $\begin{array}{l}\text { Maneger Experience } \\
\text { in Present Jch }\end{array}$ & VINJP & $5.4^{3}$ & 1 & 18 & 17 \\
\hline $\begin{array}{l}\text { Nanager's cther work } \\
\text { Exnerlence }\end{array}$ & MEXP & $51.3^{n}$ & 0 & 10 & 1 \\
\hline $\begin{array}{l}\text { Actual (Percelved) } \\
\text { Int tiation of Structure }\end{array}$ & 114 & $41.6^{c}$ & 15 & 50 & 25 \\
\hline $\begin{array}{l}\text { Actual (Percelved) } \\
\text { Consideration }\end{array}$ & I $>\Delta$ & $37.7^{\mathrm{c}}$ & 21 & ar: & 29 \\
\hline $\begin{array}{l}\text { Centralization: Per- } \\
\text { sonal Consideration }\end{array}$ & $\mathrm{Cl}$ & $8.8^{c}$ & 4 & 20 & i \\
\hline $\begin{array}{l}\text { Centralization: yier- } \\
\text { archy of authorit" }\end{array}$ & $c^{3}$ & $13.5 \mathrm{C}$ & a & 20 & $1 ?$ \\
\hline Emplovee Age & $E A: F$ & $? 1.1^{\mathrm{c}}$ & 16 & {$[1$} & $3 i$ \\
\hline $\begin{array}{l}\text { Emplovee Exderignce } \\
\text { in Present Job }\end{array}$ & EINJF & $1.4^{\mathrm{C}}$ & $r$ & 16.7 & 16.7 \\
\hline
\end{tabular}

a. Average for restaurants $(N=9)$

b. Average for restarant Managers $(n !=9)$

c. Average calculated from emblovee responses; $(\mathrm{N}=9 / 4$

d. Expressed in vears 
culated from Employee Questionna1res, averaged 41.6 and ranged from 15 to 50 . The mean score for actual (perceived) consideration, from the same questionnalres, was 37.7 with the range of 21 to 50 . The soores for the flrst dimension of centralization, participation, averaged 8.8 with the range of 4 to 20 . The scores on the second dimension of centralization, hierarchy of authorlty, yielded the mean of 13.5 with the range of 8 to 20 . The means and ranges for some classification varlahles extracted from the Emplovee Questionnalres are also orovided in Tarle 4-1.

There were $A$ male managers and a female manager in the restaurants included in the sample. of 94 employees who completed and returner the questionnalres, 57 were female and 27 were male. The num er of full-tlme emplovees was 49 and there were 4 ? part-time erployees in the somple. These classification characteristics and the mean scores presented in Tarle $4-1$ could lead to some generalizations, although limited, about the sample.

Correlation Coefficient Statistics Correlation coefficient is mensure of association between two variables. The ahsolute value of the coefflclent represents the strength of the relationship, and ranges from zero to one, indlcating frow none to perfect correlation respectively. The valence, the $s 1 \mathrm{gn}$, of the coefficlent identifies the direction of the association. A 
positive coefricient indicates that the two variavies increase and decrease together, while a negative coefficient represents the fact that, if one varlable increases, the other will decrease and vice versa.

The correlation matrix is a tatie which includes all correlation coefflcients and their respective prohab111ties of being estimated by chance for all possible polrs of variatles. Append1x I presents the correlation matrix for all variamles in this research. Under each correlation coefflolent, the provility of the coefficient helng caused hy chance, its level of signiflcance, is glven. For the purpose of analysis, the correlation oftix in Append1x $I$ was divided 1nto two matrices. Taile 4-2 presents a correlation matrix for major variables used in the six focal hypotheses whlch gave direction to this research (see the relevant section in Chapter I for the statements of the hypotheses and the varlables included). The remalnder of the variaties and their correlation coefficients form another correlation matrix presented in Taise $4-3$.

Correlotions of Major Voriarles

Correlational analysis of 94 arrays of deta resulting from the sample detected $a+.22$ correlation between span of supervision and exoressed inltiation of structure, a correlation that was $81 \mathrm{gnificant}$ at $5 \%$ level. The positive sign of coefflcient suggests that the larger the span 


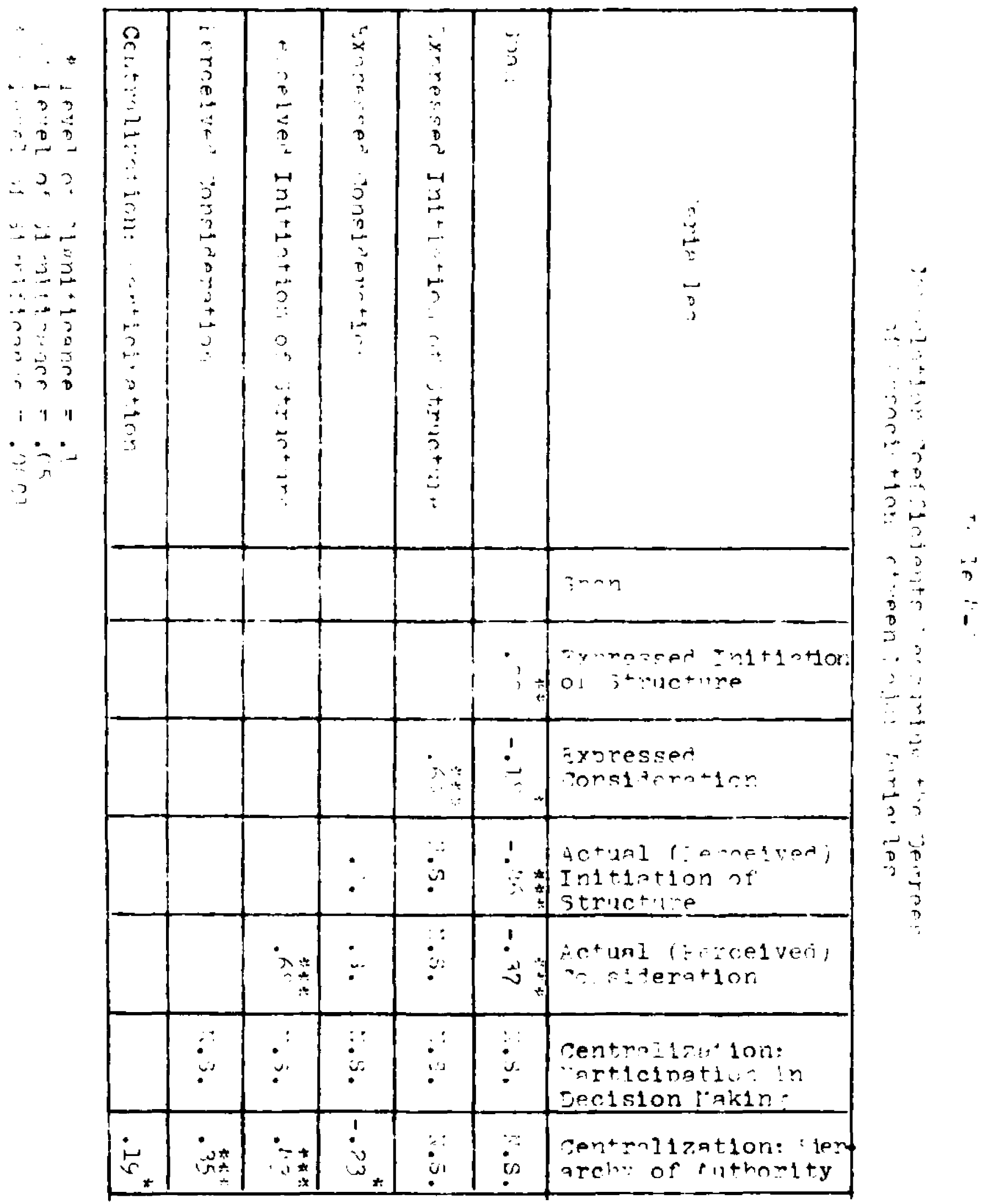


the more a manager was inclined to prescribe inltiation of structure, and vice versa. A -.18 correlation coeffleient for span and expressed consideration suggests a low but significant negative relationshio retween the two variahles. Span had 1 ts strongest correlation with actual (perceived) initiation of structure indicated by emplovee. A relatively strong negative correlation of $-.4 \%$ was highly signiflcant at .0001 level, prodosing that the wider the span the less initiation of structure was bercelver by the emoloyee. Another relatively strong negative correlation existed between span and actual (percelved) consideration. Th1s correlation was also hlghly sianlfleant at .0001 level and suggested that the wider the span the less consideration was percelved by the employees. This study yielded no significant correlation retween span and the two dimensions of centralization: personal participation and hierarchy of authority.

Expressed intiation of structure was found to te positively and significantly related to expressed consideration. The correlation coefficient of .69 was sleniflcant at .0001 level and led to the interpretation that the higher the expressed intiation of structure, the higher the consideration. Since these two dimensions were subscales of the same Instrument and the surscales had proven to te Independent in frequent teating, one may conclude that the peculiar setting or this study caused such a correlation. Th1s 18 sue will be further discussed in the next chapter. No signiflcant 
correlation existed hetween expresaed inltiation of structure and actual (percelved) initiation of structure, actual (percelved) consideration, or the two dimensions of centra11zation.

The analysis did not detect any significant correlation jetween expressed consideration, on one hand, and percelved initiation of structure, percelved consideration, or personal participation, on the other hand. Exoressed consideration had a -.23 correlation with hierarchy of authorlty as a measure of centralization, and the coefficient of correlation was sianificant at .10 level. This negative correlation suogests that the higher the percelved hierarchy of authorlty the hipher the exoressed consideration by the manaser. 11

Four wajor varianles in the Emplovee Questionnalre were percelved initiation of structure, percelved consideretion, personal participation, and hierarchy of authority. The rirst two variales were commonly used in many leadership studies, while the latter two varlatles represented two dimensions of centralization. All four variacles were utilized to measure the directiveness of leadership style. Percelved inltiation of structure and percelved consideration

11 To clarify the nature of this correlation, the reader may find it helpful to refer to $A$ ppendix $B$ for the scoring formets of the two scales. 
showed a strong positive correlation of .68, a coefficient that was highly signiflcant at .000l level. These varlables represent two dimensions of the same subscale in the Employee Questionnaire, and correspond to respective varianles in the Supervisor Coinion Questionnalre. As noted hefore in this analysis, the two variatles in the latter questionnalre also showed a strong positive correlation of .69 which was signiflcant at. 0001 level. The strength, significance, and, especially, proxinit. of the two correlations in both questionnelres is astonishinf. The close oroxinity of the two coefficients of correlation not onl: deplcts the reality of the estimated correlation, hut also 1 ts accuracy. As noted before, since the two varla les represent two independent subscales of the same scale, their correlation could he due to the particular situational characterlstics which prevalled in this research. These characteristics are discussed in the next chapter. Percelved initiation of stricture was not Blgniflcantly correlated with personal barticipation, rut it had a significant relationshio w1 th hierarchy of euthority. The correlation coefficient of .43 , which was signif1cant at .0001 level, revealed that an increase in percelved hlerarchy of authorlt: was accompanled by on increase in percelved initiation of structure.

Percelved consideration was not found to be signiflcantly correlated to personal particlpation as a dimen- 
sion of centralization. However, the research detected a statistically slenificant correlation or .35 retween percelved consideration and hierarchy of authority as the other. measure of centralizotion. This correlation, which was siennificant at .0001 level, indicated that an increase in perception of hierarchy of authorlty was assoclated with an increase in percelved consideration. Two measures of centralization, hierarch: of athorit: and personal porticlpotion, had a relativel: low positive correlation of .19 . This coefficient was statistically sionificant at . In level but not at .05 . The statistical sirnificance of this coefflclent was relatively lower than that of other detected correlations.

Correlations petween Major "arlables and Classification Varlables

Correlations between dalrs of varlahles composen or a major varioble and a classification variahle are presented in this sepment of the chedter. The classification vario les considered in this presentetion include onl $\because$ the ones with continious nature. The nature of correlation and regression analysis restricts the researcher to the ut1lization of the data obtained from continuous scales. ${ }^{2}$ Due to this mestriction, three discrete varia'les were separated

12. qefer to the discussion on 1101 tations of the correlation and regression analysis at the heginning of the chapter. 
from other classification variables and will be discussed exclusively in the next nart of this analysis. These thretexcluded varlables were manpger's sex, erployee's sex, and employee's full-tine/part-t1ue emplo:ment status. mable $4-3$ oresents a matrix of correlation coefs 1cients for patrs of varlaties composed of a major and classification varlable. The major varlanles considered are the varionles included in the six focal hrootheses of the research, with the exception of suan of supervision. These var1a les identif" the columns of the metrix. Classification variales, which identif: the rows in the matrix, were additional variales that were incorporated in the questionnalres for the surpose of acquiring some demographic information on the sample. The additional data collected orovided for the analysis and interpretation of associations supplementary to the examination of core relationships which formed the focal intention of this research. A rief investigation of the correlations oresented in ta-le $4-3$ provides further insight into the nature of assoclations. However, the analysis presented in this part is considered peripheral; therefore, subject to less attention.

The manager's age was positively and significantly reloted to foth expressed inltiation of structure and expressed consideration. The correlation coefficlents were .49 and .66 , respectively, hoth signiflcant at a .001 level. 


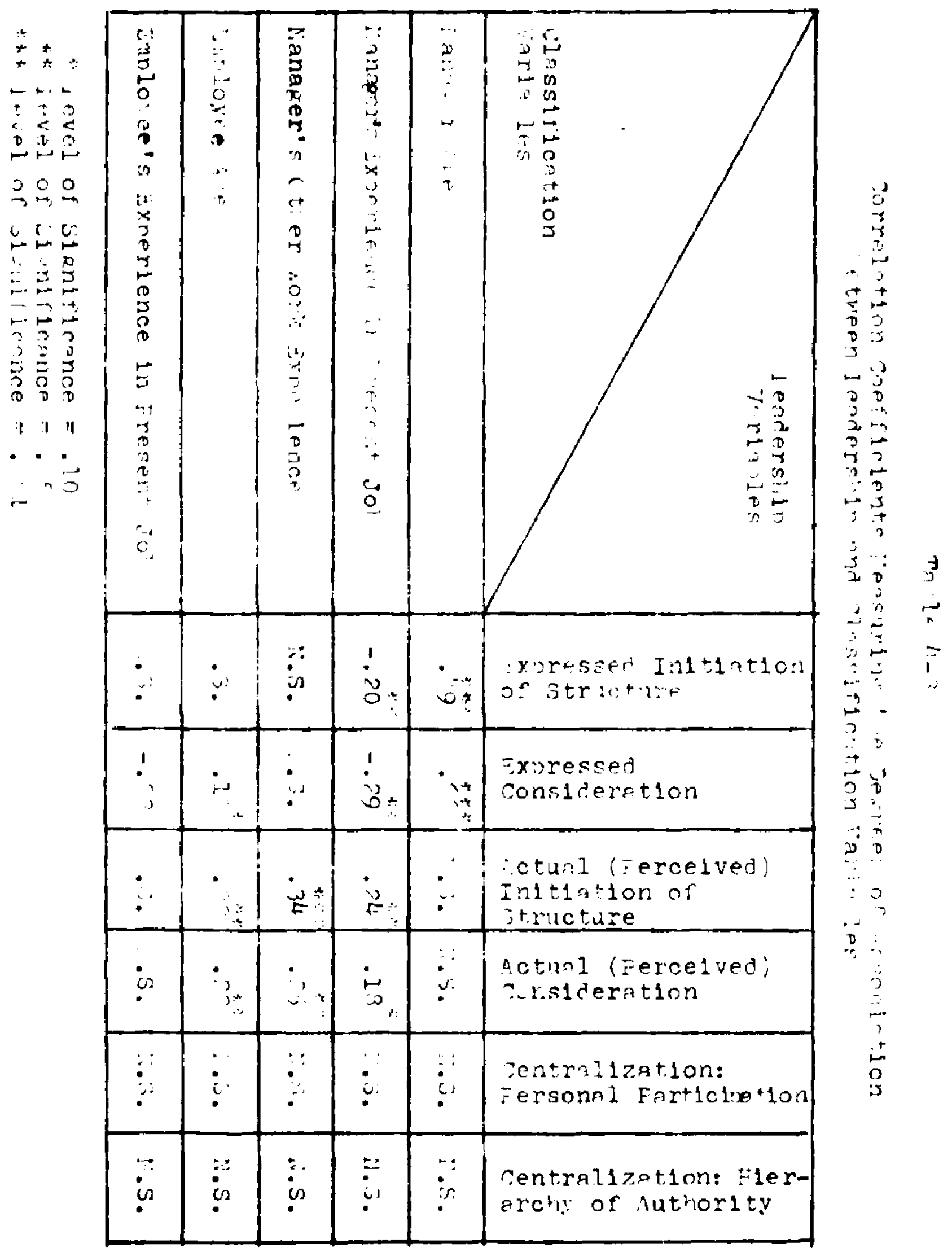


Al though older managers expressed both higher initiation of structure and higher consideration, these traits were not consistently percelved by emplovees. This is reflected in the fact that no significant correlation was detected between manager's age and actual (percelved) initiation of structure or actual (percelved) consideration. The manager's age was nelther sienificantly correlated to any of the two measures of centralization.

The managers who worked in their present jois for a longer perlod exoressed noth less intiation of structure and less consideration. The oorresponding correlation coef flclents of -.20 and -.29 were noth statistically significant at .05 level. On the contrarv, these managers were percelved to exercise more intiation of structure ( $r=.24)$ and more consideration $(r=.18)$. The first coefflcient was s1gnificant at .05 and the latter at $(.10)$. The manager's experience in the present joh had no statistically significant relationship to elther dimensions of centralization. The manager's work experience in other johs was not significantly correlated to $h 1 s / h e r$ exoressed inltiation of structure or consideration, hut had positive correlation to percelved Initiation of structure $(r=.34)$ and consideration ( $r=.25)$. The correlation coefficients were both statistically signiricant, the former at .001 level and the latter at .05 level. No slgniflcant correlation was detected retween the manager's 
other work experience and elther varlables associated with centralization.

The analysis of the data revealed no "major" correlation hetween employee's age and any of the core variables. The only statistically significant correlations were found to be between this variable and expressed consideration (low $r=.17$ was significant at .10 level), actual initiation of structure and actual consideration (both $r^{\prime} s=.22$ signiflcant at .05 level). The employee's time spent in the Jo' had a correlation of -.23 with expressed consideration, a correlation signiflcant at . C5 level. No other statist1cally significant correlation existed between the emplogee's experience in the job and any of the mojor leadership varlables.

The previous analysis excluded three discrete varlables used in the studv, 1.e., manager sex, emplovee sex, and emplovee full-time/part-time status. The following is a trief discussion on the nature of the associations of these variables.

Discrete Classification Variables and Their Relationships to other Variables.

The discrete nature of the data pathered on manager sex, emplo'ee sex, and emplovee full-time/part-time status did not allow a correlational analysis between any of these variables and any other varlasle. However, this ract 
did not rule out the possitility that a classification of the data to varlous categorles of each discrete variable could lead to the detection of ietter correlations between variahles within each caterorv. In fact, when on the tasis of emplovee sex, the existing date was divided into two grouns, the size of the coefflclent of deternination for the regression between derceived inltiation of structure and span in the male group dounled (compared to the slze of the similar coefficlent when no sex classification was used). 13 of the three discrete varlables rentioned, the employee sex was proven to he the most appropriate hasis for classificetion of the original data. The manarer sex did not orovide a good basis for caterorizing the data since there was only one female manager in the samnle. Nelther could the "asis of employment, full-time or part-time status, be effectlve1y used for classifying the data. The reports on the regresstons on classifled data are presented in the next section of this analysis. Further discugsions on such classifications w11 be oresented within the rramework of each independent regression model. These regression models were developed from the wajor relationships presented in the $81 x$ focal hypotheses of the research. The following section provides firther insight into the nature of these associo-

13 For further information refer to the analysis on the first two relationships in the next section. 
tions.

Purther Analvsis of tocal Assoclations

The earlier analvis of correlation coefficients, extracted from the correlation matrix, explained the nature of associations between specific variables; $1 . e .$, it determined the strength and the direction of associations. However, further clarification of the nature of these associatlons could he achleved by examining the scatter diagrams and the results of regression analysis. The following section presents more in-depth exploration into six focal relationships between the varlables under study. The section begins with the examination of the scatter diagrams, fitted regression lines, and the respective regression models for the two significant relationships found during tre previous correlational analysis. Wurther improvements on each regresston model are also discussed. A classification of the original data nased on the emplovee sex led to netter statistical predictions. The luproved results are provided and discussed brlefly. The final section of this part of the analysis presents the scatter diagrams for the non-signiflcant correlations. This provision alds the reader to visually verlf: the lack of Ilnear relationshios between corresponding varlahles.

Relationsh1p Retween Actual (Percelved) In1tiation of structure and Soan of Supervision 
Figure 4-1 presents a satter diagram for the span of supervision and the percelved inltiation of structure. This diagram gives a visual presentotion of the dispersion of the data for the two variahles. The horlzontal axis measures the values of the soan, ranging from 3 to 24 , and the vertical axis reoresents a scale which measures the values corresponding to actual (Dercelved! Inttiation of structure. The distribution of the data polnts on the diagram reconfirms a negative correlation hetween the two variahles. As the span increases, the values jove from the left to the right on the horlzontal axis, the corresponding values for the actual (percelved) Int $1 \mathrm{a}+1$ on of structure decrease, 1.e., more concentration of the data gt the lover portion of the diaprem occurs. Flaure $4-$ ? dedicts a fitted rerression line which reoresents the variation of the date. A mathematical estlmation of the intercetion and the slope of this line 15 provided in Tatle $4-1 /$ along w1th other results of the regression anglysis ietween the two variarles. The coefficient determination of . Pl was statiatlcall sionificant at. 0001 level.

As mentioned erore, a classification of the ortGinal date on the uesis of emplo:ee sex proved to laprove the regression results. Flgure $4-7$ presents the scatter diapram showling the association of the two varlables for nole emplovees. The reader could visually verify a clearer 
[1:12: $1:-]$

Scatter Dlaprat for snan of Sudervision and Actual Initiation of structure

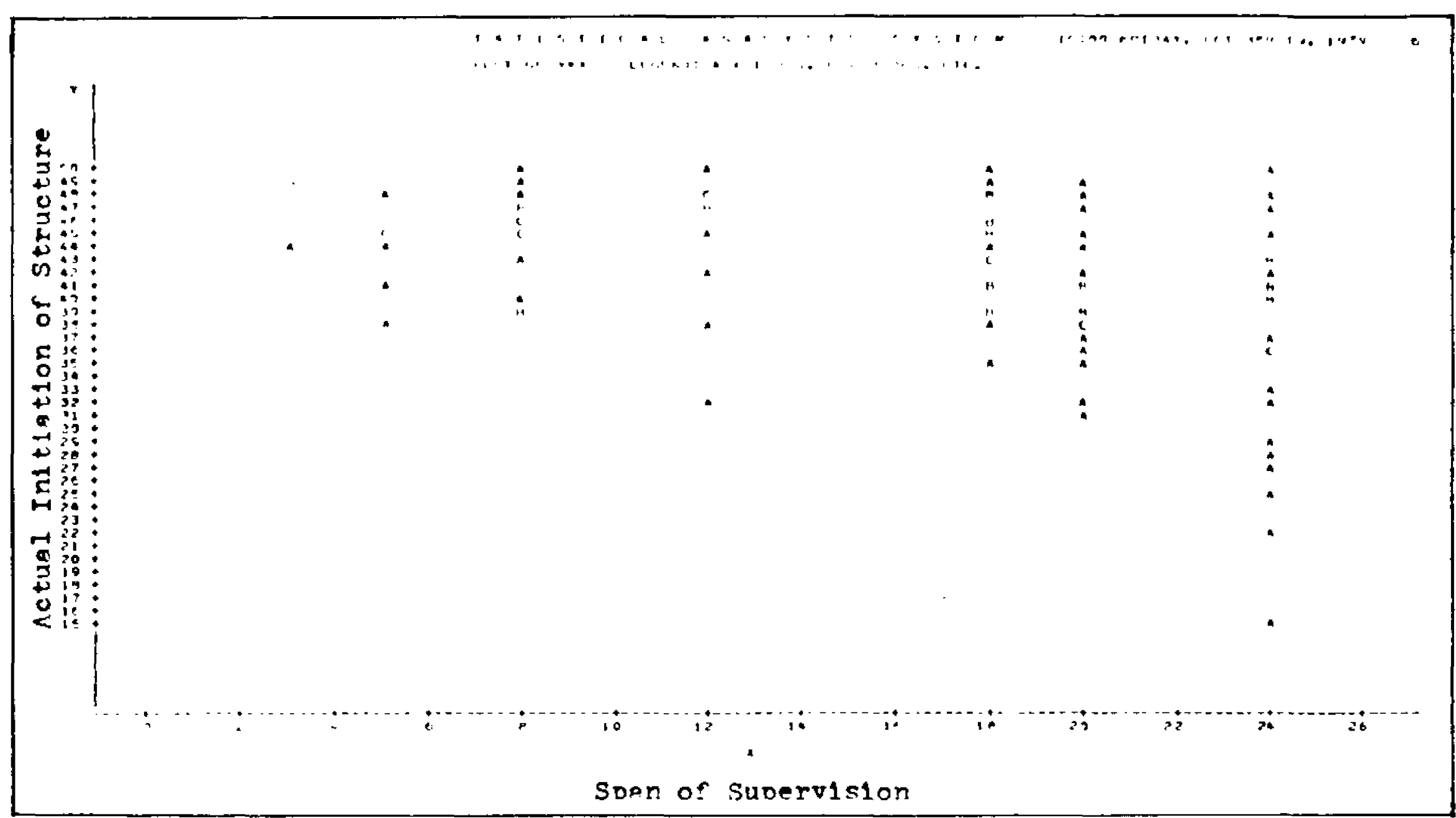




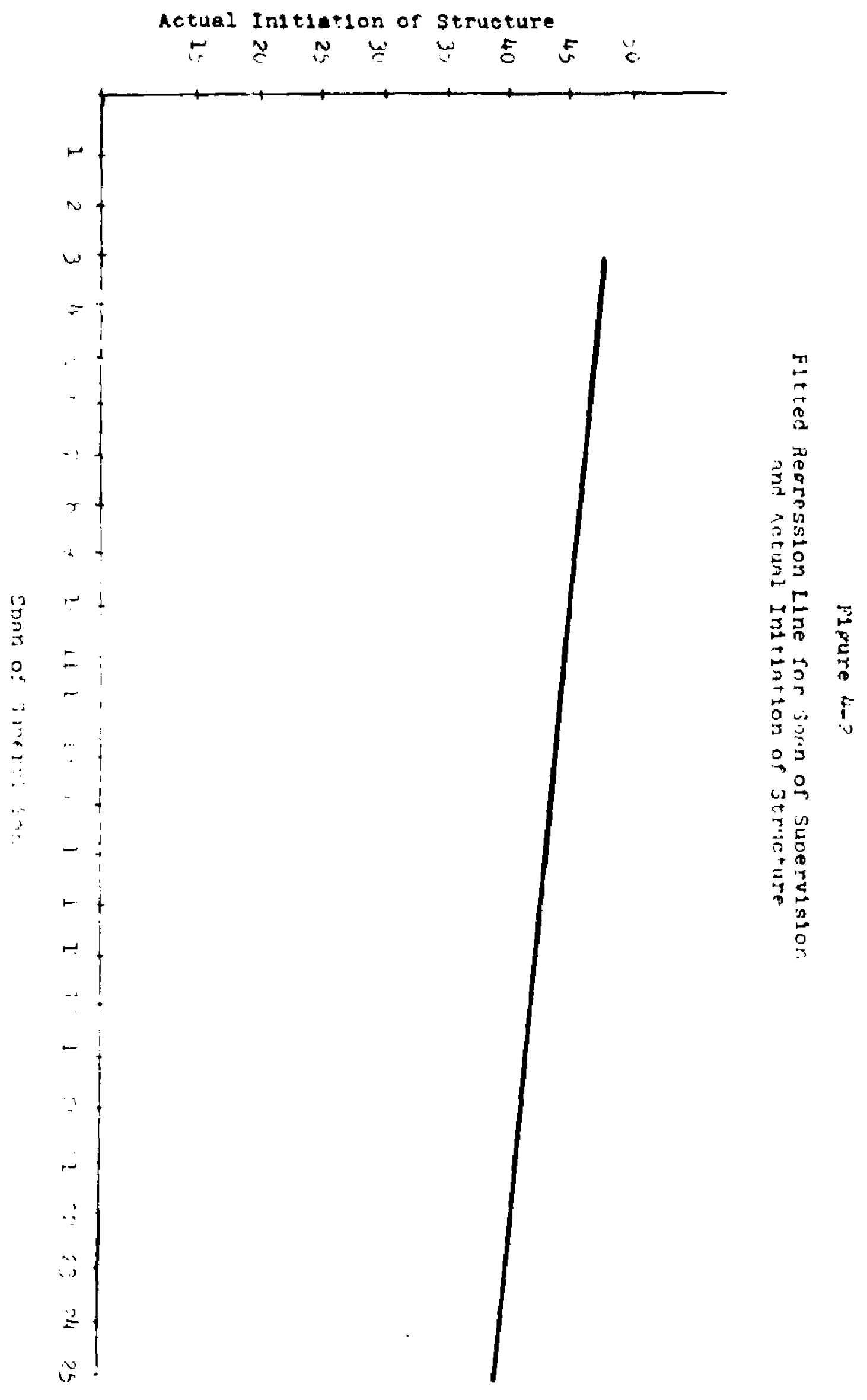



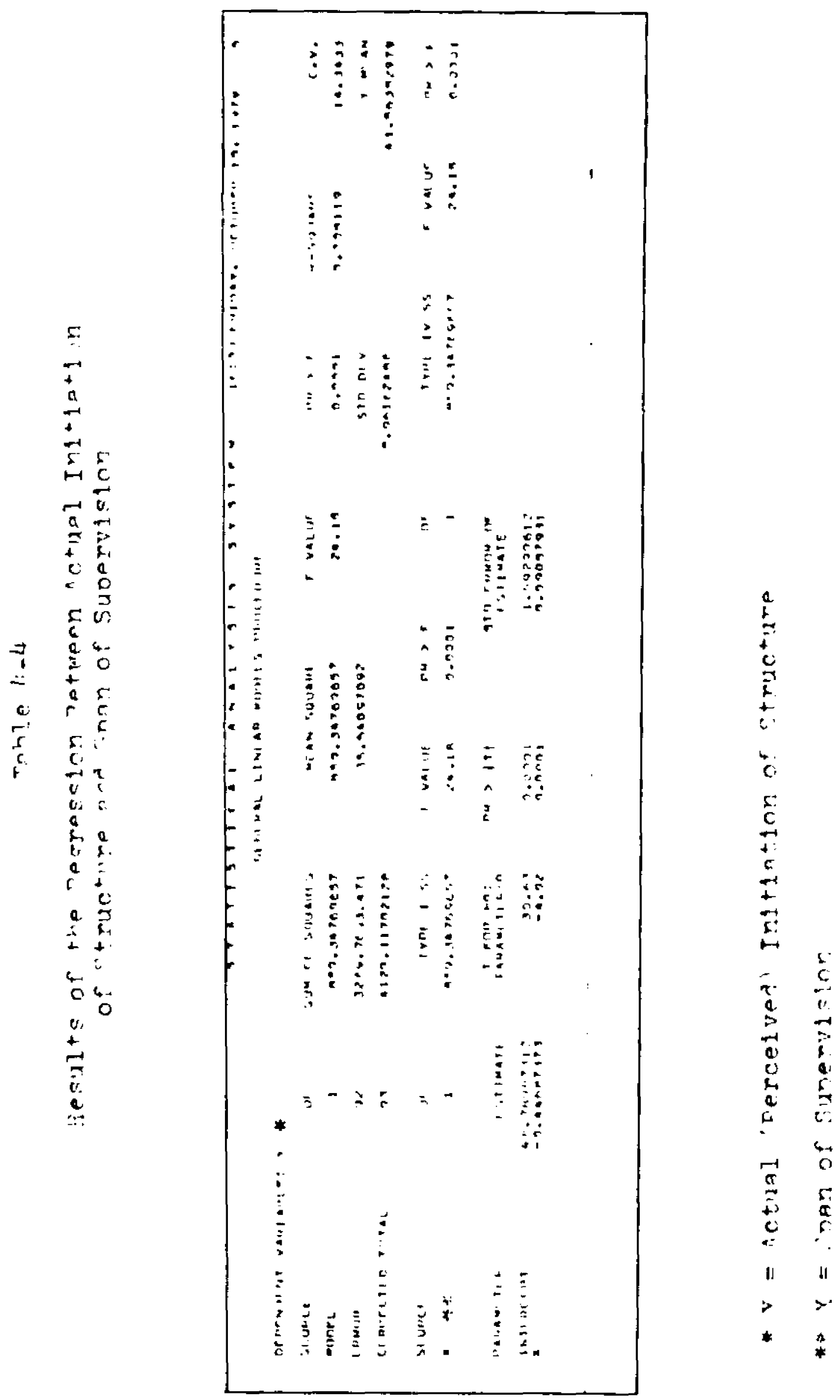
Figure 4-3

Scatter DIagram for Span of Supervision and

Actual Initiation of Structure (Male Employees)

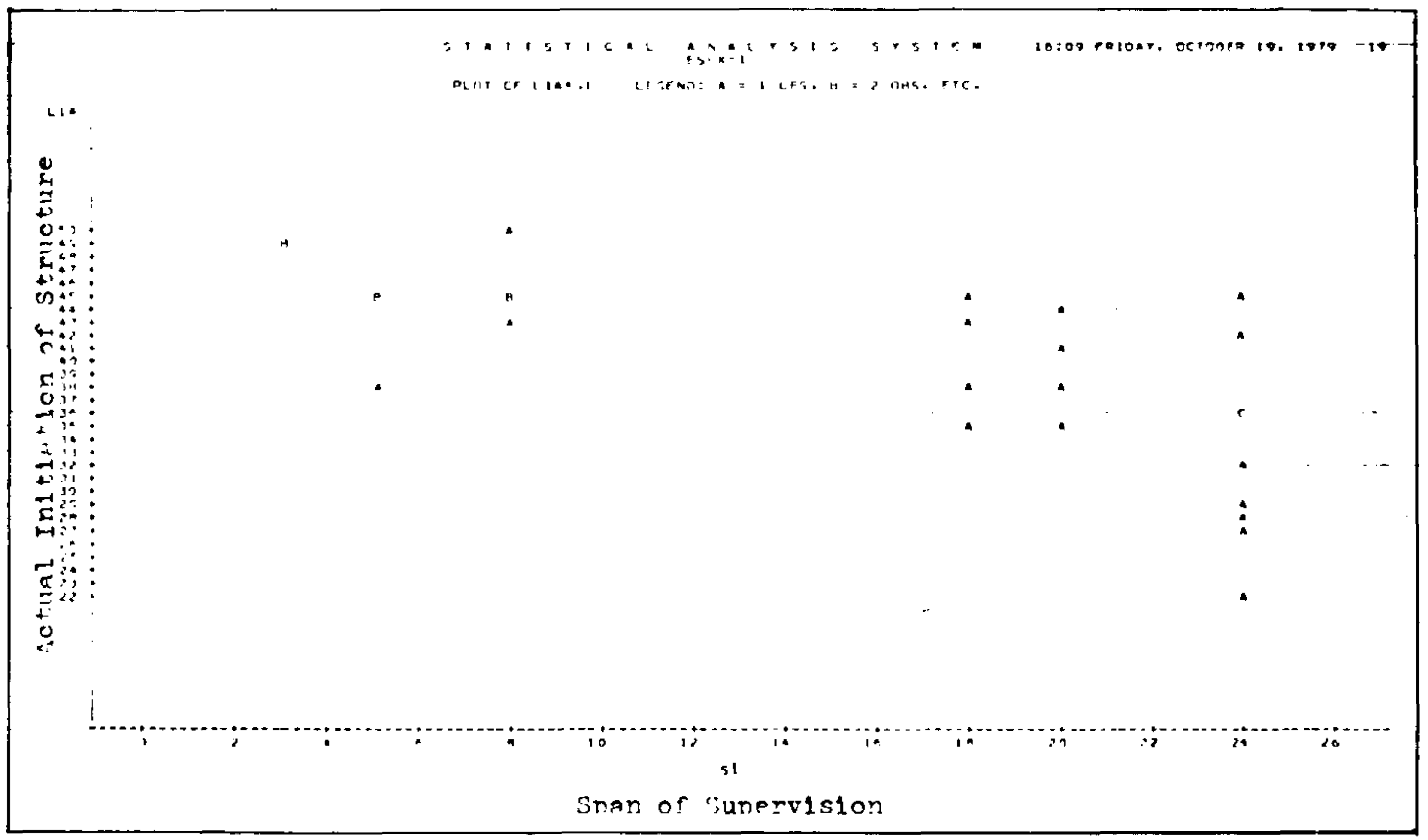


negative correlotion hetween the variables, combared to the one verifled in filgure $4-1$. The corresoonding fitted =pression line is oresented in Fizire $4-4$. Tolle 4 - c oresents the results of the refression analysis respectivel". The coefficient of deteminatior 1moroved to.4?, from.2I for non-classifled data, and was statistlcall" sianiflcent ot . c00l level. $1^{L}$ In the groun of remale emolorees, the two varighles of san ant ectual (bercelved 1ritiation of structure did not show o smiler sionlficant correletion. "1fure 4-5 reoresents a scatton तiforam for the tro variales in this grour. The corresnondinr fitted rearescion line is oresented in tifure $4-6$. Tomever. the anal. s1s of stotistios in Ta le L-" shoned the the low coeffletent of teterInation of .11 was still s+atis+1cali" sianificant.

Relationshio Petreen Actual (Percelved) Consideration and Span of Sudervision

$$
\text { The second simiflcant relationsh10, pmong tocel }
$$
relationshios, was found hetween actial (perceiver) consideration and span of supervision. Plfure li-? deolcts the disoersion of actual data points. The reader can visually verify a negative relationshin hetween the two variahles. A fitted rexressior 11ne, nresenter in Fioure $4-0$, helos the reader to visuglize a neatlve linear relationshin etween lationship than the one sugrested hy the coef lotent for non-classifled तata. 
Plonge $4=4$

Fltted ferression ine for Snat of iunervistou ind

Actual Inttation of Structure (Nale Emolo."ees)

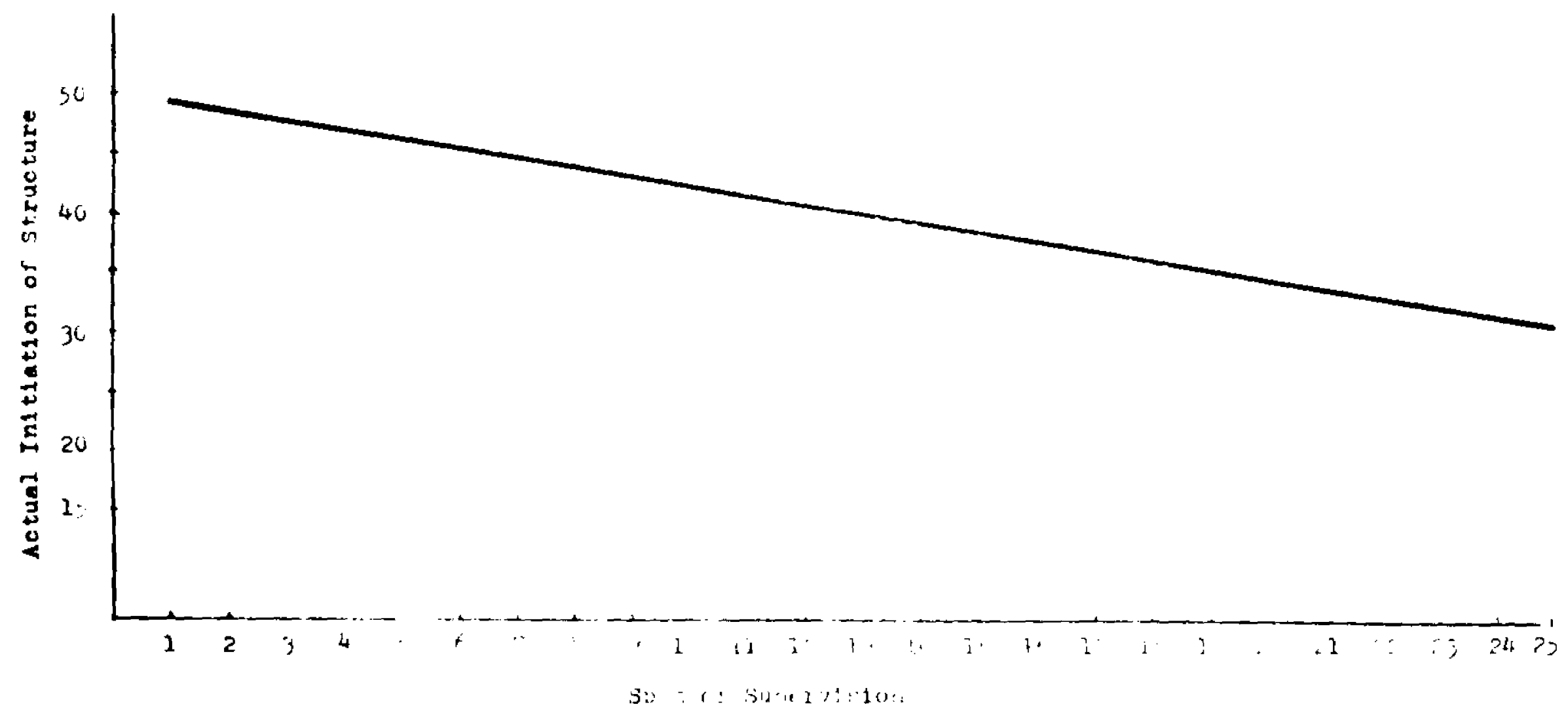


Tarle ltas

Results of the Rerression Retween actual Inttiation of ctructure and Soan of Sunervisior for Male tmolo:ees

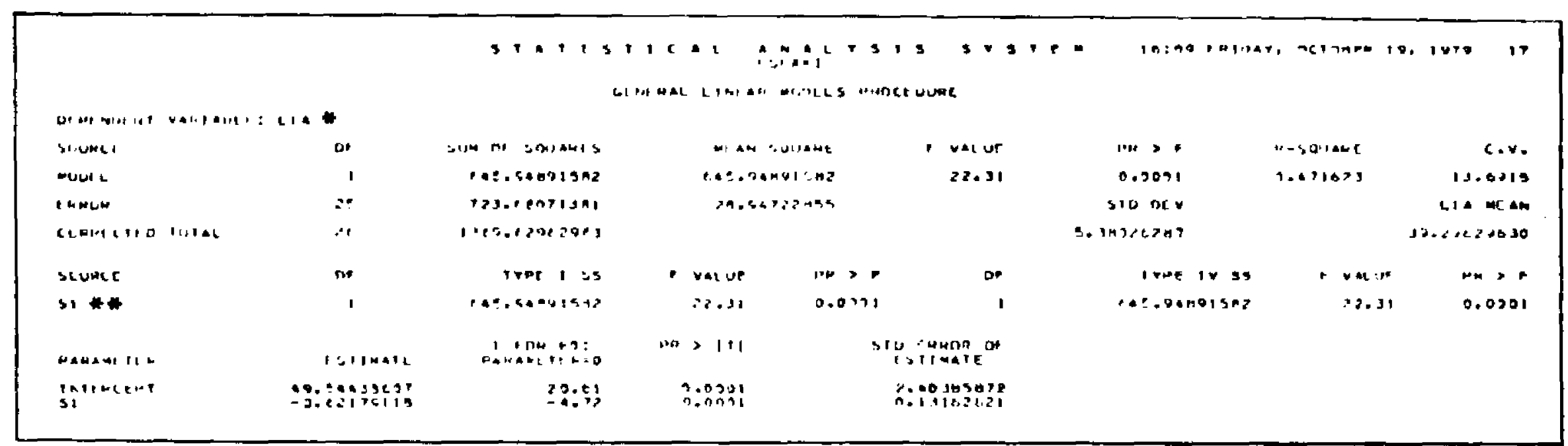

* LIA = Actidal Initiation of structire

* Sl = Span of Sudervision 


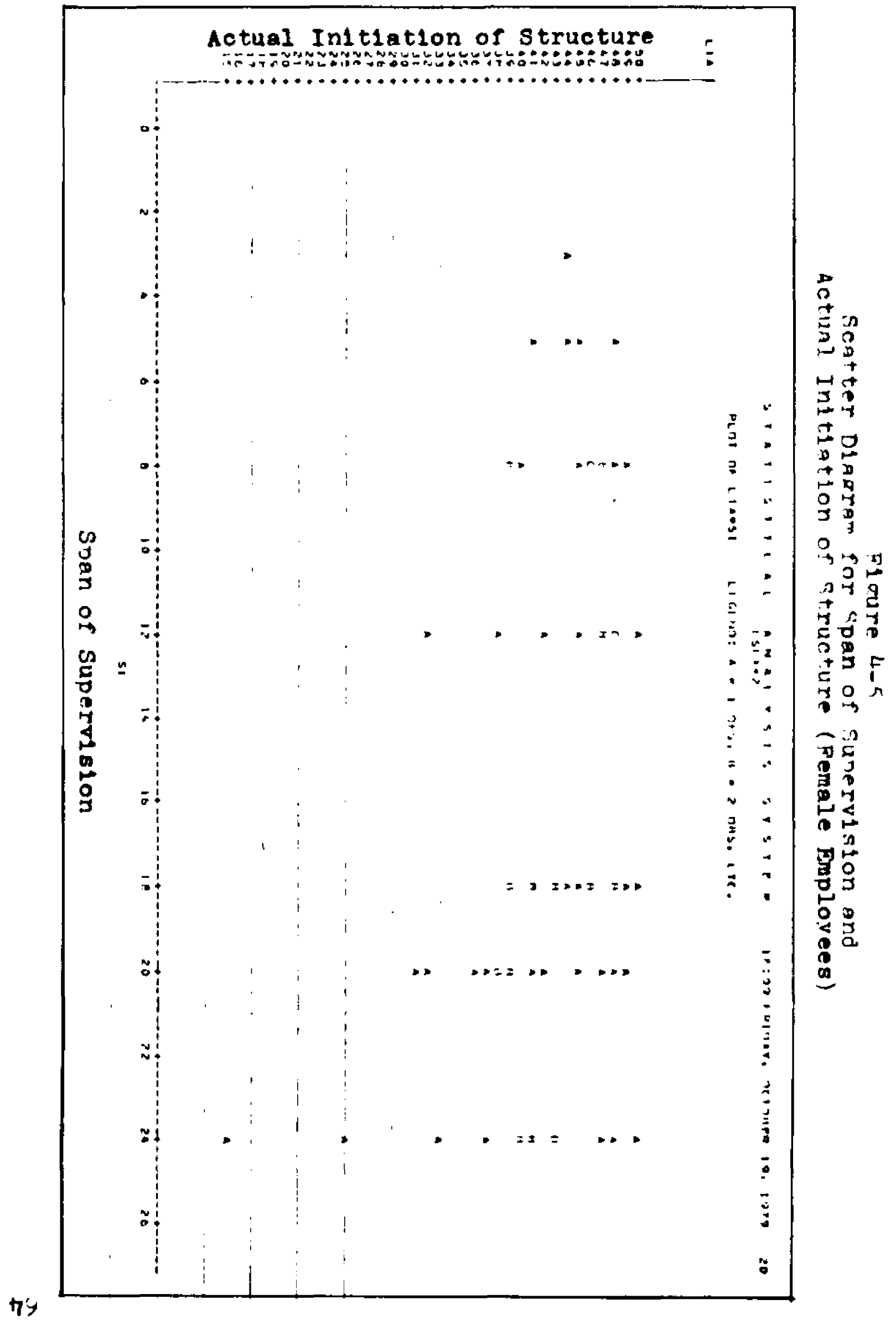


Flare 1-í

Fitted Repression I line for Span of Supervision and Actual InItiation of Structure (Female Employees)

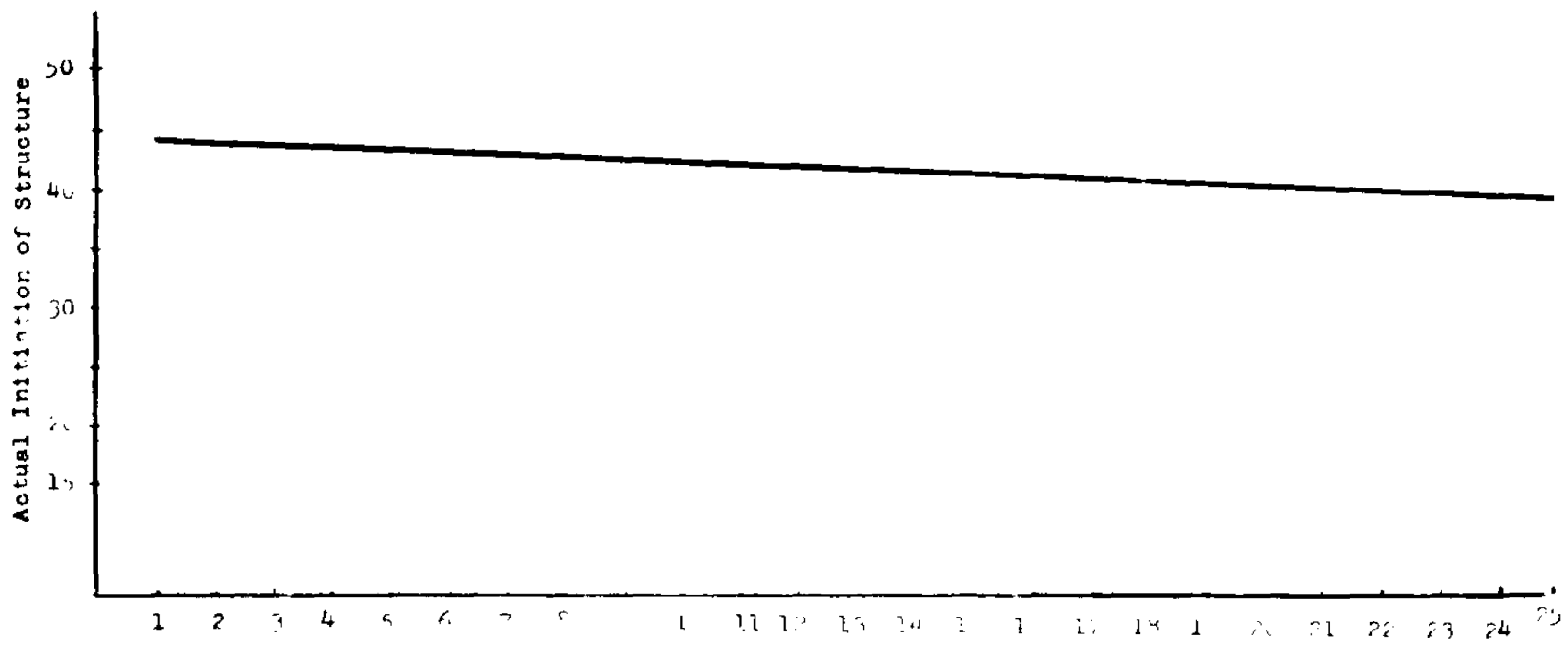

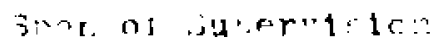

on 
Tarle $4-6$

Hesults of the Rearession vetween actual Initiation of Structure and snan of Sunervision for Female Emolorees

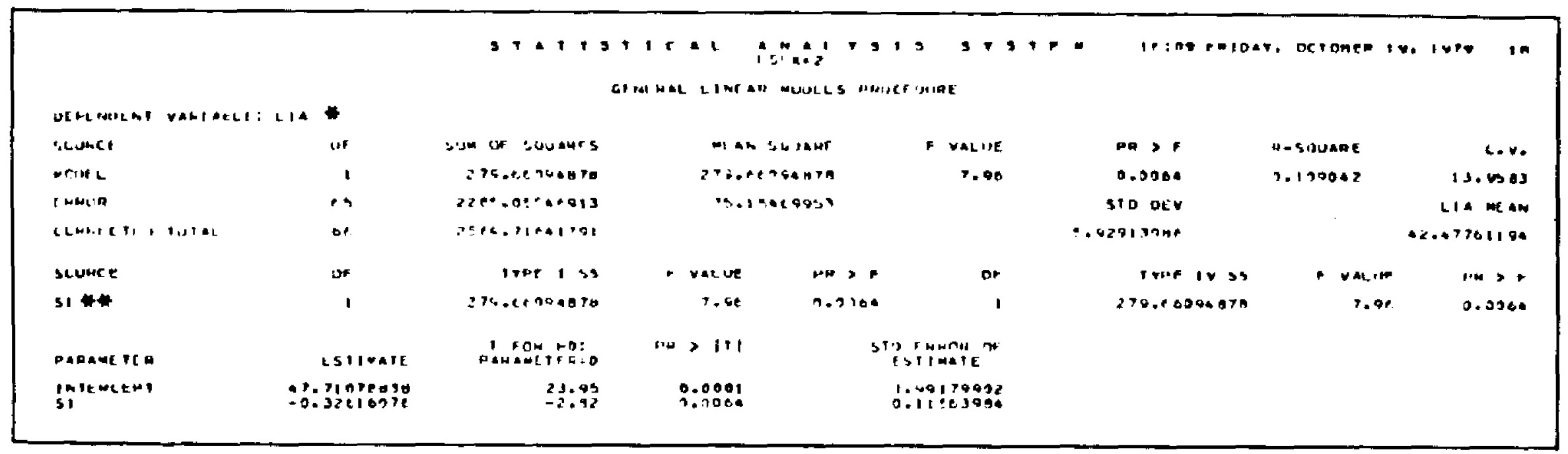

- LIA = Actual Initiation of Structure

* $s 1$ = Span of Subervision 


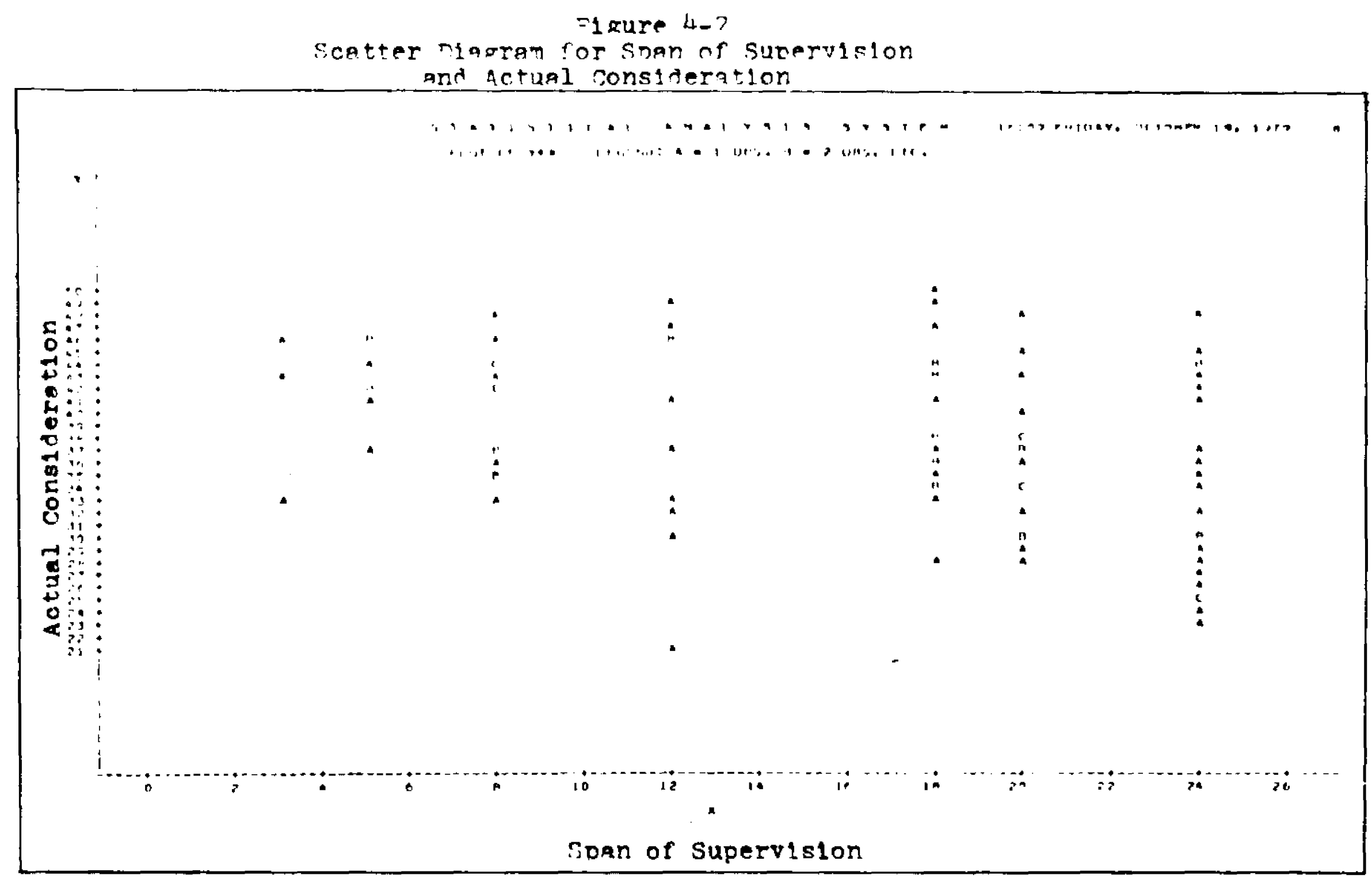




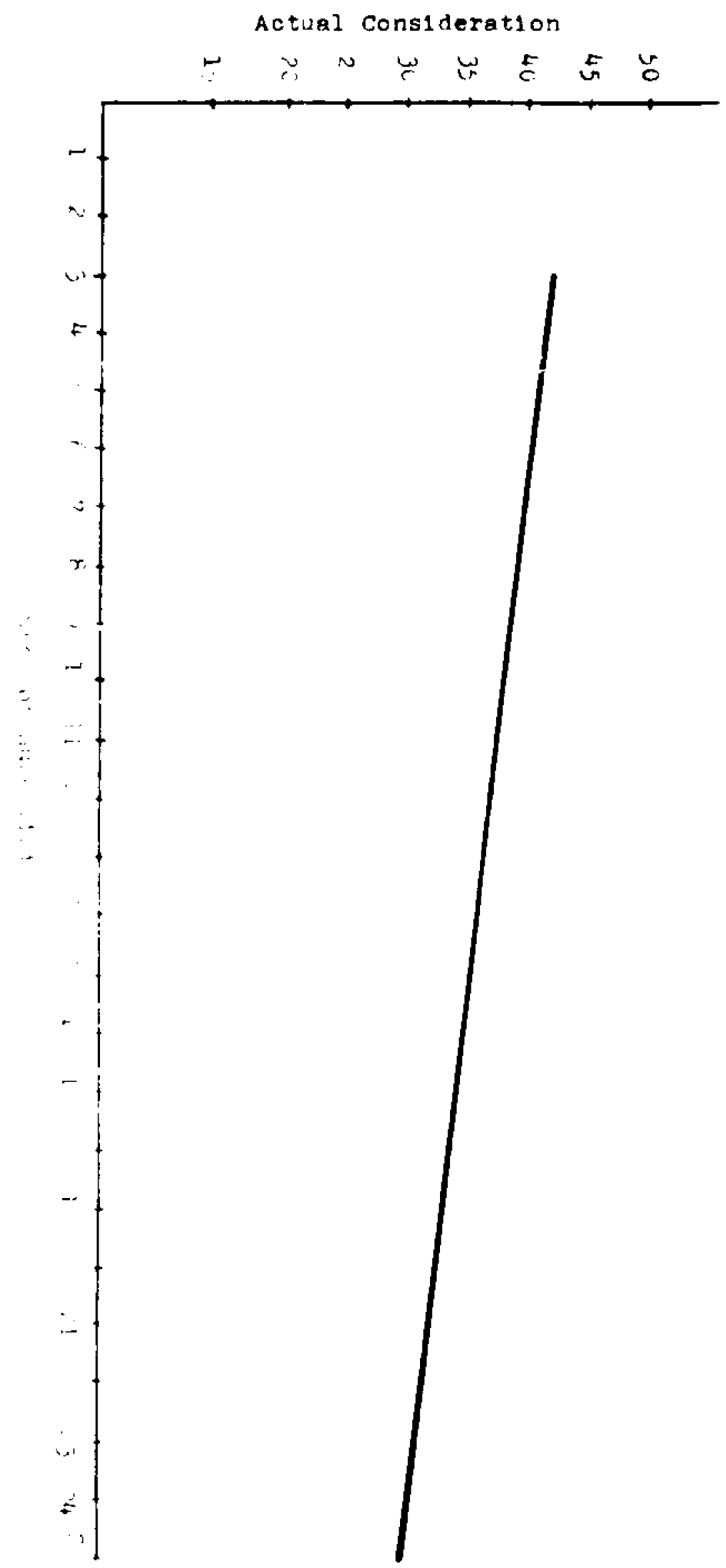

68

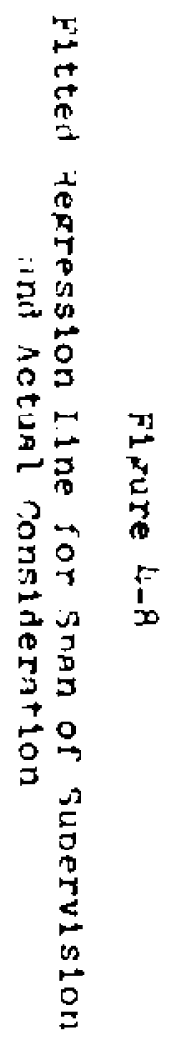




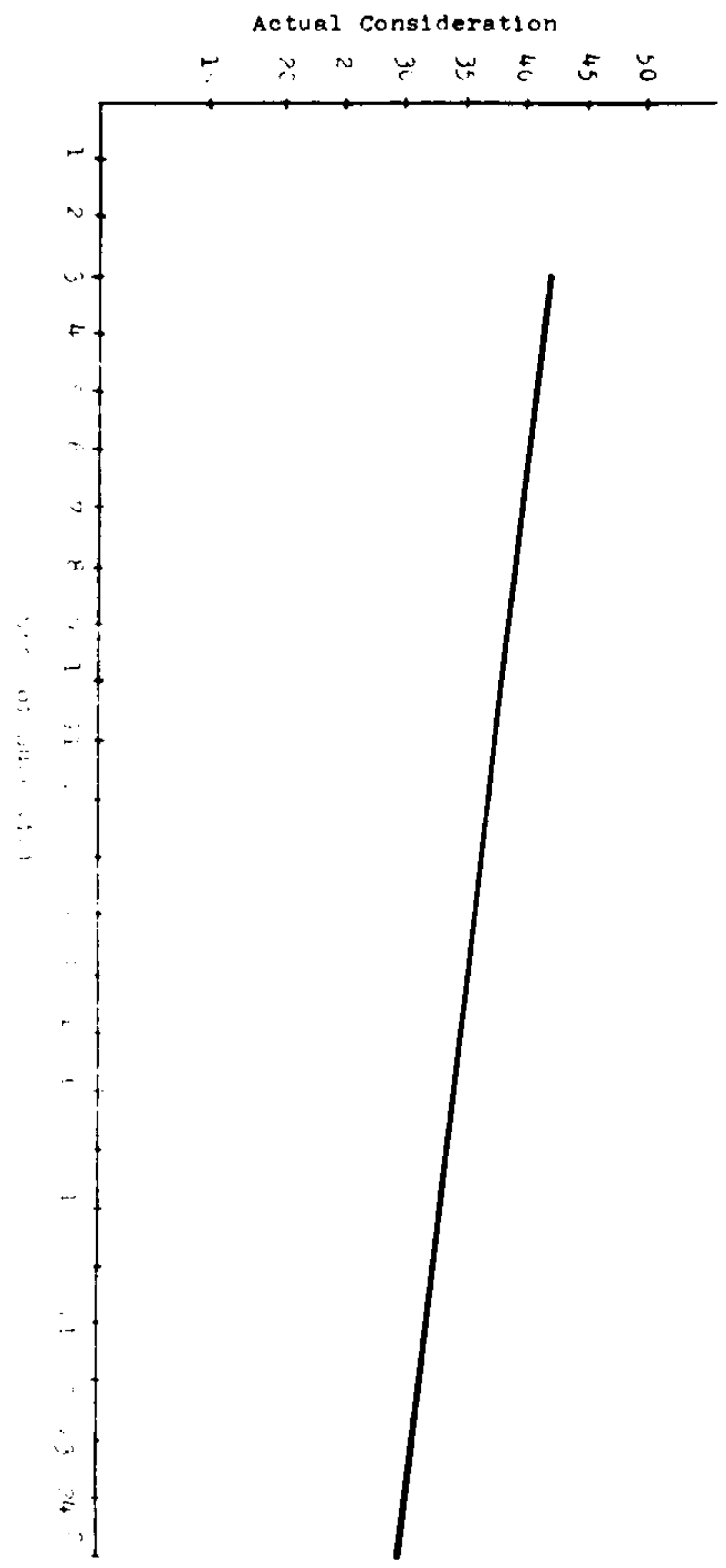

68

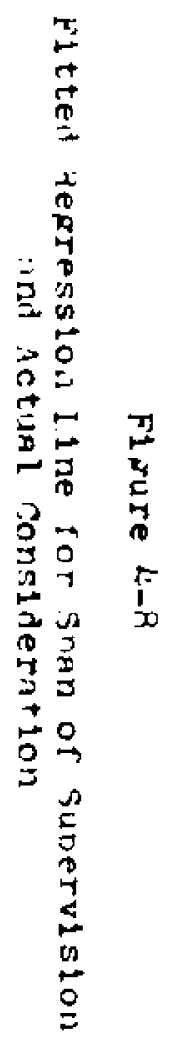


the two variables, and corresponds to the data graphed in F1pure 4-7. The fitted line suggests that as the value of span increased, moving from left to right on the horizontel axis, the expressed value of actual consideration decreased, the line moved downward. Tarle 4-? summarizes the statistics for the rearession analvsis. The coefflclent of determination of .14 , corresponding to the correlation coefriclent of -.37 reviewed earlier. has a high statistical signiflcance (significant at .0002 level). Estimates for the interception and the slode of the rearession line are provided for a mathematical expression of the relationship.

A clessiflcation of the data by emplovee sex proved to 1mprove the oredicted relationship between $8 \mathrm{pan}$ and actual consideration. The visual examination of the scatter dlagram for the nale portion of the sample, Flgure 4-9, leads to clesrer distinction of the negative correlation compared to the one for unclassified data. Figure $4-10$, fitted regression line, facilitates the verification of the regression line corresponding to the data doints on the diagrem in Figure 4-9. The signiflcant 1morovement of estimation, caused by classification of the data, is shown by improved $q^{2}=.36$, from .14 for unclassified data, significant at .0009 level (see Ta le 4-8). The values of the interception and tre slope of the regression line are also provided in Tahle 4-8. These values allow for the relatlonsh1p to he expressed in a 


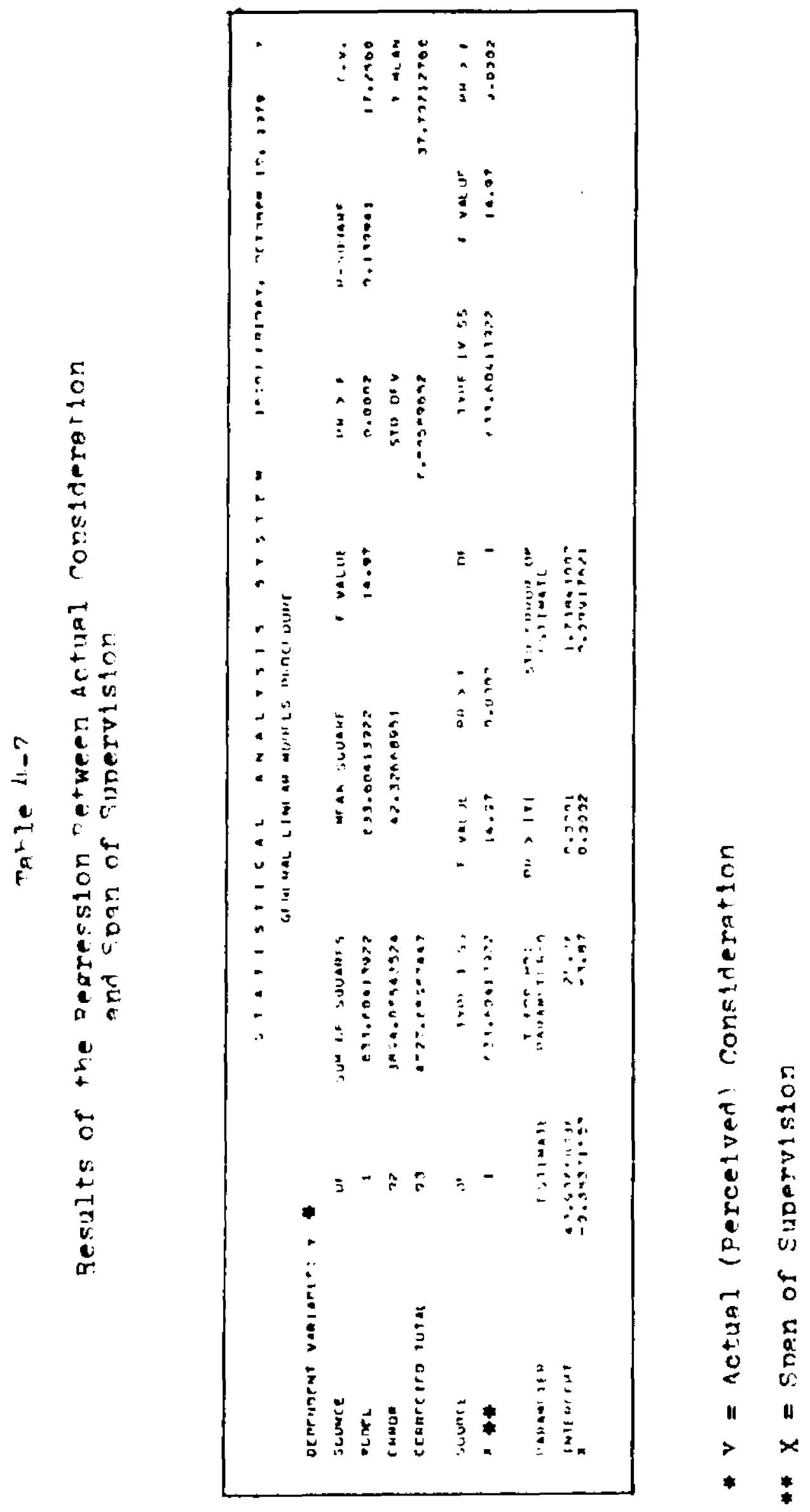




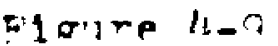

Scatter Diagram for roan of sinervicion

and Actual Consideration (MrIe Fmnlowees)

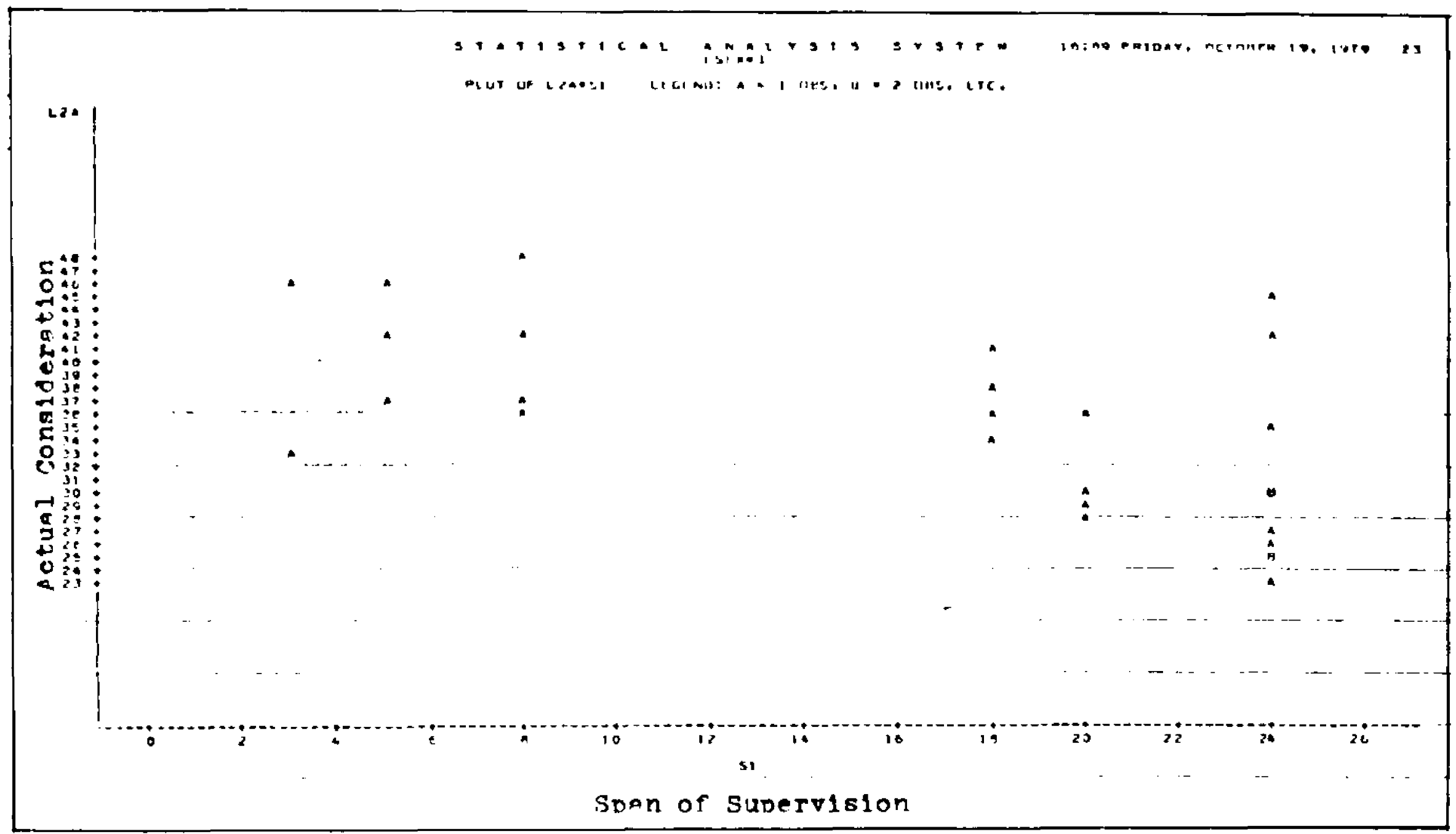


$\therefore$ fo:lre $t:-1$

Ftted iezression I lne for juan of jurervicion and Actial Consiceration ("ale Fmoloes)

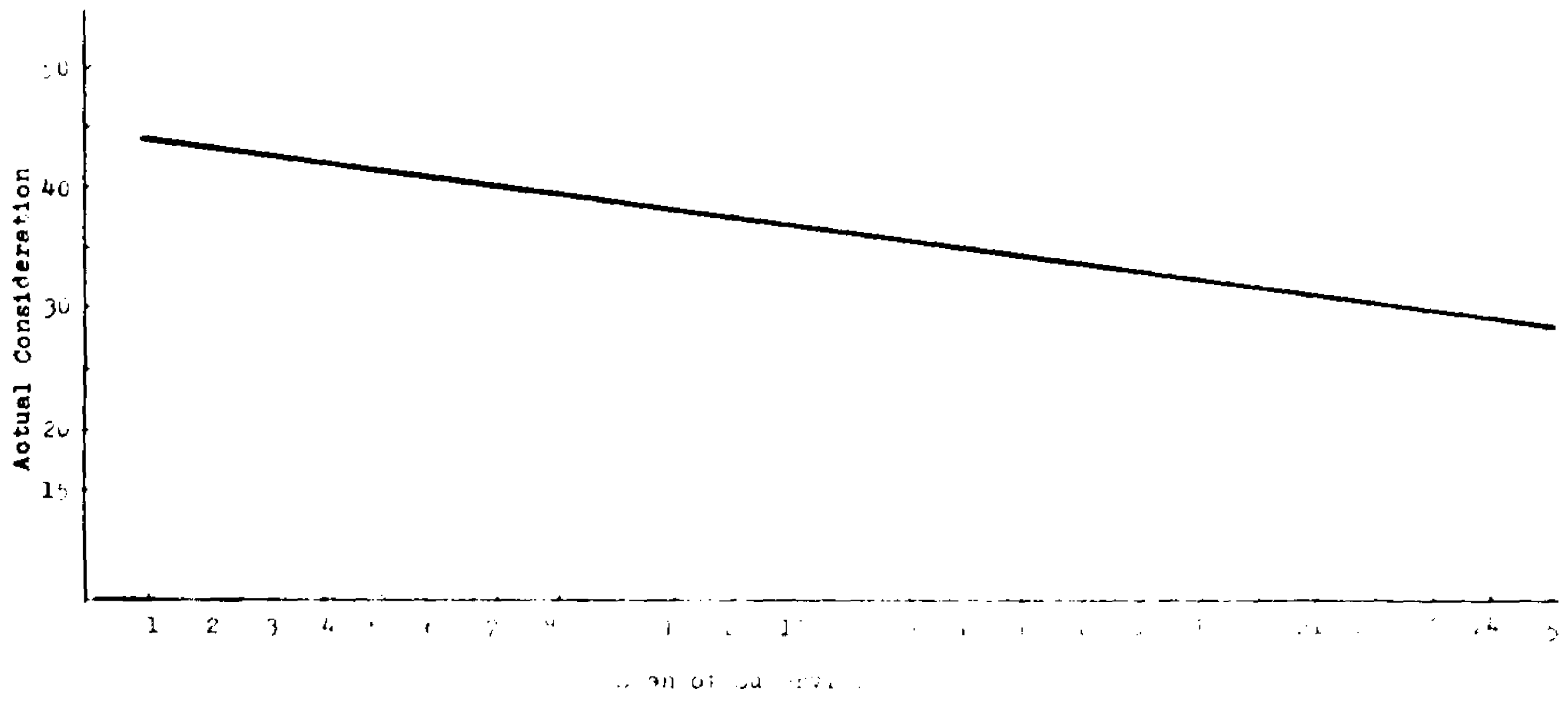

$\vec{N}$ 
tonle $4-9$

Results of the Rearession Fetween actual Consideration

and Soan of Subervision for Male Emolovees

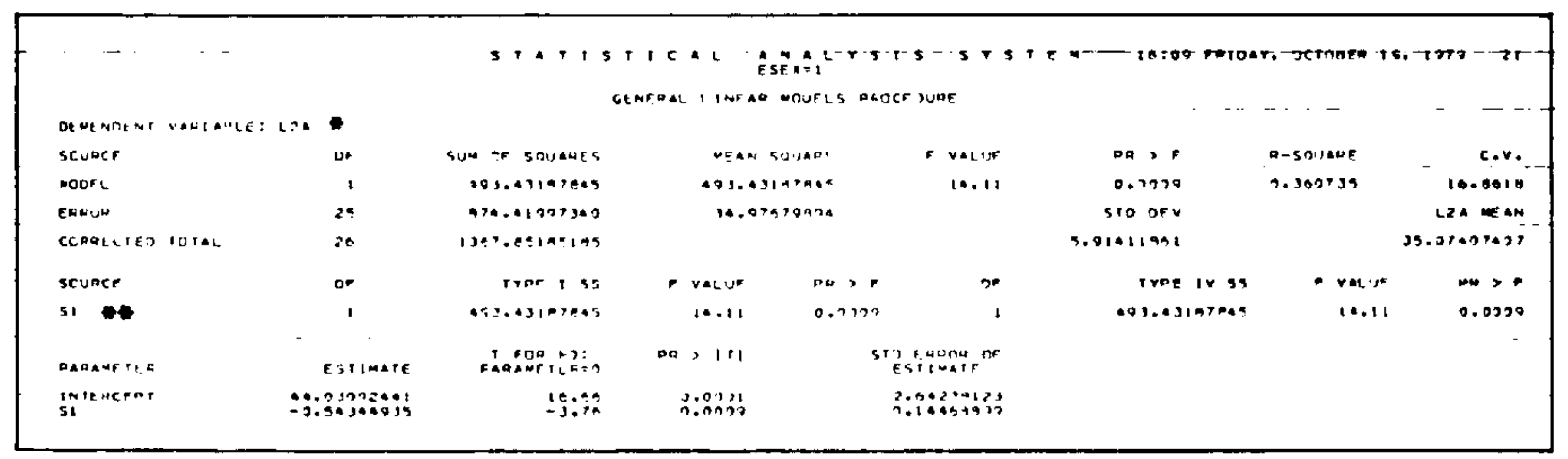

- IPA = Actual consiteration

* $\mathrm{gl}=$ Soan of Sudervision 
mathematical model. In the groun of female emplovees, tre association hetween span and actual (percelved) consideration was ver: low but st1ll statistically signiflcant. Figures 4-11 and 4-12 present the scatter diaram and the pitted regression lines, respectivel.. The $\mathrm{R}^{\text {? }}$ statistic for the rezression was of, reconflrming very low level of associotion between varlarles, hut was st111 statistically sienif1cant, at .03 level (see Tatle $4-9$ for the summary of rearession statisticsi.

From the preceding discussion of the correlation coefrlclents, the reader w1ll rementer that only two of the six focpl relationshios studied led to stetistically signiflcant relationshios. The anal'sis of the remaining four relationshios is the su-ject of the following section.

Non-signiflcant Relationsh1ps

As noted refore, four of the $\mathbf{s i x}$ focal relationstips atudied led to no statistically sienificant Indication of anv associetion. Although the presentation of correletion coefficients and the corresponding simificance levels 1s ugually sufficlent to conclude on non-existence of sipniflcant agociations. such conclusions could he reconfirmed by examining the corresoonding scatter diaprams. Flpures 4-1? to 4-16 represent the scatter diagrams for the four major non-gigniflcant relationships. The common denominator emono these diagrams is the $a^{\text {thence }}$ of a linear relationship, a 


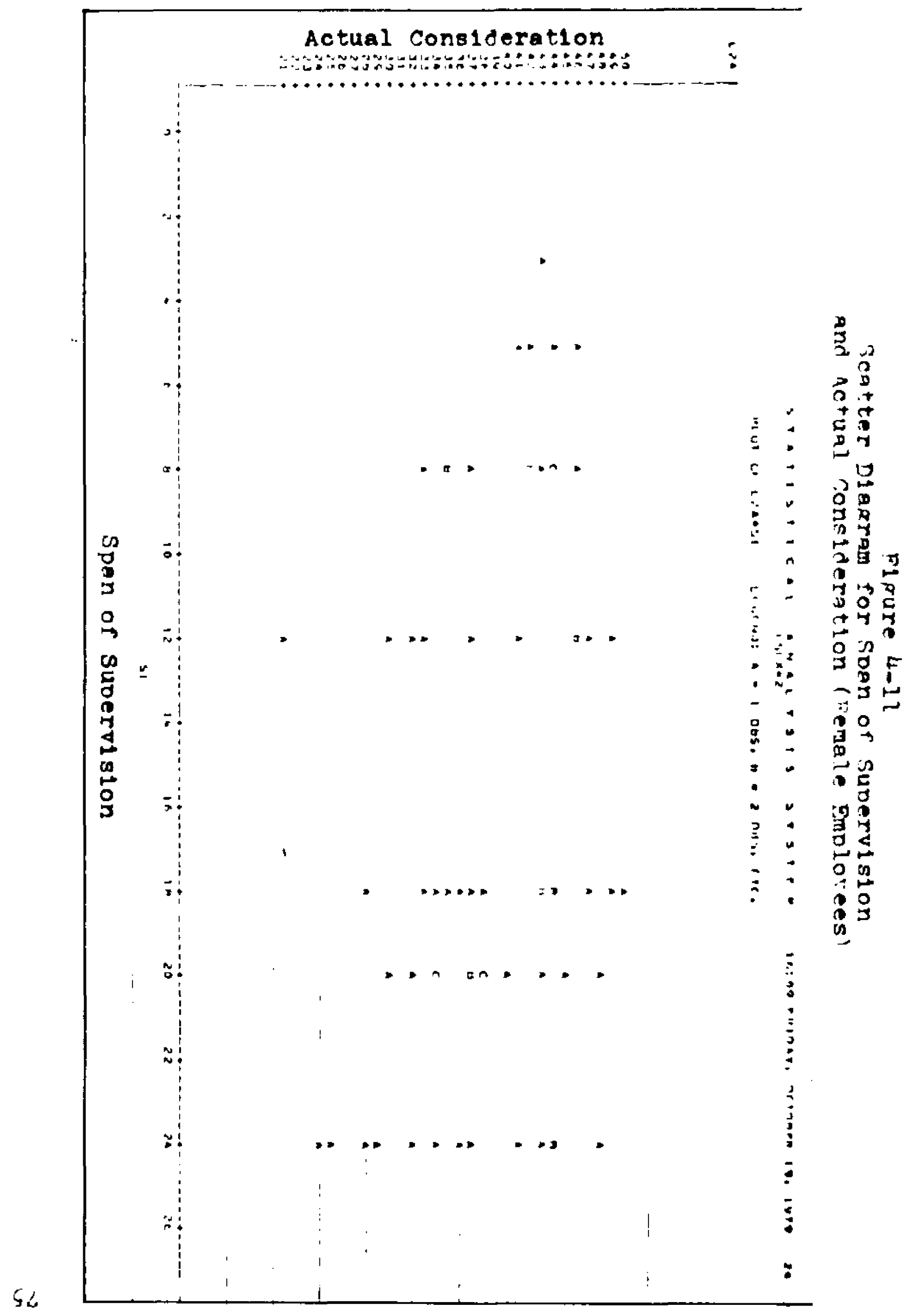




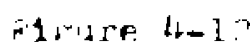

Fitted fewression I ine for; $n$ of Subervialon

and actual consineration (jetale eyilo.ees)

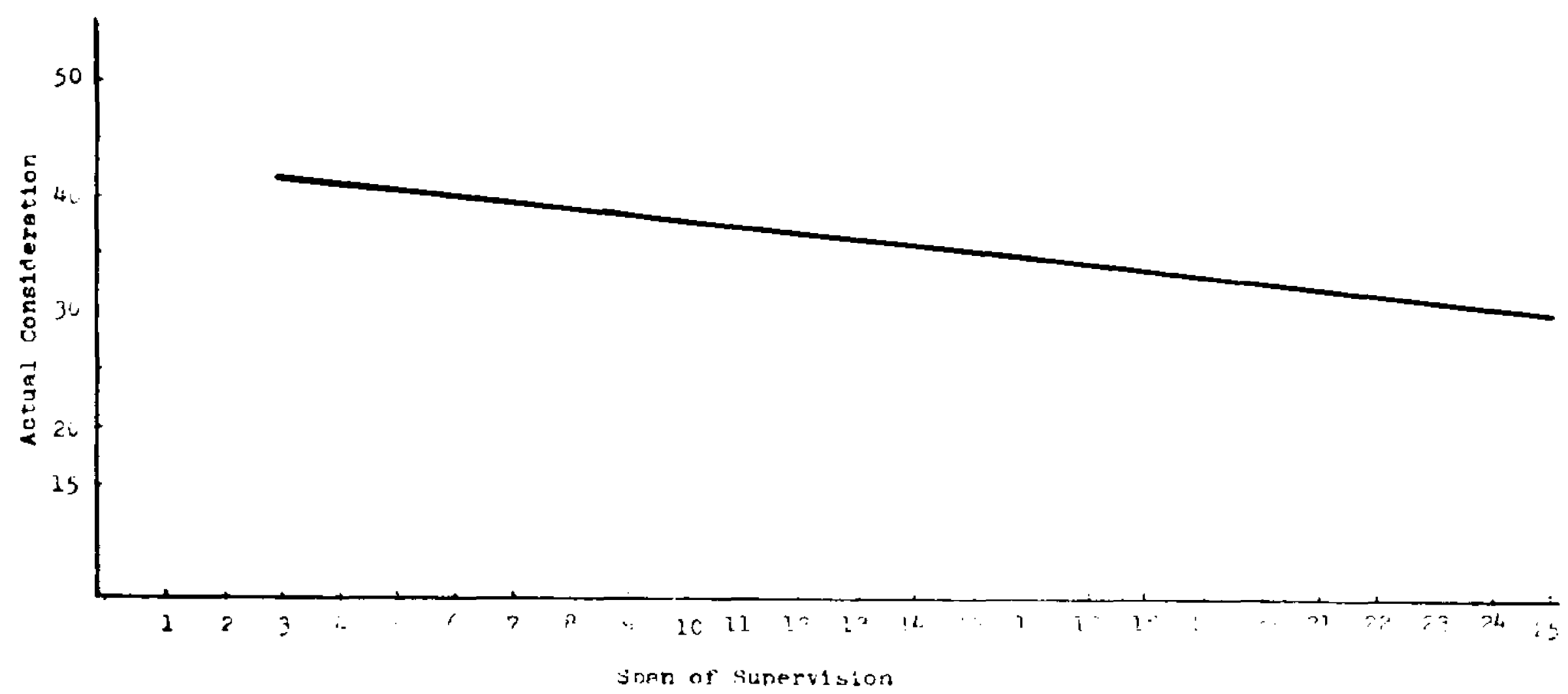




$$
m a-1 e 4-9
$$

Besults of the Jearession Between Actial Consiceration and Soan of Sunervision for Female Enolo"ees

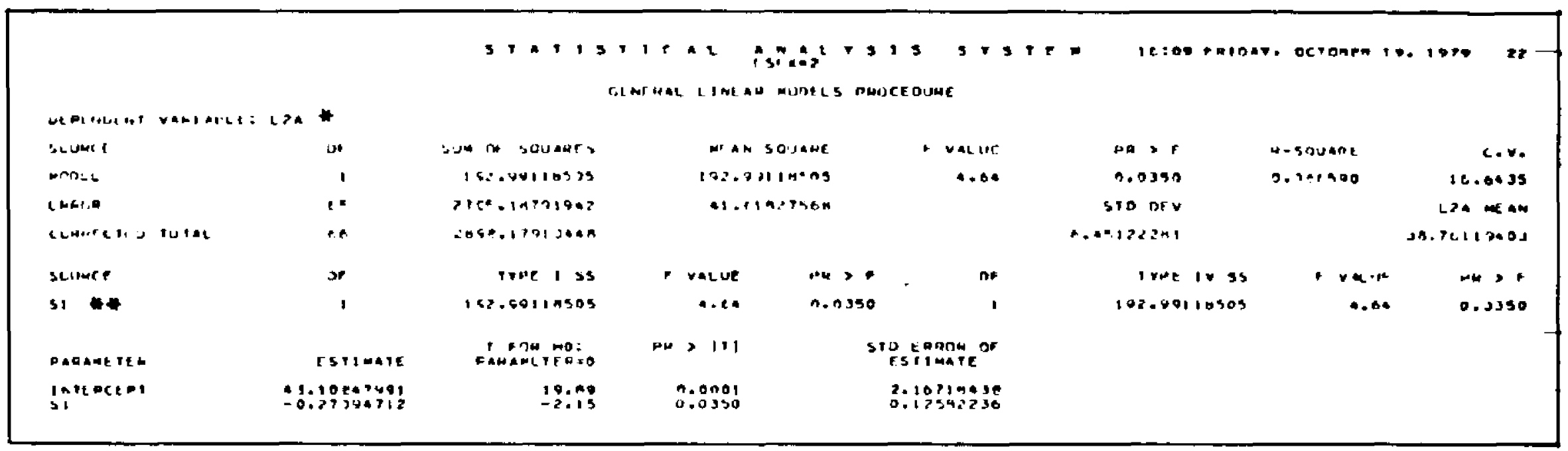

* Lla = Actual Consideration

* SI = Span of Subervision 
Fipure 4-13

Scatter Diagram for Actual Inltation of Structure and Fxpressed Int iation of structure

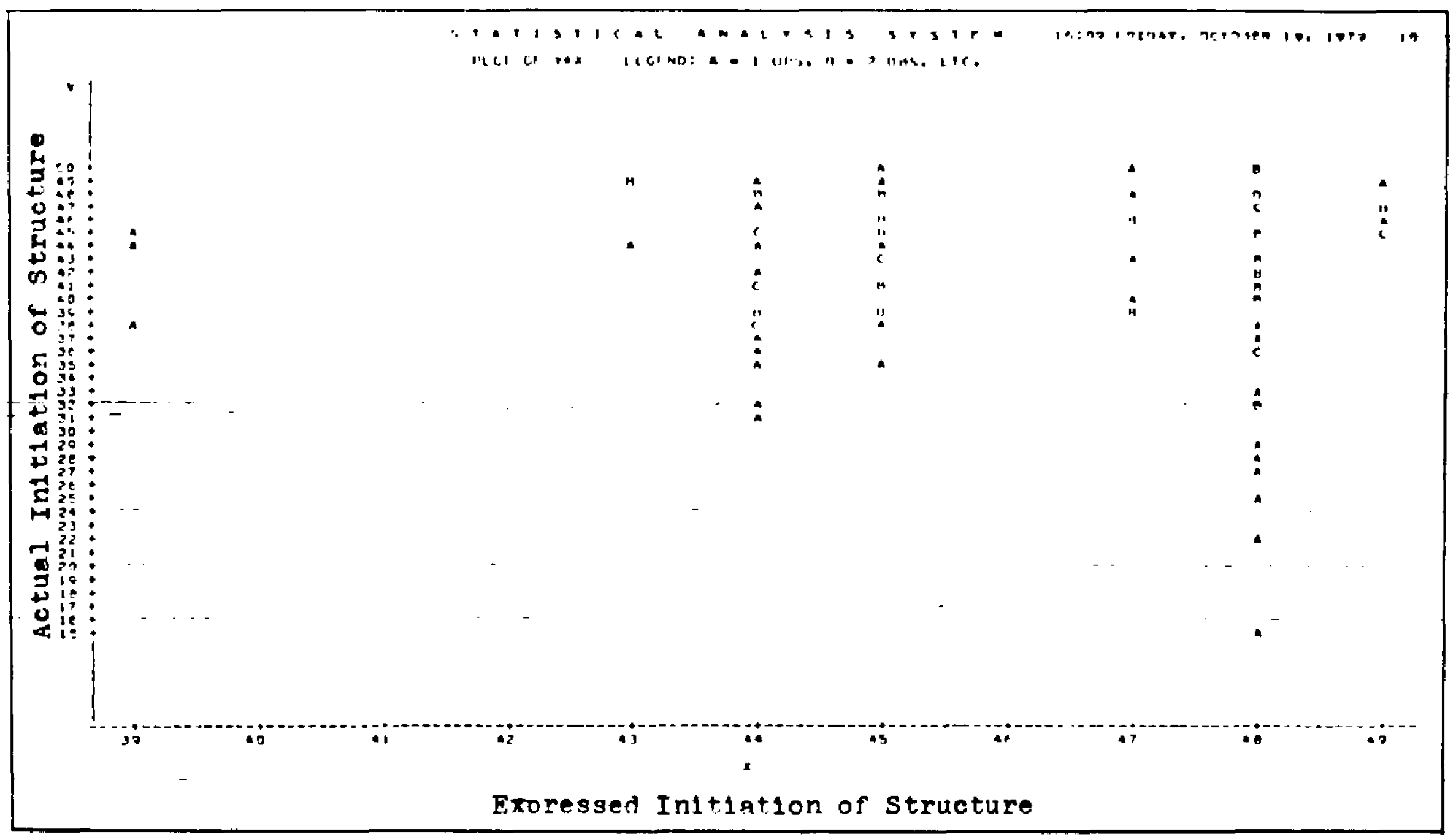


Fise 4-14

Scatter Diagrar for Actual Consideration and Exoressed Consideration

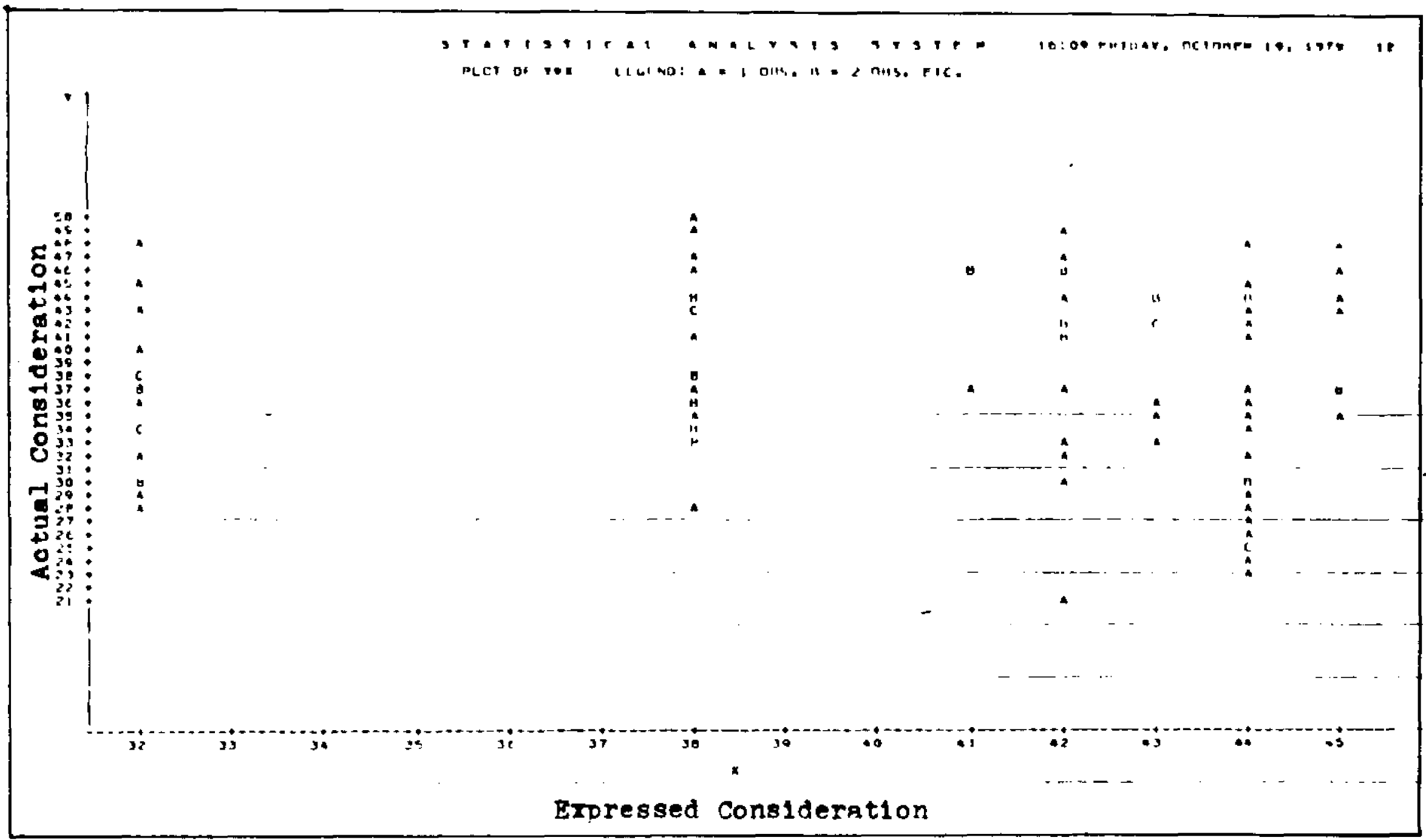




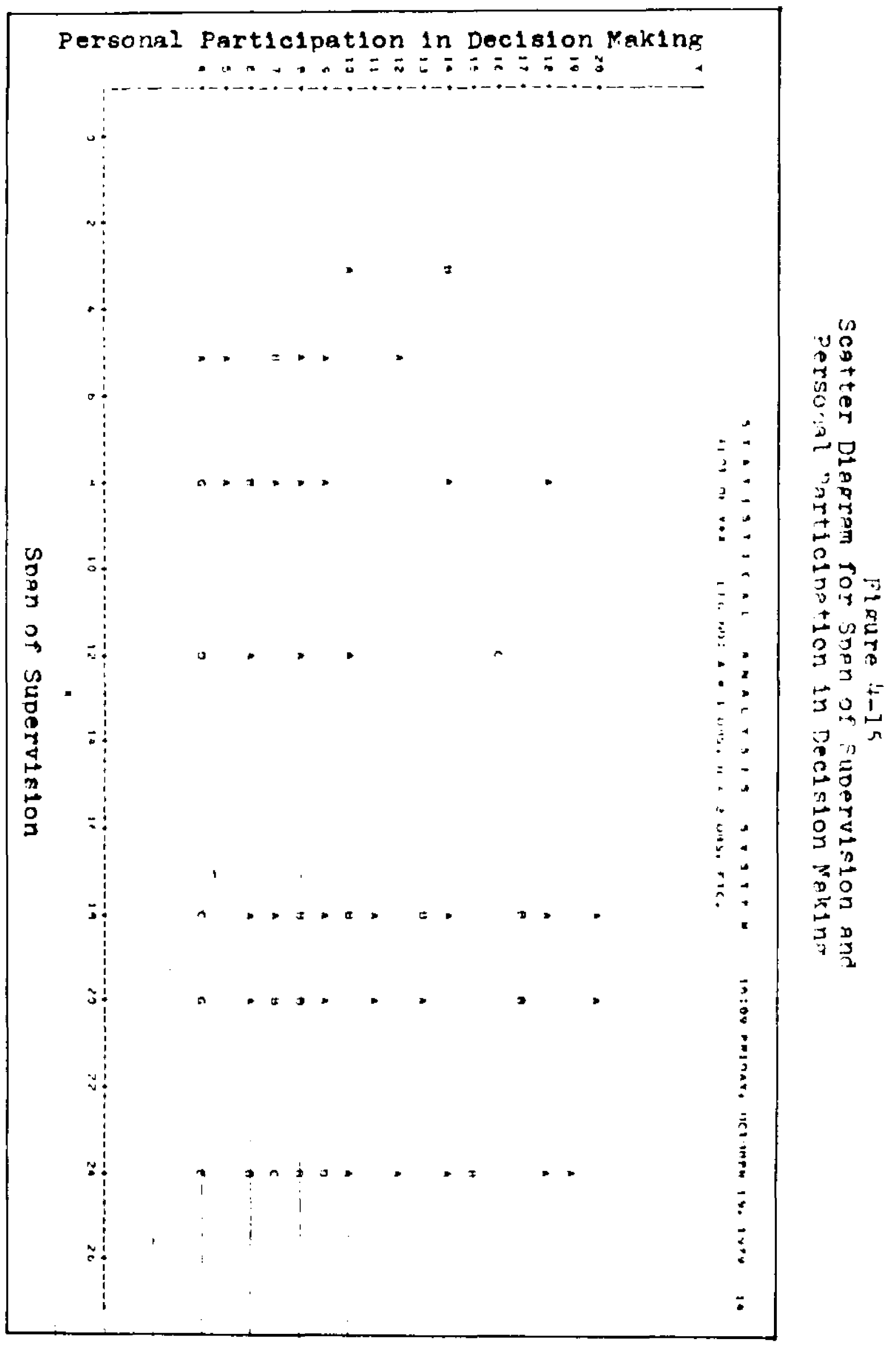




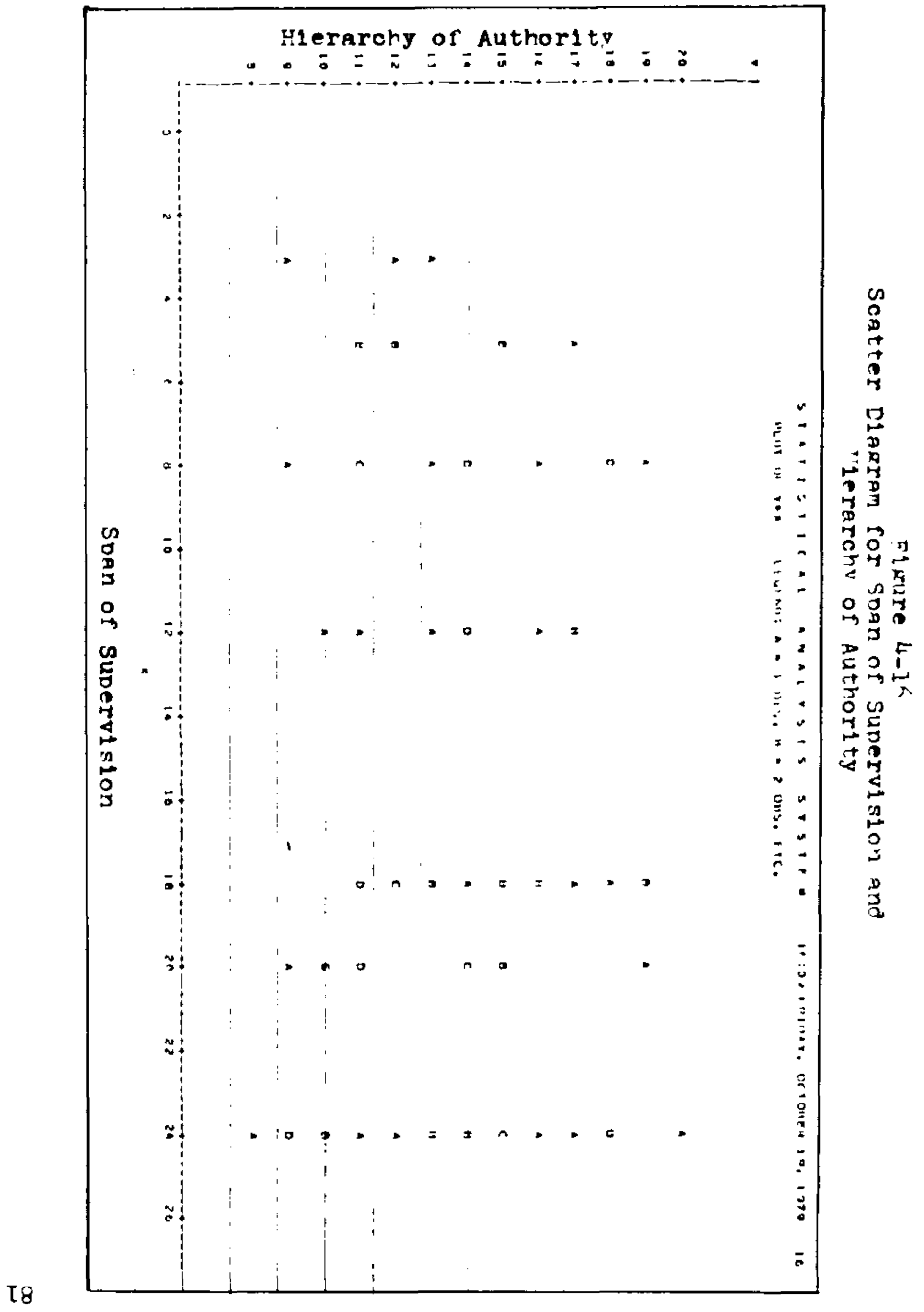


fact that could he verifled b" visual examination of diaerams. The lack of signiflcant correlation coefficients eliminates the need for the formation of regression models.

\section{Summar: of the Statistical Results}

The anslysis of the data of this study led to tre

rollowing findings:

1. There was a nexative relationsh1p retween the span and ectual (Derceived) initiation of structure. This relationshio wes found to be stronger among male emlo:ees and weaker among female workers.

2. A simlinr, hut sligrtl. weoker, negative relationshin existed hetween spar and actual (bercelved) consideration. The negative relationsh1p was found to he stronger for the sursamole of male emolorees and very weak among femele emplovees.

3. The retalnina four focal relationstios were not proven to re significant. In other words, ne1ther "actual" inltiation of structure nor "actual" consideration were related to their corresponding "expressed" varlables. No relationshlp was detected between the soan of supervision and any of the dimensions of centralization.

4. Some slentflcant Derioneral correlations existed between some major and classiflcation variables. These relationstios were discussed in more detatl in the relevant section of this analvsis. 
Summary of Results hy lypothesis

The findings of the study were used to test the six hypotheses atated in Chapter I. The following is the summarv of the results hy these hypotheses. The discussion on each hyothesis includes statements of "null" and "alternative" hypotheses followed by a conclusion of the testing procedure.

HYPOTHESIS I :

$I_{0}:$ There 1 s no relationship tetween "span of superv1slon" (S) and "personal particlpation" (Cl).

$A$ : There 15 some relationship retween $S$ and $\mathrm{Cl}$.

Conclision: The null hyothests of no relationship retween $S$ and $C l$ wos not rejected.

F: FOTHESIS II:

"०. There is no reletionstin etween "soen of sipervision" (S) and "hierarch" of author1tr" (C?).

A : There $1 \mathrm{~s}$ some relationshio hetween $S$ and $C$ ?

Conclusion: The null hypotresis of no relationship hetween $S$ and $C$ ? was not rejected.

F. PCTESIS III:

$F_{0}$ : There is no relationshio retween "spen of supervislon" (S) and "actual initiation of stricture" (I IA).

$A$ : There is a relationshid between $S$ and I $1 A$.

Conclusion: The null hypothesis of no relationship retween $S$ and IIA was relected with .0001 orchamility of rejectino a true null hynothesis. 


\section{HYPOTHESIS IV:}

$H_{0}$ : There is no relationshio between "span of supervision" (S) and "actual consideration" (I 2A).

$A$ : There is a relationshib etween $S$ and $L 2 A$. Conclusion: The null nvpothesis of no relationstip retween $S$ and I $P$ A was rejected with .000 ? probahilit: of rejecting a true null hypothesis.

IYPCTITESIS $\%$

Yo: There is no relationship between "actual initiation of structure" (IIA) and the leader's "expressed" rel lef a out initiation of structure (IIF).

A : There is a relationsh1p ietween LIA and LI3. Conclusion: The rull hrothesis of no relationsh1p was not rejected.

ITPOTESIS VI.

Fo: There is no relationshin between "actual consideration" (I PA) and the leater's "expressed" belief about consideration (L?F).

$A$ : There is a relationshio between $I 2 A$ and $L 2:$. Conclusion: The null h:dothesis of no relationsh1p between $L 2 A$ and $L 2$ ? was not rejected. 


\section{INTERPRETATION OF THE RESULTS, CONCLUSIONS, AND SUSGESTIONS FOR FUTURE RESEARCH}

The results of the research reported in Chapter IV are interpreted and 11 scussed in this chapter. The chapter begins witr a trief sumary of the study, and then the relationship retween span of supervision and various components of the directiveness of leadershio style are examined. Nert, a discussion on sunderentary relationshios discovered in the research is oresented. A "summary and conclusion" section follows, wherein some possirilities of practical applications of the findings are explored. The final part of the chadter is devoted to suggestions for further research.

\section{Summary of the study}

The primary purpose of this study was to examine the relationship hetween "span of supervision" and "directiveness of leadershlo stvle." The latter varlahle was measured along the four dimensions of inltiation of structure, consideration, participation in decision making, and hierarchy of author1ty. To messure the relationsh1ps, an "Employee Questionnalren was completed ry 94 restaurant emplovees of various work-group sizes. The manager of each work group also completed a questionnalre which provided information on his heliefs about wat comprised an mproprlate leadershlp style. 
Correlation and regresalon analysis were used to detect associations hetween the varlables under study. The findings of the study indlceted highly olgnificant correlations between the span and the rirat two dimenglons of leaderahip directiveness, 1.e., ectual initiation of structure and actual consideration. The remalning two dimensions were not Bignificantly correlated to spen. A more detalled presentation of the research findings is included in chmpter IV.

\section{Belationship petween Span of Supervision and the Directiveness of Leadership style}

The interoretations on the relationshios of span to the four dimensions of the directiveness of leadership style are made in this vart. The rirst two measures of leadership directiveness, 1.e., Initiation of structure and considerstion, are the most conventionallv used measures of leaderahip since the onto state studies. 1 The discusaion on the relationships of each variable to span includes an examination of the asociation between actual and expressed (hellef) measurements for that variable. The relationship hetween initiation of structure and consideration are then discusaed. The last two measures of leaderahip directiveneas, peraonal particlpation in decision making and hierarchy of authority, were two dimensions of a centralization acale developed by Questionnaire - Forw XII, Dp. B-II. 
Hage and Alken. ${ }^{2}$ The associations between span and these centralization variailes are investigated in the latter part or this eection.

Interpretation of the Relationship petween Span and Initiation of structure

The findings of the study detected a relatively strong negative correlation hetween span and actual initiation of atructure. 3 The correlation coefficlent of -.46 was the largest, in holute terms, among the coefficients corresponding to major relationships, and indicated thet wider apan was associated with less initiation of atructure. 4 The high level of statistical signiflcance of the coefficient $(P=.0001)$ showed that there was only a .0001 prohan 111 ty of discovering the association by chance.

In the interpretation of the negative correlation between span and actual initiation of structure, two 1 ssues deserve attention. First, as noted in the previois discission on methodology in Chmpter III, the relationship hetween span and Initiation of structure could be affected by the leader's peraonal inclinatione to practice a given leadership etrle. The reader 111 also rememter that the resenrch design pro-

\section{Hage and Aiken, "Reletionships of Centralization} to other Structurel Proderties", Dp. 78-79.

3 see Tahle 4-? for correlation coefficients for major assoclations.

LFor a derinition of variables, see the eppropriate section in Chapter I. 
vided for the elimination of the effect of this intervening varlable by measuring the leader's nexpressed" bellef about "an appropriate" leadersh1p stvle and by assessing the lmpact of this belief on his "actual" leadership behavior. A short reference to Tatle 4.2 reveals that this study found no significant correlation hetween "exoressed" inltiotion of structure and "actual" initiation of structure. The absence of such a contaminating effect of the intervening variable could be considered as positive phenomenon which reconflrms the accuracy and the significance of the detected correlation hetween apan and actual initiation of structure.

The second 1 ssue that deserves attention in interpreting the span/actual-initiation-or-atructure relationship concerns the measurement of actual initiation of structure. To measure this dimension of the "actual" behavior of the leader, the emplovees were asked to describe their "perception" of the leader's behavior. Since perception of actual behavior seldom perfectly matches the reality of these hehaviors, the interpretation of the findings should he made with caution. 5 Many personallty variables, as well as situational factors, affect one's perception. One such a ractor 18 sex. When used as basis for diriding the sample into two groups of male emplovees ond female employees, sex

5 Th1s ract was noted as a 1101 tation for the study in Chapter 1. 
proved to have significant lupact on the relationship between actual initiation of structure, as percelved by the emplovees, and apan of supervision. In the group of male employees, the correlation coefficlent for the assosiation between span and inltiation was -.69, suggesting that as size of span increased, the leader was percelved as initiating less structure. The obsolute value of the coefficients rose .23 points as a result of the classification (f rom -.46 to -.49 ), and the new coefflcient, for the group of male employees, was stat1atically significant at . COOl level. For the group of female employees, the association hetween span and actual (percelved) Inttiation of structure was less ( $r=-.33$ compared to $r=-.46$ for non-classifled data), hut st1ll stat1stically significant.

The discovery of negative correlation between spen of supervision and intiation of structure reconfirws the evidence provided by sowe earlier researchers and contradicts the work of some others. This rinding 18 consistent with the proposition made by House and Miner that supervisors wi th a short span tend to supervise more closelv. 6 Nevertheless, the researcher does not apree with these authors' advocacy of a broad span of control. He belleves that the

6Houge and Miner, Merging Management and Behavioral Theory: The Interaction Between Span of Control and Group S1ze", D. 455 . 
discovery of a negative correlation does not necessarliy support the notion that, given the opportunity, the supervisor as a power holder tends to exercise his/her authority over his/her suhordinates. ' In fact, the negative correlation could he cue to situational factors, an 1ssue that will be further discussed later in the chapter. The evidence provided in this research could he interpreted as contrary to that provided $" y$ remoh1u, who helleves the leader of a larger group tends to exert a greater degree of impersonal direction connected with flmness and Impersonality in the enforcement of rules and regulations - 1.e., a wider span is correlated to higher task orlentation. ${ }^{R}$ The conflicting conclusions could the result of the differences in wethodology and sitiational context.

Interpretation of the Pesults ?etween Soan of Supervision and Consideration

The analusis of the study presented in Chapter IV revealed a strong negative relationship hetween span and actual (percelved) consideration. 9 The correlation coefficient

${ }^{7}$ The regder is reminded of the jeginning discussion in Chapter I which proposed a trianaular relationshio tetween organizational structure, power, and leadership.

8Hemph1ll, "Relationship setween S1ze of the Span and the ehavior of 'Superior Leaders'", po. 11-12.

${ }^{9}$ For a definition of varianles refer to chapter 1. 
of -.37 Indicated that as the size of span 1noreased less consideration, in the leaders hehavior, was percelved hy the employees, whlle when the span narroved the supervisor was seen as more considerate. There was .0002 probat 111 ty that the detection of this relationship was due to chance. 10

As 1 t was the case for the span/initiation of structure association, the interpretation on the span/consideration relationship should be made only with conslieration of the effects of two intervening varlatles: supervisor's leadership beliefs and emplovee's perceptual limitations. The discussion on the limitations of the study in Chapter I led to the conclusion that the leader's "hellef" on what comprised the appropriate leadership rehavior could influence his "actual" behavior. To deal with this ":elief" effect, the research methodology was designed to allow for measurement and analysis of the effect. In the analysis of the research, Chapter IV, it was noted that no igniflcant relationship existed between the leader's expressed consideration (h1s bellef) and his actual hehavior (as percelved ry the followers). The ahsence of a significant "helief" effect reconfirms the significance as well as the accurecy of the estimated relationship vetween apan and actual consideration.

The second intervening varlahle which could interfere

10 Refer to Tarle 4-2 or Append1x I for correlation coefficients of assoolation hetween major variables. 
in the measurement of the span/consideration relationship was "perceptual" 11m1tations of the emplovee. Ind171duals" perceptions are commonly affected by ariety of factors. One such factor is sex. Th1s study found that the ser of employees had major impact on how they "percelved" the ectual behavior of the leader along the consideration dimension. To atudy the effect of emplovee sex on the relationship between actual (percelved) conslderation and span of supervision, the employee responses were divided into two groups of male and female responients. For the groud of male respondents, the coofficlent of correlation improved from -.3?, for nonclassified respondents, to -.40 , with a high level of statistlcal signiflcance. ${ }^{11}$ For the group of female respondents, the assoclation was considerat $1:$ lower, with a correlation coefficlent of -.24 .1 ?

The negat 1ve correlation hetween span and actual consideration suggests that in a group with a wider span, the leader $1 \mathrm{~s}$ percelved as less considerate of the reelings of those under him. ${ }^{23}$ This suggestion is in line with Hewphills proposition that the leader of larger groups tend to be

11 The coefficient of correletion for the male respondents was $\sqrt{.36}=-.60$. See Tatle $4-9$ for relevant statistics. tistics.

$$
{ }^{1}{ }^{r}=\sqrt{.06}=-.34 \text {. See Tanle } 4-9 \text { for relevant sta- }
$$

13 For more specific definition of consideration see: Stogd111, Manual for Leader nehavior Description Questionnalre - Form XII, p. 3 . 
less considerate of the individual member and tend to be more 1mpersonal, firm, and impartial in enforcement of rules and regulations. 14

Interpretation of the Relationsh1p "etween In1tiation of Structure and Consideratior.

An 1mportant finding of this study was that the two leadershio variahles of initiption of structure and consideration were hiehly correlated, and this correlation was detected in hoth expressed (helief) and actual (Dercelved) measurements of the two varialies. A Dositive correlation netween the varlatles ex1sted for hoth "expressed" measurements ( $r=.69)$ and "actual" ( $r=.68)$, and corresponding coefflclents were statistically significant at .cori level. Such a positive correlation proposes that, when elther expressed or actual inttlation of structure kas hlgh, the conslderation also measured high along the respective messurement. S1milarly, a low initiation of structure was asociated with low consideration.

Two explanations could he offered to justify the finding, of such nositive relationshins. The first explanation seeks a methodologlcal answer while the second one provides a situational reason for their existence. To explain the findings in methodological terms, the reader $1 \mathrm{~s}$ reminded that the varianles of initiation of structure and consideration were measured along two surscales of a questionnalre 
used in The ohlo state Studies. The hikh interdependence of the two sungcales, renregented hv high correlation oetween the two measured voriables, could he interpreted as weakness of the questionnaire design. Wowever, this interpretation 18 not velid since the questionnalre has meen surject to frequent testing and has oroved to he highly reliahle and va11d. 15 Furthemore, the mere oroximitv of the correlation coefflclents for eroressed measurements $(r=.69)$ and actual measurements $(r=, \angle \theta)$ of 1 intiation of structure and consideretion, resoectivelv, Indicater not onl" the realitv of the relationship hid also the accurac: of their measurement. 16 An alternet1re explanation for the dositive relationshin retween initiation of stricture and consideration pronoses the callse of the association to he in the particular situational context which exists in the restaurant. Restaurant monapers have to deal the frequent oromlem of low skilied, uneducated, and apathet1c workers. One specialist sees labor os a major protlem for the management of food service operations. 17 Management reacts to the lotor ororlet

15 For information on the relianility ond validity of this questionnalre see 3 togdill. Manual for Leader aehavior Description Questionnalre - Form XII, pu. B-II.

16 If the relationghios were due to the faulty scale construction, as the first solution oroposes, the results would have heen distorted, and most probahlv led to different $r^{*}$. Hish levels of statistical signiflcance of $r^{*} s$ also indicate the accuracy of thelr astimates.

17 Zaccare111, "Inspirinp Good Management", p. 86. 
hy emphasizing coordination and issulng directions. Strict coordination of activities 18 verv critical for the efficient management of restaurants and prorarlv even sought by ewployees:

Without active intervention hy management... alwavs... peodle (emolovees) would he passive .... They must, therefore, he bersuaded, rewarded, 'ountshed', and controlled. Their activities must he directed... and this $1 \mathrm{a}$ mankger's task. IR

If close supervision and coordination of employees activities are so indortant for "effective" wanerement of a restaurant, then a whenevolent autocrat" would he hoth effective and highlv regarded ty emplovees. 19 However, coordination and close subervision hecome extremelv difflcult as the soan of supervision increases. Th1s difflculty has reen witnessed by other researchers. In his famous study in the restaurant industr., Whyte noted that as the size of the organ1zation increased, there was increasing difficulty in coordingting activities. ?

The line of facts presented a hove can heln to explain the positive relationshid hetween initiation of structure and consideration. That $1 \mathrm{~s}$, when the managerent was

$$
\begin{aligned}
& { }^{18} \text { Zacarel11, on. c1t., p. } 86 . \\
& 19 \text { The term "renevolent autocrecv" descrites a higrly }
\end{aligned}
$$
directive leadership stvie (high inltiotion of structure) comined with concern for enplovees (consideration). For the orleinal use of the term see: Hicks. The Management of organizations, Dp. $452-453$. 2? $302-310$ Whyte, "social structure of the Restaurant". pp. 
"effective", a henevolent autocrat with a small span of subervision, hoth initiation of structure and consideration were measured high. on the contrary, when management performed poorlv, due to either a large soan or inappropriate leadership style, low initiation of structure (11ttle direction) accompanied low consideration (11ttle concern for employees). The discission on the "effectiveness" of restaurant management 1 s revond the scode of this study and the presented discussion on causations is only used to provide an alternative explanation for the positive relationshid hetween the verianles under consideration.

Summary of the Relationships of Soan to Inltiation of structure and consideration

$$
\text { In hrief, the analysis of the date gathered rrom }
$$
the enployees of 9 fast rood restaurants led to the conclusion that in a laraer group (wider span) the behavior of the leader was percelved as less structure inltiating and less considerate of emplovees feelings. Stronfer negative relationshios were found in the analvis of data from male emplovees, whlle in the group of remale emoloyees the negative correlations were lower hut still signiflcant. The high levels of positive correlation inetween inltiation of structure and consideration could he explained in terms of situational conterts in the restaurant environment. In other words, the workers' dependencv on managers' direction and coordination prescrited a "renevolent autocratic" leadershio 
otyle; therefore, this situation caused an effective manager to score high in hoth initiation of structure and consideration, while a poor supervisor scored low in the two variahles. The hove explanation 18 based on two premises. The first assumbtion 18 that as span increased the effectiveness of leadershio decreased. 21 The second assumption is a derivative of the first one and states that there should have meen a point after which the marginal ut1lity of increasing the of soen sharoly declined; $1 . e .$, there was a limit to how large restaurant could e. The latter assumption 1mplles that there exlsted on "optlmum" span, or range of span, for fast food service operations. The notion of the existence of an "optimin span", or work group size, in the restaurant is in line with the conclusion derived hy Woodward and Hickson, et al., that in some industries successful oranizations did utllize soan close to the median of their production grous type. 2? Visual examinations of Figure $4-1$ ant lb-3 reveal that actual int+1ation of atricture hegan a shars dron he and a span of 18 to ?0. A similar trend can be distingulshed in

21

Th1s assumotion is hased on two oropositions. The rirst one was made ru whyte, stating that, ag the size of the work groun 1 noreases, coordingtion hecomes diffinult. The second Droposition :y Zacomrelil stated that a hioh level of coordination was necessary for affective manarement of food service operations. For more elaroration on prodoaltions refer to the latter part of the preoeding section. 22

Woodward, Industrial Organizations: Theory and Practlce; H1 ckson, pugh, ond Phesev, "oderations, rechnolory, and Organization Structure: An Emolrical Reaonralsal", Dp. 45-54. 
Figure 4-7 and 4-9 where actual consideration sharply declines heyond the span of 18 to 20 . The determination of an optimus: span was not the intention of this study and the ahove mentioned analysis was merely presented to further explore the nature of the relationsh1p hetween the variables under consideration.

In adiltion to initiation of structure and consideration, two other factors were used to represent the directiveness of leadership style. The following discussion examines the relationship hetween the soon and these two variables which were assoclated to centralizatior.

Interpretation of the Relationshid Fetween Span and central1zation Varlaties

The findings of this study ind icated no significant relationship hetween span of supervision and el ther measurements of centralization. However, personal participation in decision makine, the first measure of centralization, is one of the factors according to Litterer which are influenced by spen of supervision. 3 Nevertheless, the findings of prerious researchers do not provide a consistent answer to the nature of the relationship. Yealv studied the span of control in 574 organizetions and concluded that executives w1th larger spans tended to use more porticloative leadershio atvie. 24

23 I t terer, The Anglysis of organizations, p. r.59.

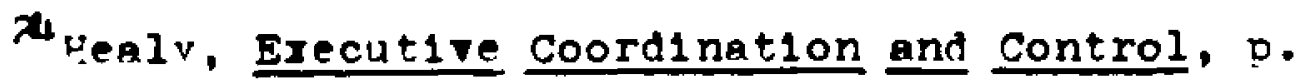


Contrary to Healv's conclusion, Feller and vulk found that the sharing of decisions with suhordinates was greatest when the leader had a narrow span of control. 25 conclusions of a research by Pennings were more in agreewent with Heller and Yulk's findines but the results were hardly statistically algnificant. 26 The inconsistency of the rindings of previous research and the ahsence of a sioniflcant relationship in the findings of the Dresent research and that of Pennings raise serious questions on I1tterer's proposition thet soan and particloation are associated.

The second measure of centralization used in this study was hierarchy of authoritv. House and M1ner suggest thot when soan is narrow the subervisor tends to delegate less authority.? This common conviction was not supported iy the findings of thls research. The findings of earlier research on the relationshio are also inconsistent. ${ }^{2 R}$ The inconsistency of these findings and the lack of a signiflcant relationshlo prodosed $y$ the oresent research cast dou ts on the existence of a relationshio hetween size of span and deleartion of authorltv to suhordinates.

25 Heller and vulk, "Perticlnation, Managerlal Decision Making, and S1tuational Varlables", pD. 227-241.

26 pennings, "Measure of Organizational structure: A Methodologlcal Note", p. 693.

27 House and Miner, op. c1t., p. 455.

28 For examples of conflicting propositions see: Iltterer, The Analysis of Oraenizations, op. Do. 559-573 and

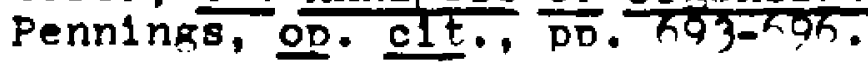


Summary of the Relationship retween Span and Centralization

Desolte a common relief that a narrow span 18 assoclated with less delegation of authority, on the part of the leader, and less participation in decision making, on the part of the follower, no statistically signiricant relationship between span and the other two variahles was found. The inanilit: of this research to detect significant correlations togetrer with the inconsistency of the findings of previous research makes the existence of such relationships doubtful.

The interoretin: tons presented so for concerned the focal associations to this stud". The following section includes rief interoretations of some supplementary relationships found as a result of the research.

\section{Supplementary Relationships}

Concise interpretetions of some relationships ietween pairs of classificetion factors and leadership (major) variahles are oresented in this part. The interoretations are ased on the information nrovided in $\mathrm{Ta}^{2}$ le 4-3.

1. The older manapers "erpressed" =oth more consideration of employees feelings and more initiation of structure. Wowever, these behavioral patterns were not reflected in their "actual" hehavior as percelved hy their employees. The age of the manager had no slenificant effect on his cholce of a part1cipative leadership stvle or on the delegation 
of authoritv to the suburdinates.

2. There was a slight tentencv among managers who were in their present joh for longer time to express less consideration and less initiation of structure. Wowever, their emplovees percelved them as more considerate and intlatino more structure.

?. Managers who had more "other work experience" were Dercelved hy their eoployees to exert more initiation of structure and more consideration.

Sumarv and Conclusion

The anplvsis of the results of tris study led to the following internretations and conclualons:

1. As the soan of subervision incressed, the manager was percelved to intiate less structure (hvoothesis III) and ie less considerate of emplovees feelIngs (hypothesis IV).

2. The relptionships expressed ahove in 1 . were found to he more algniflcant for wale respondents. This finding supgested the existence of a "sex" effect In the emplovees oerception of the leader's tehavior.

?. The leaders who initiated a hiah degree of atructure were also highly concernet with the emoloyees feel1ngs, while 11ttle direction accompanied little concern for the endovees. The positive relationship between the two roriahles held for actual (perceived) 
measurements of the hehavior as well as the belief (expressed) measurements.

4. It was proposed that, due to the lator protlem in the restaurant operations, the manager has to exert a high degree of coordination and direction on emplovees. However, coordination recomes difficult as the soan widens. This chaln of reasoning helps justifylng the reletionships discussed in 1 , ?, and 3 ahove. That 1s, as the span increased, "effective" managenent recame difficult: therefore, "oth 1n1tiation of structure and consideration suffered. In the contrar: situation, when the soan was narrow, the 1deal com 1nation of the two hehavioral patterns recome easier to ochleve.

5. The provosition mate in 4 implies that there might $\therefore$ ar oot1mum span or range of spans in the restaldrant. Th1s study found that reyond the soan of $1 E$ to 2: there was a sharo decline in woth initiation of structure and consideration. Although this finding could have imolications for the structural design of these restaurants, prescriptions are reserved unt1l future reseorch reverls more a-out the effectiveness of the leadersh10 in these restaurants.

6 The manager's actual leaderahip hehavior, along tre two dimensions of Initiation of structure and cons1deration, seemed to he unaffected br his reliefs 
ahout what comprised approprlate hehaviors along the respective dimensions (hypothesis $V$ and VI). For example, the older managers and the managers w1th less "other work experlence" exoresged more initiation of structure and more consideration. The rindings suagest that these managers put their trust in "inevolent autocracy" as an effective leadership style, wat they did not practice what they Dreached. There was a tendency among the more experlenced managers to initlate more structure and to he considerate of their emolovees feelings.

7. Contrarv to common convictions in the field, this stud: found no sianificant relationshid wetween the size of soan and dersonal particination of emplovees in decisions, or delepation of authorlt; to the subordinates (hyoothesis I and II).

\section{Suxpestions for Further Research}

Fast-rood service operations orovide an excellent environment for field researchers with organizational ehavior/theory orientation. These restaurants have many unique characteristics and many of these faceta are relatively unexplored. The management and eaplovees of these restaurants are very recestive of research activities, and it is not unreasonelle for the researcher to expect a high response rate, as was the case in this studv. The rast-food restaurants are 
recommended hy the author for a replication of this atudy to reexamine the validity of our findings, ag well as for an expansion of the present research.

The author helieves that the most important conclusions drawn from this study were the ones with possibility of practical application: 1) The suggestion of menevolent autocracy" as an ippropriate leadership style for fast-food restaurants, a rinding that could have implications for the selection of managers; and 2) the proposition that there might re an "optimum" span on the hasis of the findinga that almost all signiflcant dimensions of leadership tehavior deterlorated revond the span range of 18 to 20 . Further study 18 needed to revalldate the underlying premises of the above conclusions. These assumptions are the negative correlation between span and leadership effectiveness, and the diminishing marginal utility of increasing span after an "optimum" point. For such reexamination the future research needs to be designed to measure the "effectivenesg" of leadership.

The present atudy could also he expanded to include other variahleg which may hare an impact on the relationships under consideration. One such rariable is the level of education. Inclusion of this variable could provide for testing the argument that lanor prohlem in the restaurant industry is due to lack of education. The future research can alao investigate the possinilities of manager's heharlor being influenced $y$ his formal education. The future researcher could 
explore the possiblilty of "manager-sex" effect simliar to the "employee-sex" effect found in this study. The research design could allow for such an exoloration by increasing the number of managers, therefore the restaurants included in the sample. 
PI I IOGRAPYY

$1 \div 6$ 
PITIIOGRAPIY

\section{Dooks}

Babble, E. R., The Practice of Soclal Research, wad sworth Pülishizg combañ, Inc., Temont, Ca., 1973.

Earelas, A., "Communication Potterns in Task-oriented Groubs in D. Cartwrlart. and A. 7onder (eds.), Group Dynanics, how Peterson Purlishers, New York, 1960 , Do. 5kद- g?

Pehlina, orlando, and schriesheim, C. A., craanizational Jehavior, 11 vn and Pcon, Inc., noston, "A., lo\%.

Elau, peter, and Scott, $\because$. P.., Formal oreanizations, chendler Publisuina co., San trancisco, Ca., lá?.

Burns, Tom, and Stelker, A. W. The Kanagement of Innovation, Tavistock Puilicptions, I+A., Iondon, IonI.

Du 1n, Ro ert, "omans, $s$, Mann, $P$. C., ond Miller, :., Leadersh10 in Productivit”: Some Facts of Industrial iffe,

Dunnette, Narvin $\mathrm{r}$., Handiook of Industrlal and Crganiza-

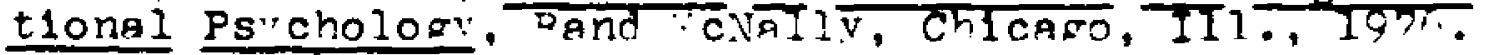

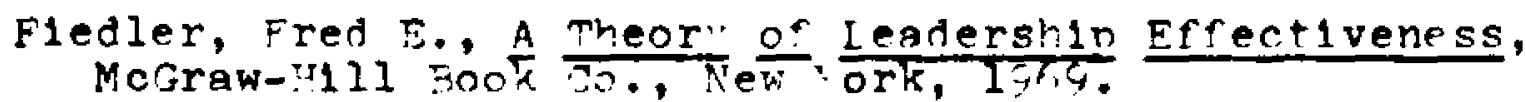
, "The Iearer's Psvcholoolcal Distance in Group Effectiveness," in D. Carturiaht and A. Zanier (eds.), Group Dynamics: Pesearch and Theory, Harder and Pow, New "ork, Igre.

Freund, John E., and Ullians, T. J., Flezentar: qusiness

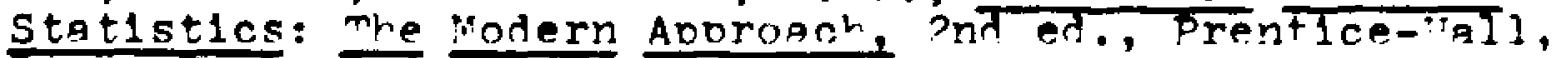
Inc., Englewood CIrfs, N.J., I9??.

Gralcunas, "A., "zelationshios in croanlzations," in I uther cerlic and I. Urrick, Papers on the colence of Adrinis-

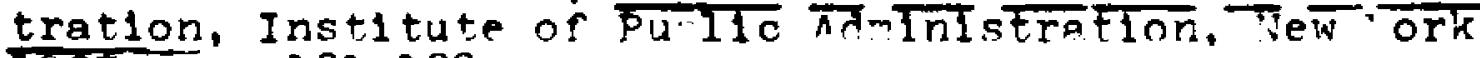
1937, Do. 191-188.

warris, 0 . Jeff, Manaplna peoole at lork, billev-"amilton Pulilcations, Tew ork, T37\%.

Yicks, Herbert G., and rullett, Ra", Craanization Theor and Gehav10.̈. Morraw-ryll Donk Co." New York, 1975. 
Co., New "ork, Iopf. Homans, reorge 0. The "tuman rroun, Harcourt prace, New vork, 1950 .

Korninauser, 4. ', Mental "ealth of the Industrlel Yorker. A Detro1t Stud, John 11 end Sons, New ork, Ighs.

L.pwrence, Paul 't, and Iorsch, Jar ?., (ets.), Stuties in Organizationsi Desion, i1chond 7. Irvit, romevost, It., 1970.

Litterer, Joseot A., The Analysis of Orzanipations, Join

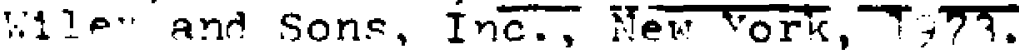

Me"ers, S. T., snd Trossen, N. E., Eehovioral Desearch:

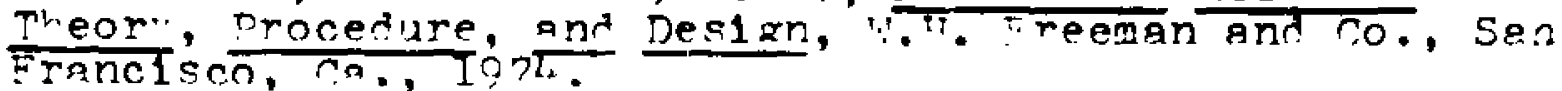

-1ller, 2. . Haizhook of Besearch Desien and Soclal Hee-

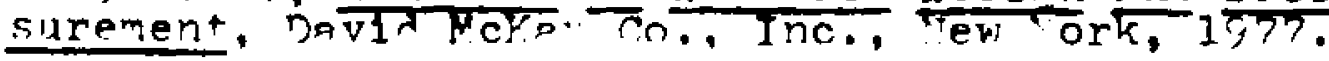

Nord, 'alter D., let.', concents and controvers: in craeniza-

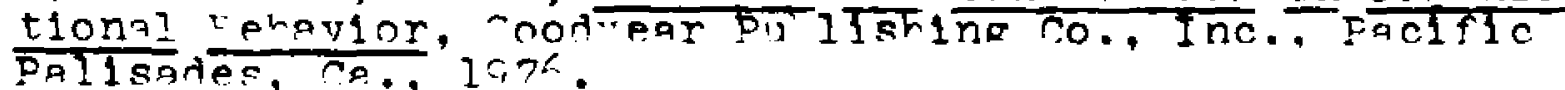

ostle, R., and Neneind, R. $\because$ Statistics in Reseprch, Iowe stote Inivers14y Press, 4mes, Iora, I93.

Perles, Fenjanin, ond sullivan, C.. Freund and N1111ams' odern Statistics (reviser er.), Prentice-iall, Inc., Enfle:oत Clifs, N.J., 19.9.

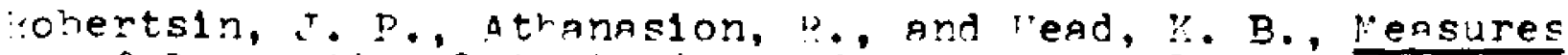
of Cccupational Attitudes and occunational CharacterisElcs, Institute of Soc1al pesearch, Un1versit" or mich1Pan, Ann Artor, M1., 107\%.

Simon, J. I.. Epsic Jeseerch Methods in Soc1al Sclence, pendom "ouse, New ork, 1969.

Teusk", Turt, Jork Srranlzations: "Ajor Theoretlcal Perspect1ves, T. F. Peacock PuhIIshers, Inc., Itasco, III., 1930.

Urwick, I.nतall $r$, The Flements of Afministration, Isaac Pitman ard Sons, Iondon, 1947.

Vroom, Victor ". Nork and "ot1vetion, John vilev and Sons, Inc., New york, Tqkl: 
Wheelwright, S. C., and Marldakias, S., Forecesting Methods for Nanagement, John Wiley and Sons, Inc., New vork, 1973.

Woodward, Joan, Management and Technology, Department of Sclence and Technolop", Charles Fouse, Iondon, 1958.

Industr1el Organizations: Theor: and Practice, oxford iniversit: Press, Iondon, iq .

wren, Daniel A., mre Evolution of Management Thought, The Ronald Press Co., New Vork, To??.

\section{Periodicals}

"A P1randelilen Prison," Nev ork Tlmes Megazine (Aor1l, 1973 , oo. 39-6io.

Entuisle, D. R., and valton, J., "Cbservations on the soan of Control," Arjinistrative Sclence Quarterly, Vol. 5 $(1961)$, DD. = क?

Fledler, Fred, "Enalneerlang the Jo" to rit the "anager," "arvard nusiness neview, 51 (19\%5), no. 11'-1??.

Fink, Clinton F., snd Thomas, ENtin J., "Effects of rouo Size," Psvchologlcal iullet1n, vol. Ko, l: (19t 31, no. $371-384$.

Fleishman, Edwin A., "The Measurerent of Leadersh10 Att1tude in Indistry," Journol of 4polled Ps'chology, Vol. 37, ?

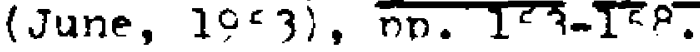

- "I eedership climete, "uman Relation Tracking, and SuDervisory Rehavior," Personnel Psychology, ', (Iy:3" DD. ?ri:-???

Fleishman, Edwin A., and Harris, E. F., "Patterns or Leadership pehavior Related to Fnployee Crilevance and Turnover," Personnel Psycholoxy, $15(19,2)$, no. $4-3$.

Forehand, G. A., and G11Ter, D, "Fnvironmental Varlations in Stuties of Crapizational Behavior," Psycholoalcal zulletin, $\Rightarrow 179$, on, Xl-39?.

"age, Jerald, "An axlomat1c Theor" or Cragnizations," Adrinistrat1ve Sclence 2uarterly (Decen er, 1rif $)$, oD. 299-350.

rage, Jerald, ond aleen, "1chael, "gelatlonstlos of centrelization to cther structural pronerties," ndministrative Sclence zuarterl., 1 ? (Eune, 1467$)$, Dn. $77-7$. 
Heller, F. A., and vulk, G., "Particloation, Manageriel Declsion Makina, and situational Varlatles," Organizational Dehavior and Yuman Pertormance, L (19K4), bo. 377-?41.

Hemph1ll, John F., "Relations Petween the size of the Soan and the Pehavior of "Suberior I eaders'," Journal of Soclal PS"chology, 32 (19.50), pD. 11-??.

rakson, D. E., Pugh, D. S., and Phesev, D. C., "cperetions, Technolor", and Croanization Structire: an Fmolrical peappra1sel," Anministrative Solence Quarterly, If (19\%:9!, DD. $44-54$.

:ouse, kotert, and N1ner, John F, "Merplne Vanaqenent and chavioral Theory: The Interaction hetween Span of control and Groun size," Atministrative Science juarterl\%, 1l: (1949), DD. $4: 1-4,3$.

Youse, Bo ert J., Fllle", A. C., and Kerr, S., "Relation of I eader consideration and Inttiation of structure to $P$ and D Subordinates" Satisfaction," Administretive Sclence Quarterly, 16 (15,7)! 50. 19-30.

"ulin, Charles I., and 2loo", ". Q., "Jo" Enlargement, Ind1v1lial nifferences, and lork resoonses," psychologlcel Bullet1n, $69(10.9)$, on. $41-55$.

Farmel, Earera, " a challenre to Traditional lethods and Assizntions:" Acatem: of "anpgement qeview, No. 3, Vol. J

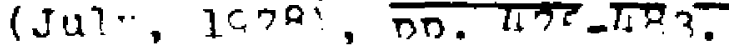

Klonis, D., "oes Power Corruot?," Journal of Personal1t: ene Soclal Ps.chology, th (1973, no. 3r-LI.

Lahrence, Pall ?., and Iorsch, Ja $\because$, "refferentiation and Intearation in comblex Cranlations." Adninlstrative Sclence Quarterly, 1? (19\%7), po. 1-47.

Yass, "enr' S., "Fersonal and froud tactors in Leader's social Perceotion," Jolurnal of Ahnormal and Soc1al Pstcholog:, l:5 (1950), pत. दान 3 .

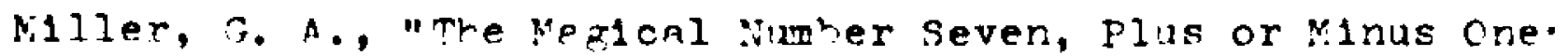
Some I1mits on Cur Caogclt:" of Processing Information." Dsycholoolcal zevlew, $A 3$ (19ak:, Dp. S1-G?.

Morse, Nanc:, and Relmer, Everett, "The Exnerlmental Change of a Major Cranizational Variable," Journal of Abnormal and Soc1al Psicholog:, $\because(19$ er), oo. Th-139. 
Myers, Scott M., "Conditions for "anager "otivation," "arvard Fusiness peview (June-Fehruar", 1966), op. 4?-71.

Pennings, Johannes, "Measure of Craanizational Structure: A Nethodoloatcal itote," American Journal of Soclology, ? "ol. 79 (1073), no. KRF-7n?.

Porter, I "man ' $V .$, "A Stud" of Percelved Need Satisfaction in Bottom and Nidile Management Jobs," Journal of Applied Psycholog*, Le (1961), DD. 1?3?-12x,

Porter, I "man $v$. , and I 9 ler, Edwerd $5 .$, "Froperties of cronnization Structure in Relation to Joh At+1tides and =hovior," psvchological Dulletin, ill (1cr:i, oo. ?3-:1.

Pugr, D. S., stokson, D. T., "ininfs, C. F., and Turner, C., "Dimensions of Cranizational Structure," Adminlstrative Sclence puerterly (June, 1048), Do. G.einc

Schmidt, warren "., ond monrertalm, Tohert, "i:o" to choose ? Ieadershin "Atern," Harvard insiness Heviev, No." $x^{\prime}(19=8), D^{-} \cdot r-101$.

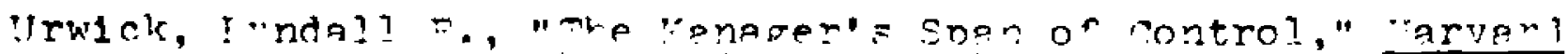
Businese Review, 2l: (1,r), nn. $2-4.7$.

:!tyte, "1111am ". "m:p anc1n "tructura of the zestaurent,"

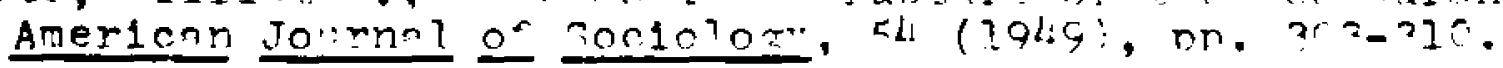

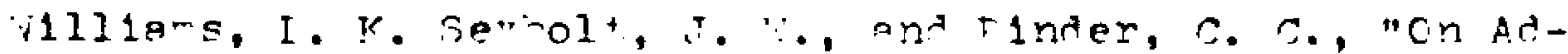
minlstering aestionnalres in Crognlzational rettings," Dersonne? Frucholosy, 'rol. pa (1974), pn, Graln?.

Vlorth., James C., "Crganloptlonal Structure and Emoloyees "orel," Americon Soclologlcal Pevier, is (10.0), oo. 1:9179.

Zaccarel11, "erman E., "Insn1rinr rood Manazemert," Scrool Food Service Journal, Seotem er, 1979, on. Et.

\section{M1scellaneous Pub?1cations}

Fleishran, Edwin A., "I eodershid Cl1mate" and Supervisory ehavior, Personnel Fesearch onrd, The ohio state University, Col indus, chio, 1751 .

"ealy, J. ". Executive Coordination and Control, A rureau of Pusiness Tesearch Vonograph, The OhTo State Universit: Columbus, ch10, $29=6$. 
Stogd1ll, Ralpr M., Leadersh10 Ahstracts and D1bllography 1904-1974, The crio State Universit., CoIlege of Administrative science, columbus, oh1o, 1976.

- Manual for Leader Dehavior Description question-

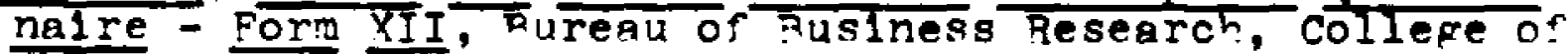
Commerce and Adminlstration, The chio state University, Columbus, orio, Igh?.

Stogd1ll, Baloh $r$ and Coons, A. E., Ieadershlo zehavior:

Its Description and Measurement, Research Monograph To.85, Eurepu of Eusiness Research, The chio state University, Columbus, ohio, icr.7. 
APPENDICES

$11=$ 


\section{APPENDIX A \\ EMPICVEE OTESTIONAI RE: \\ S' BSCAIES AND SCORING FORMA ms}




\section{EMPLOYEE QUESTIONNAIRE}

\section{DIRECTIONS :}

a. READ each 1 tem carefully.

b. TrIT a hout how frequentlv your subervisor engages in the behavior described ry the 1 tem.

c. DECIDE whetiver he/she (A) alwais, (B) orten, (C) occasionally, (D) seldon, or (E) never acts as described by the 1 ter.

d. DRAli A CIRCLE around one of the five letter (A B C D E) following the item to show the ansier vou have selected.

$$
\begin{aligned}
& A=\text { Always } \\
& D=\text { often } \\
& C=\text { Occasionally } \\
& D=\text { Seldom } \\
& D=\text { vever }
\end{aligned}
$$

e. Mapr "our answer as shown in the examble -low. Example: Cften acts as descrip........... A C DE Examble: Never acts as descried........... Example: occasionally acts as described........ $O=E$

INI TIATIO:: CF STRUCTURE SITSCAIE

1. Iets emplovee knov: what is expected of ther.... A $P 2 D E$

2. Encourages the use of set wa:s of dolnt thines. A $C D E$

3 . Tries out $h 1 s /$ her 1 iees in the group...........

4. Makes his/her attitures clear to the rroud..... A P C D E

5 . Describes what shall be done and how $1 \mathrm{t}$ shall be done.........................

6. Assigns group mem ers to particular tasks...... A P C D E

7. Schedules the work to done............. i C DE

8. Makes sure that his/her part in the groub 18 understood $\mathrm{ny}$ the emblovee................A $\equiv$ C DE

9. Keeps fixed quality of performance...........A = C DE

10 Asks that embloices follow rules ant requlations..

1. Is friendly and easy to talk to...........A P C D E

?. Does 11 ttle thines to make $1 \mathrm{t}$ pleasant to work

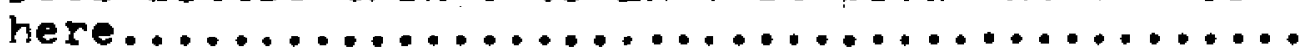


3. Puts suggestions made by the group int oocration A E C DE 4. Treats all employees as his/her equals........A $P$ C D E

5. G1ves advanced notice of changes........... A F C D E

F.* Keeps to $n 1 m s e l f / h e r s e l f \ldots . . \ldots \ldots \ldots \ldots \ldots \ldots$ A P C D E

7. Looks out for personal welfare of employees... A F C D E

8. Is willing to make changes............... F C D E

9.* Refuses to explain his/her aotions........... A . C D E

10. Acts without oonsulting the group............ A C D E

SCORING FOFMAT. All 1 tems of the above sunscales, with the erception of the marked 1 tems (*), are scored.

$$
\begin{array}{lllll}
A & B & C & D & E \\
5 & 4 & 3 & ? & 1
\end{array}
$$

Starred 1 tems are scored in the reverse direction.

Source: A. M. Stoad111, Leader pehavior Desoription questionnalre - Form XI, ohio state Univeraitv, IG'3.

\section{CENTRAIIZATION: ACTIAI PARTICIPATION}

DaA:? A CIñCl Fround one of the flve letters (A E C D E) followine the 1 tem to show the ANSWE? vou have selected.

$$
\begin{aligned}
& A=\text { Alwavs } \\
& B=\text { Often } \\
& C=\text { Occesiona } 11 \% \\
& D=\text { Seldom } \\
& \Phi=\text { Never }
\end{aligned}
$$

1. Tow frequently do rou usuelly participate in $A P C D E$ the decision to hire new omployees?...........

2. How frequently do vou narticloate in the dec1sion on the ororotion of any of the employees?. A $I S E$

3. "ow frequentl" do you participate in the decision on the adoption of new rules and policles? $A$ : $C D E$

4. How frequently do you oarticloate in the decisior on the adoption of new programs (Sales Contests, etc.) ......................... C D

SCORING FORMAT: Itens of thls suhgcale are soored:

$$
\begin{array}{lllll}
A & B & C & D & E \\
5 & 4 & 3 & 2 & 1
\end{array}
$$




\section{CENTPALIZA CION: FTERARCYY OF AUTMORITY}

a. READ each of the following statements carefully.

b. Show your AFREEMENT with the statement by DRAWING A CIRCLE around:
(A) If you STRONGLY AGREE w1 th the statement
(D) 1 y you AFREE with the statement
(C) if vou TISAGFEE with the statement
(D) if YO'd STRCNGIY OISACREE with the statement

1. There can he 11t.tle action here unt1l the supervisor adproves a decision..............

2. A Derson who wants to make his/her decision would be quickl. discourager here........... \& \& $C$

3. Ever: small natter has to re referred to someone higher uo for o final declalon.............. . C $D$ 4. I have to ask y: noss hefore I do eijost an ${ }^{\prime}$ thing.............................

5. 4n decision I moke here has to have mi hoss. approvel...........................A $R C$

SCOFIn: FCOMAm: Items of this su scole are scored:

$$
\begin{array}{lll}
1 & =5
\end{array}
$$

Source: Centralization sul scoles are adobted from the scales found in "Relationshid of centralization to other Structural Projerties," hy Jerald Hage and $Y 1$ chael Alken, Aduinistrative science Guarterly, Tol. 1\%, No. 1 (June, 197: 
APPEITDI Y $P$

STFYTISOE CFINICN QUESTIONAIPE:

STSCAIES AUD SCOPIUJ FCRMATS 


\section{SUPEAVISOR OPINION QI'ESTIONNAIRE}

\section{DIRECTIONS :}

a. READ each 1 tem carefully.

b. TIINK a out how frequently vou, as a supervisor, should engage in the hehavior described by the 1 tem.

c. DECIDE whether vou should (A) always, (B) often, (C) occasionall: (D) seldom, or (E) never act as descrimed ry the iter.

d. DPAi! A CIMC: a roind one of the flve letters (A D C I E) folloking the 1ter. to show the answer :o'd have selected.

$$
\begin{aligned}
& A=\text { Always } \\
& D=\text { Often } \\
& C=\text { Cccasional } 1 . \\
& D=\text { Seldom } \\
& \bar{D}=\text { "ever }
\end{aligned}
$$

e. :AgY. Your answer as shown in the exomole elow.

Example: Cften act as descrited.................

Example: Never act as tescri ed............. A = $\bar{C} \equiv$ Examnle: Cocasional1: act as descrited.......A O (C) $D$

\section{INITIATICR CE SMPUTTED}

1. Iet emolorees know what is expecter of them... A 4 C $D$

2. Encourage the use of set wavs of doing things. 4 D $D E$

3. Tr. out rour 1 teas in the groun............... $D E$

1. Make vour attitide clear to the rroub.........

- Descrihe what shall re done and how 1 t shall

re done.......................................

6. Assion aroun nembers to barticuler tasks..... A I C D E

7. Make sure that vour part in the group is

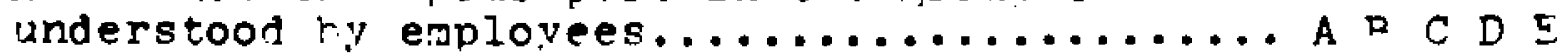

8. Schedule the work to te done................ A C D $E$

3. Keep definite standards of performance........

10. Ask emplo: ees to follow standards and regula-

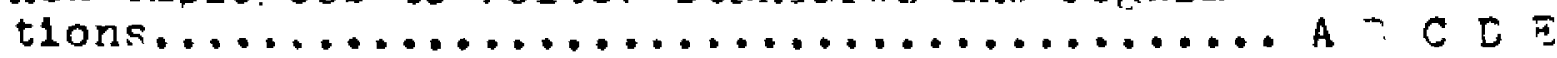

CONSIDEZATICN

1. Le frlend $1:$ and epproachable.............. A $\mathrm{E}$. $\mathrm{E}$ 
2. Do l1ttle things to make 1 t pleasant to work A B C D E

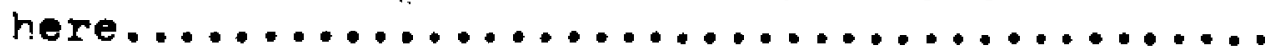

3. Put surgestions made by the group into operaration................................ C $F$

4. Treat all emplovees as your equals............ A P C D E

5. Glve advanced notlce of changes............. 5 C D E

G. Keep to yourself............................ C D $E$

7. Look out for personal welfare of emplovees.... A P C D E

8. De w1lline to make changes................ P C D E

G.* Refuse to explain your sction..............

10. Act without consulting the grouo...........

SCCRIN FCPYAT: 4II 1 tems of the a-ove two surscales, except the 1 tems marked (*) ore scored:

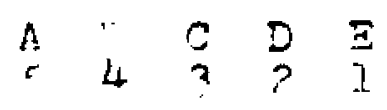

3 tarred items are scored in the reverse direction.

Source: 3. M. Stogd1ll, Ieader Echavior Description auestionnalre - Form XII, ohio State TnIversit:, 
Tí I

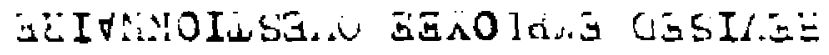

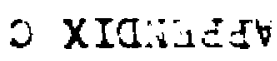


DIRECTIONS

- READ bach ototonent earerully.

b. DECIDE whether your uderrisor, anager, (A) alwaya, (D) often, (C) occeslonaily, (D) weldow or (a) neter acte as deserlbed by the tatement.

c. DRAit A CIaLE around one of the five letters ( A E DE following the ateterent to show the angwer you have selpoted.

$$
\begin{aligned}
& A=\text { Always } \\
& E=\text { orten } \\
& Q=\text { Occaslonally } \\
& D=\text { Seldom } \\
& E \text { - Never }
\end{aligned}
$$

Example: orten acts as deacribed .........A@ $\mathrm{C} D \mathrm{~g}$

Eramplo: Nerer acta as descritod ..........A $\Xi C D$ C

Example: Cccestonally ncts a deacrired .....A $\mathrm{A} G$ $D E$

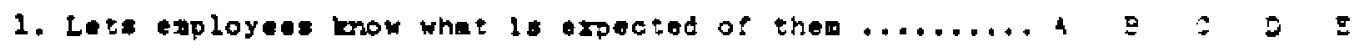

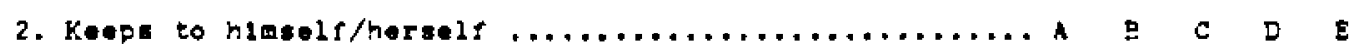

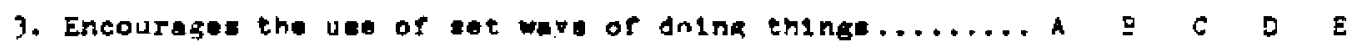

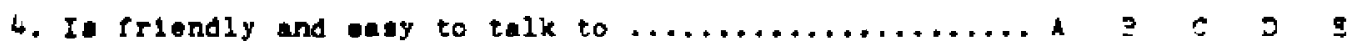

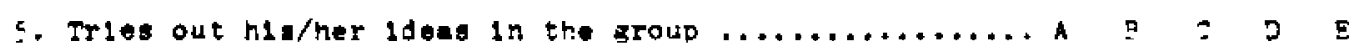

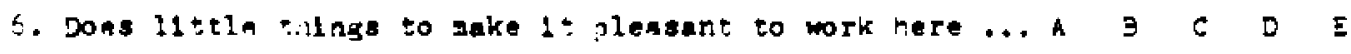

7. Yakes $\mathrm{mlg} / \mathrm{her}$ attitude clear to the group $\ldots \ldots \ldots \ldots \ldots A$ D $C \mathrm{D}$ E

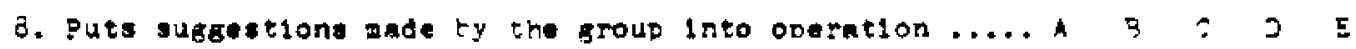

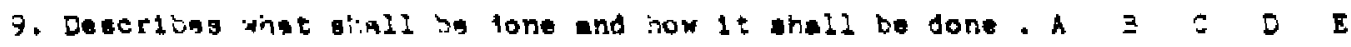

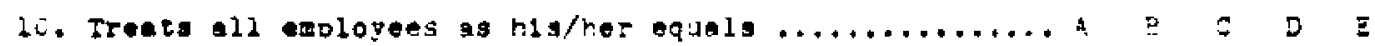

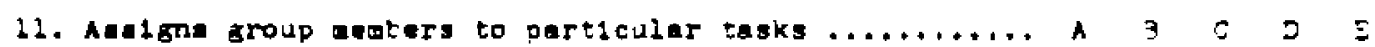

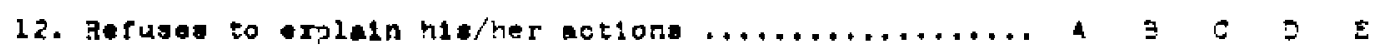

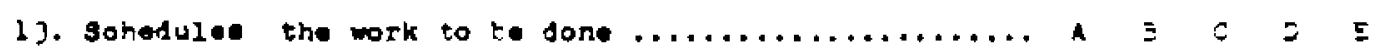

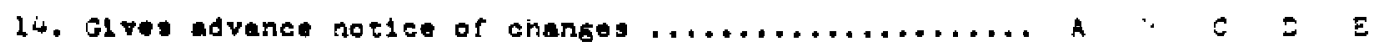

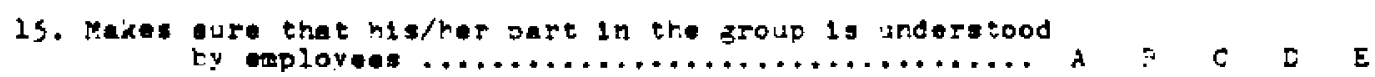

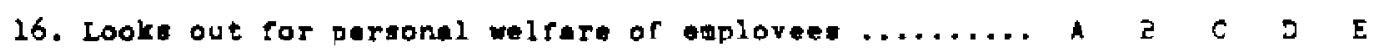

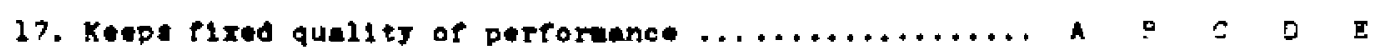

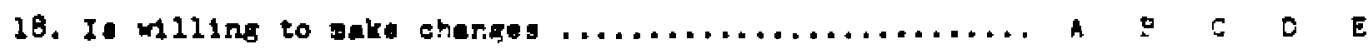

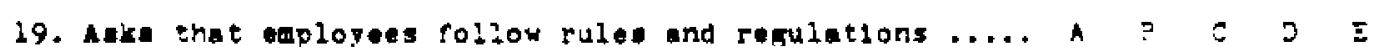

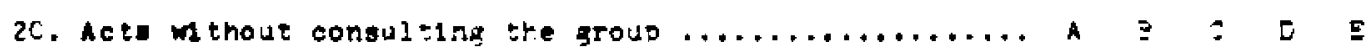


a. DRAW A CIRCLE around one of the rive lotterala $\mathrm{P} C \mathrm{O} \mathrm{E}$ f following the gtatement to show the entwer you hate eelocted.

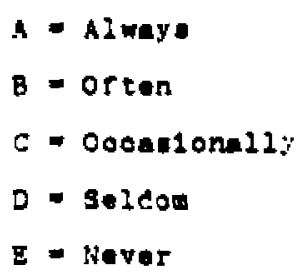

Examplei crten part1olpate in the deolsion s. deacrited .................... $Q \subseteq$ D E

Exaple: seldom participate in the deoluton

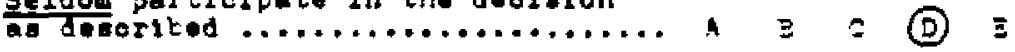

Example: Never partialpate in the decialon e doscrited ................ $\mathrm{A}=c \mathrm{D}$ (

21. Fow frequently do you partielpate in the decision

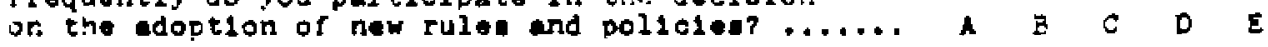

22 . Yow frequentzy do you participate in the deciston on the dootion of new programe?(sales contegts,teto.iA $\quad C \quad D \quad E$

23. Fow froquently do you latieliy vartiolpte in the

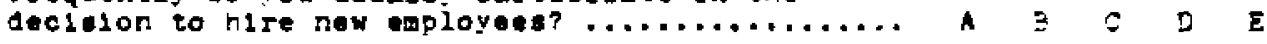

24. Sow rrequently do jou particlpate in the declision

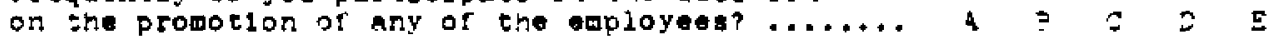

DI AEC:EC:S

a. IEAJ encil of the rollowing stetemente carofuliy.

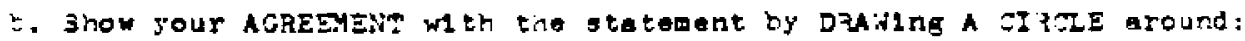

(A) If you STROHGLY ACREY id th the statement

(a) if you AGREE with the stateront

(c: If you DISA JREE with the statedent

i J) If yuU STRONGLY DISAGREE with the stetegent

Example: Agree with the statedent ......... $\Theta \subset D D$

Eramplo: gtrongly disagres $w 1$ th the statesent.A $I=$ (D)

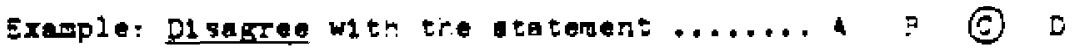

25. There oen te 11 ttle action here until the supervigor

eluntoles decision .......................

20. A person wo wents to Jakg ila/her own declsion would

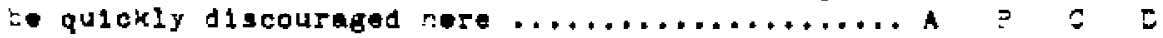

27. Every mell motter has to lie recerred to sogende

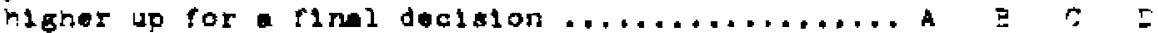

28. I heve to esk my roag efore I do almost anything .... A $\mathrm{E}$ C $=$

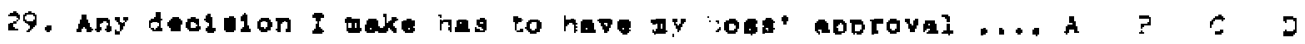

Plenge answer the follow1.3y jitestons:

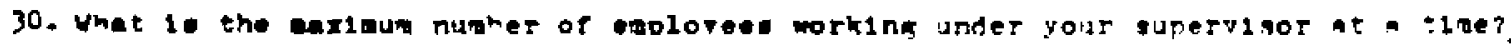

31. Your Age

32. Your $30 x$

33. Sow long in :n1s jot?

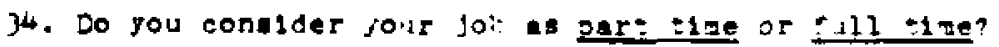

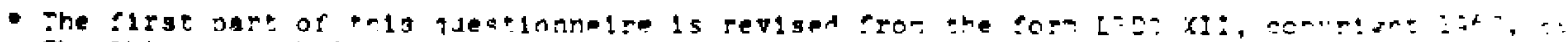
the chlo 5 tate intversi?. 
A.PPENDIX D

REVISED SUPERVISOR OPINION QUESTIONNAIRE 
*. AEAD anch otetowent omreruliy.

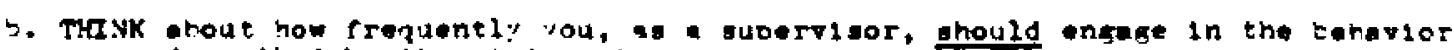
deoclsed ry the staterent.

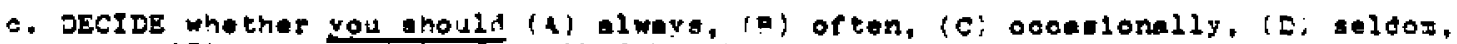

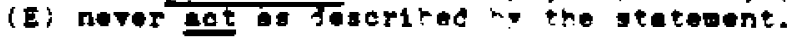

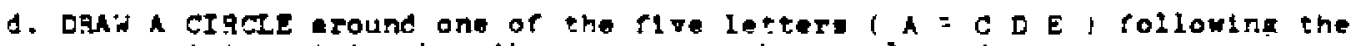
atetement to ahow the anawer vou have selected.

$$
\begin{aligned}
& A \text { - Almays } \\
& \rightarrow \text { - crten } \\
& \text { c 000nitistiz } \\
& \text { D Seldon } \\
& \text { E Never }
\end{aligned}
$$

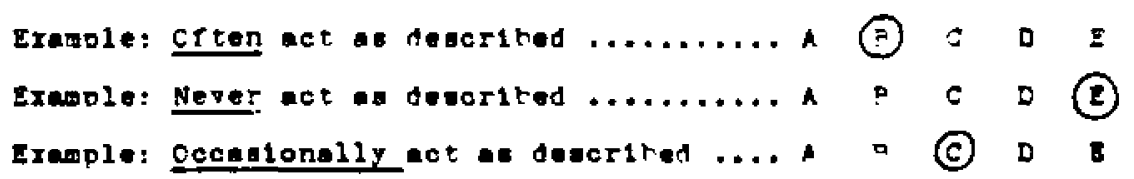

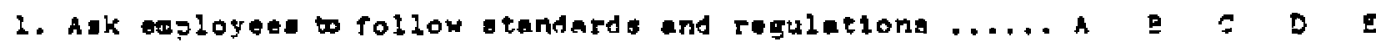

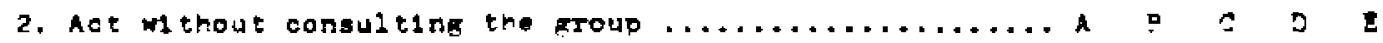

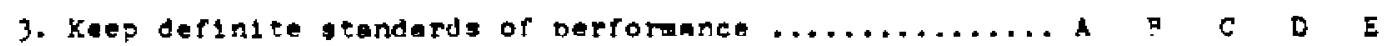

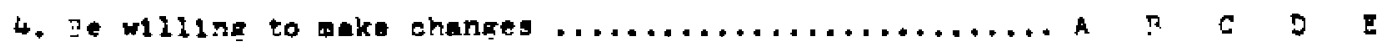

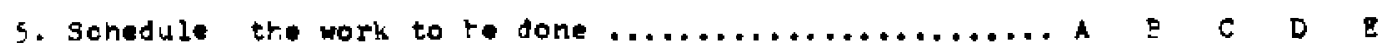

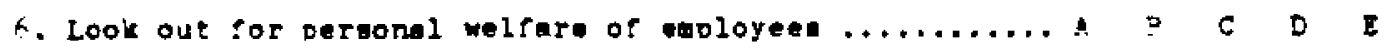

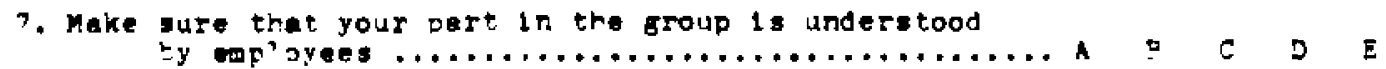

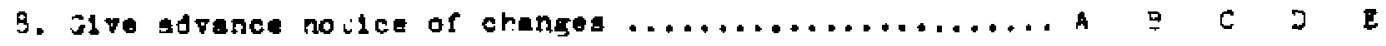

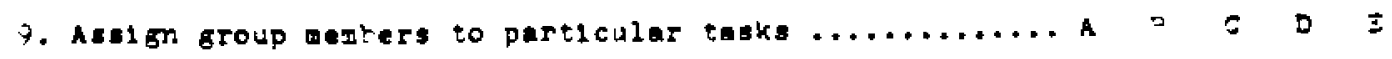

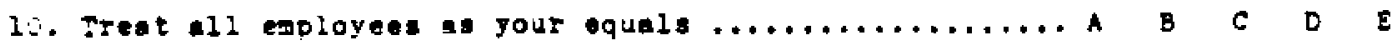

11. Defcrite what gall sone and how lt ahell te done... A $E$ C $D E$

12. Ket to yourgelt $\ldots \ldots \ldots \ldots \ldots \ldots \ldots \ldots \ldots \ldots \ldots \ldots \ldots \ldots \ldots \ldots$ I........... $\mathrm{D}$

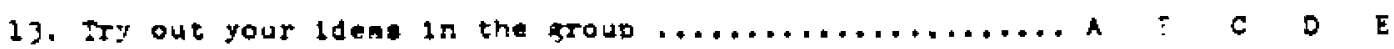

14. Put auggeationa pade ry the groud 1 nto oderation ...... A 9 C D E

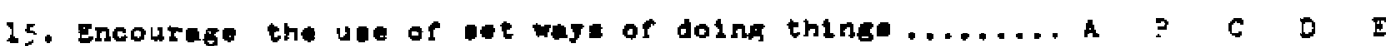

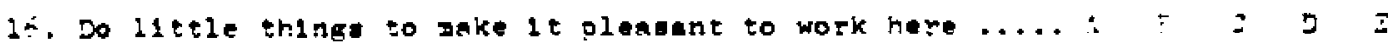

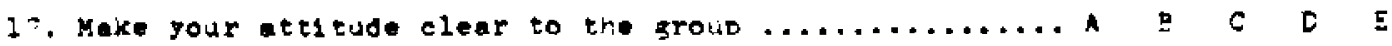

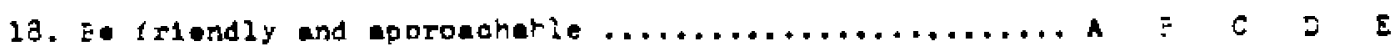

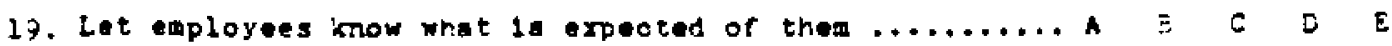

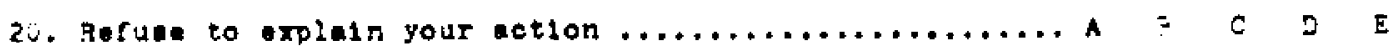

Ploas answer the rollowing gueationg:

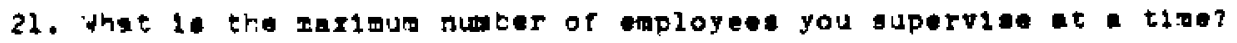

22. Your uge:

23. Your sex:

24. How long $1 \mathrm{n}: h 1$ : Dos $1+10 \mathrm{n}$ ?

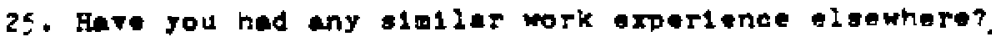
how long? If yea for

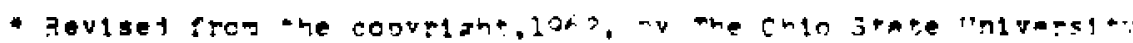




\section{APPENDIX E \\ COVER LETTER POR THE \\ SUPERVISOR OPINION QUESTIONNAIRE}


College of Business Administration

\section{Dear Manaper:}

I would like to request vour assistance in a research program which is a part of a toctorel dissertation in the Management Deoartment, Ioulsiana state Unlversity. This Fh. D. dissertation research study deals kith work orolins 1 r senerol, and does not degl tith an: bartlcular comban or individia? nerson.

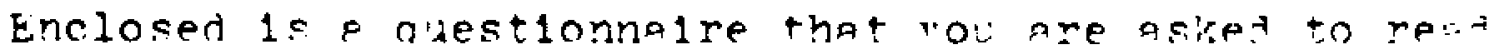
and answer. vour resconse to this auestionnolre $1 \mathrm{~s}$ vital te

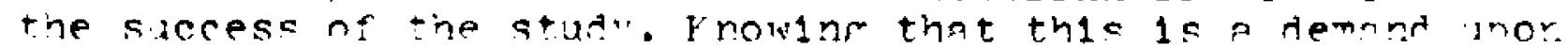

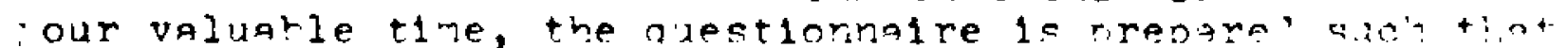
it sholld not toke more than ten alnites of vour time. It $1=$ lmoortart that rou answer nli of the allesions since incomnlete nuestionnalres carnot re used for the nirnose of the stid.

The dote for this resencoin 10 gotherot in nort throwm:

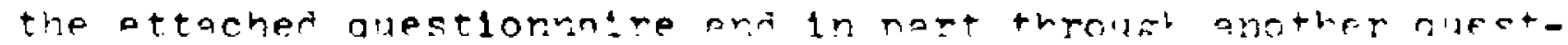

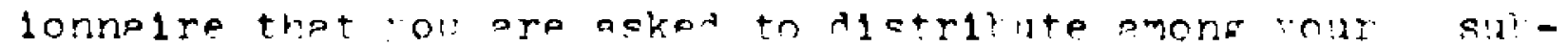
crdinates. Since the two tine of the aluetionnplres are complementory, it $1 \mathrm{~s}$ imortont that rour sulordinates ansuer the questions bertineat to vour sinervision, and not sidervision? of other supervisors, if there are sq" onr ता etritation $0^{\circ}$ the auestionnolres nons :olir subordinates and the emnhorio that they should keen vour sunervision in wint, fren answertro the ouestions,will nssure the proner collection of $A+a$.

Since it is not the purnose of this reseprch to stide ar. particular orpanization, there $1 s$ no name or 1ientification mark that would reverl the 1ient1t" of the resnonient. vour resconses, alone with the resmonses of other norticinants, w1 I te collecter. $t$, the researcher hinself to ascilre the confliertial1ty.

You will te nrovided f cons or the rintines of this stid.. Your narticination and cooneration in this research nroject 10 very imoortant factor which ras a sifnlficant imnact loon the success of the study, and the researcher will le preatful for your assistance. Please feel free to contact me if vou have an: further olestions.

sincerel",

Foar nerakhshan Ph. D. Candidate Management Department. Ioulsiana State riniversit. 


\section{APPENDIX $F$ \\ COVER IETTER FOR TTR \\ ENPLOVEE QUESTIONNAIRE}


College of Business Administration

Dear Friend:

I would like to ask for vour cooperation in e research program which deals uth wore sroums in general, and does not deal with any nerticiler comnany or individual nerson. This study $1 \mathrm{~s}$ a part of $\mathrm{Th}$. D. dissertetion $1 \mathrm{r}$ the Vnnarenent Department, loalsians state Iniversit.

Fere 1 a questionnsire thet "oll are asked to rend and answer. Vour resnonse to $3 ? 1$ of the niestlons 15 necessarv fothe success of thle star. Flense do not leave nn allestion unanswered. The nuestionnal re is nrenaren slict thrtit shoul not Eake Jore than ter minutes of our time.

In answerlno nan af the auestlons $\because 0$ n need to rementar how your sunervisor, mnnacer, acts. Ir "ou worle under severil mangore, recall tive notlons of crl one sunervisor. the one who distrif ited the questionnalro.

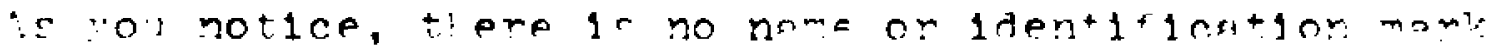

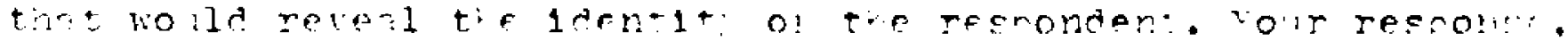

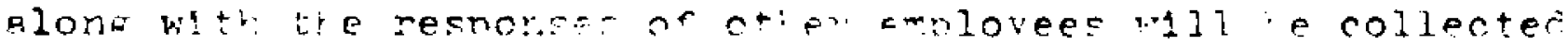
In tallot : oy " the resforcier impele to fecire contidential1t:.

oir nerticiration ant coomeratio: in this research oroject is ver. Imnortart for the siscess of thic stur, ant is dees!" annreclate".

Sincerel:

boat Demelishar

Ph. D. Condidate

Desatzent of panarerir:

anisiona state ind ve: : 
APPENDIX G

SELF-INSTRUCTED ENVEIOPE FOR TIT DMPIOVEE QITESTIONRAIRE 


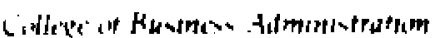

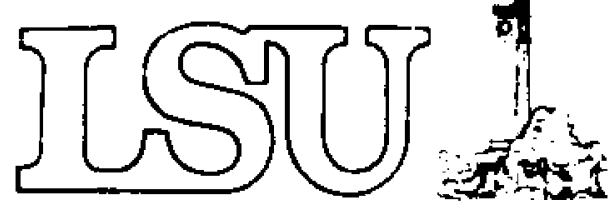

LOUISIANA STATE UNIVERSITY

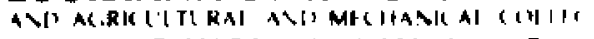

BATON ROLGT. IOLLISIANA TIRI

1. Answer all the auestions

3. Fold and nid the questionnalre in this envelope

?. Seal and tron this envelone in the rallot tox 


\begin{abstract}
APPENDI $X$
PERMISSIC:: DERTESTS FCT TIF

USE OF QUESTIONNAIRE S!T SCALES

AND SITSSELENT AITTPORIZATIONS
\end{abstract}


LOUISIANA STATE UNIVERSITY

AND AGHICULTURAL AND MECHANICAL COLLEGF

DATON ROUGE - LOUISIANA 70003

Collegc of Business Administration

DEPARTMENT OF MANAGEMENT

May 23, 1979

Dr. Michael T. Alken

Departaent of Soclolog:

University of Wisconsin, Madison

Nadison, Wisconsin 53706

Dear Professor Alken:

I ar writine to request your penission to use "The Index of Particloation in Declsion "aking" and "The Index of Hierarchy of Authorlty", teveloned by you ano Dr. Hage, in my dissertation. These Indices adoeared in "Relationship of Centralization to other structural Properties" Administrative Sclence Quarterly, vol. 12, no. I, June 1967: pp.78-79. I would appreciate if you also provide some information on the reliatility of these questionnalres since no such information was provided in the referred article.

to me.

Your help in regards to this request has a great value sincerely,

Foad Derakhshan Doctornl student 


\section{University of Wisconsin-Madison}

Mr. Foad Derakhshan

Doctoral Student

Department of Management.

Louisiana State University

Baton Rouge, Louisiana 70803

Dear Mr. Derakhshan:

Given that the scale you mention are published, you of course need no permission to use them. Bob Dewar, now an Assistant Professor at Northwestern University School of Business, calculated the reliability of these scales for three successive uses of them. I suggest you contact him for this information.

Sincerely yours,

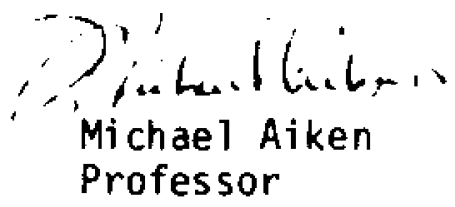

MA:sm 
LOUISIANA STATE LNIVLRSITY

AND AGRIGUITURAL AND MECHANICAL COLLIGE

BATON TOUGE . LOUISIAINA POEO3

Collegc of linteints Adntinistration

OEPGHTHENT OF MANAGEIMLINT

May 23, 1979

Dr. Jerald T. Hage.

Deparinent of Soclology

University of W1 scolisin, Medison

Madisor, wisconsin 53706

Dear Profestor Hage:

I am writing to ask for your perriselon to use "The Index of Participation 1r Declsion "aling" and "The Irdex of H1erarchy of Author1t:", develored ry you and Dr, Aliken, 1:: "'y disscrtation. These indices appeared in "Relationship of Centrallzation to other Structural properties" Adralnistrative Sclence Quarterly, vol. 12, no. 1, June 1967:pp.?8-79. I wolld appreclate if you also sent me some information on the rel1atility of these questionnalres since no such information was provided in the rererred article.

I truly appreclate your help in regards to this request.

sincerely,

Foad Derakhshan

Doctoral student 


\section{UNIVERSITY OF MARYLAND \\ COLlEER PANK 20742}

DIVIEION OF BeHAVIORAL AND social ceIINCES

July 13,1979

Mr. Foad Derakhshan

Department of Manageme.ut

Loulsiana State University

Baton Rouge, Loulsiana 70803

Dear Mr. Derakhshan:

We received your letter on June 14,1979 and then $i t$ was forwarded to me in the south of France so please excuse the delays but they have been unavoldable.

of course, you may use this index. Good luck in your research.

As ever,

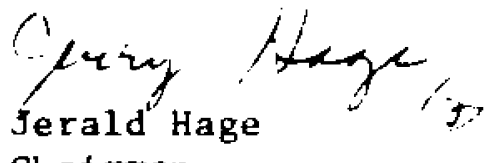

$\mathrm{JH} / \mathrm{gg}$ 
College of Business Administration

$$
\text { May 23,1979 }
$$

D1 rector, Subport Services, 210 Hapertv Hall

College of Administrative icience

The chio state Inlversit."

1725 college Rr.

colombus. Chin 4371 .

DeAT S1r:

I Am writing to request your permission to use a part of the "Leader Fehavior Descrintion QuestionnolreForn XII', 196? copyriaht in my doctoral dissertation.

vour held in regards to granting the perrission is truly appreclated.

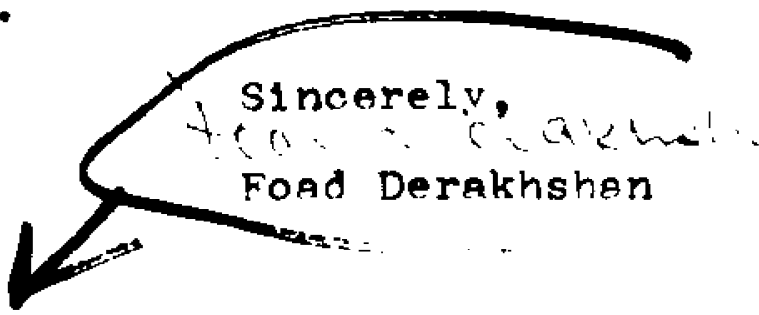

PERMISSION IS GRANTED TO USE OUR LBDQ XII, IN ACCORDANCE WITH OUR POLICY, ATTACHED.

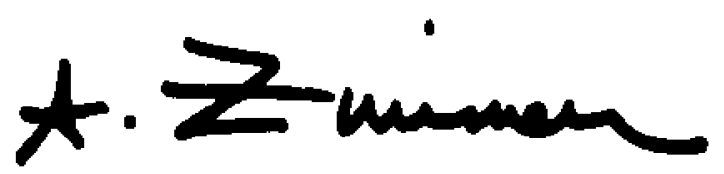

ADELE ZIMER

MAY 30, 1079

SS/CAS/THE OSU 
Concerning the Leader Behavior Deocription Questionnaire and Related Forms

Permiesion 18 granted without formal request to use the Leader Behavior Deacription queationnalre and other related forma developed at The Ohio state Untreralty, oubject to the following conditions:

1. Use: The forms may be used in research projects. They may not be used for promotional activities or for producing incone on behalf of Individuals or organlzations other than The Chio State Untversity.

2. Adaptation and Revision: The directions and the form of the itero may be adapted to specific oftuations wen such steps are considered desirable.

3. Duplicetion: Sufficient coples for a specific research project way be duplicated.

4. Incluaion in discertations: Coples of the questionnaire may be included in theses and diesertations. Permission is granted for the duplication of such diaertations when filed with the University Mlcrorilms Service at Ann Arbor, Mlchigan 48106 U.S.A.

5. Coprright: In granting permission to wodfy or dupl1cate the questionnalre, we do not murender our copyright. Duplicated queationnaires ard all adaptations should contain the notation "Copyright, 19--, by The Oh1o State Untversity."

6. Ingulries: Commicetions should be addressed to:

Center for Business and Econonic Research The Chio State University 1775 South College Road Columbus, On10 43210 U.S.A. 


\section{APPEINDIY I}

\section{CORPEI ATION NATRIX}




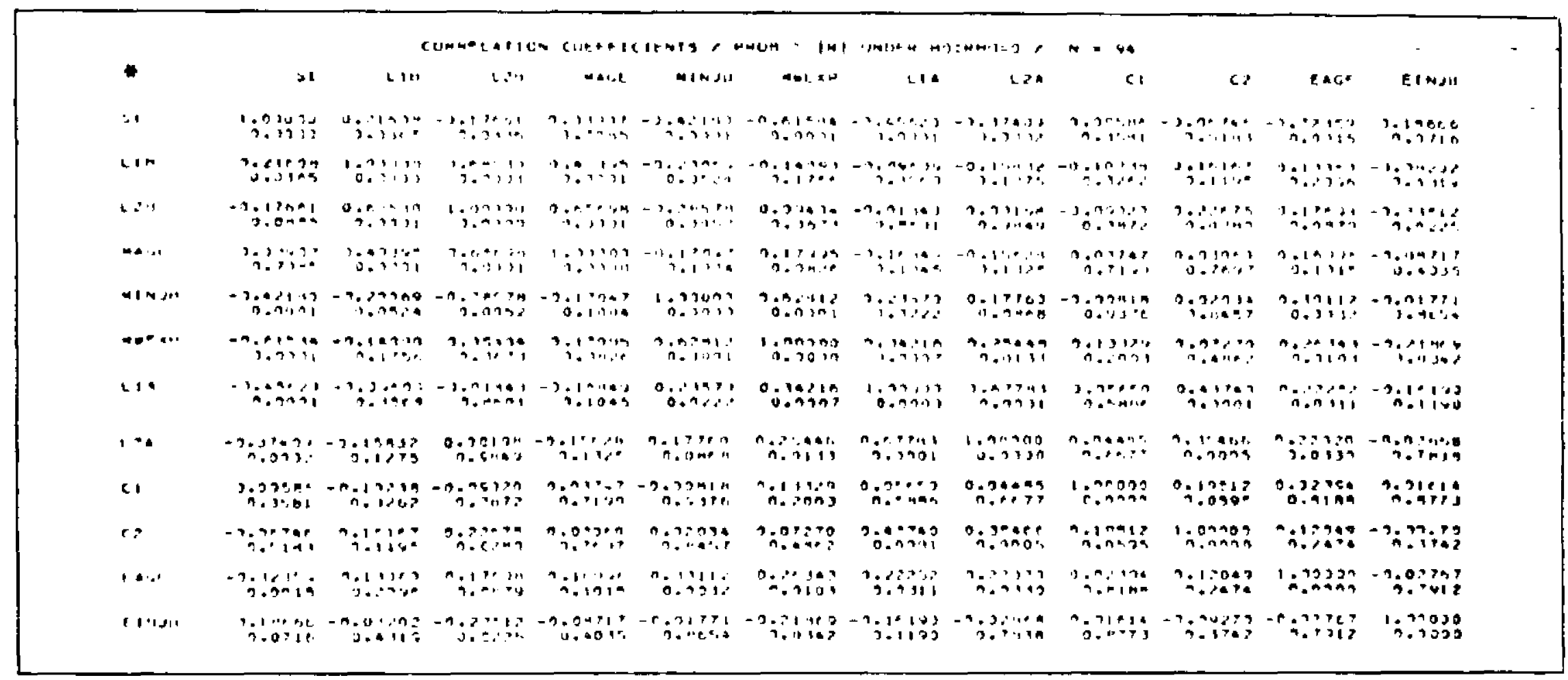

* liefer to Ta le 4-l (pare 4\% for the complete nane of tip variorles corresponding to the codes in the rntmix a ore. 
VI $m$ A

Foar Derakhshan was horn in Ahvaz, Iran, on Fehruary 25, 1049. He greduaten from Yhararmi H1 th School, Tehren, with a concentration in mathematics. Then he servet in the Iranien armed forces. Itoon combletion of his mil1tar. service, he enteret Jehran rusiness college, where he recelved a gachelor iearee in ousiness science. In 1974, he entered the M.P. A. orormam at Ioulsiana state University (:.s.T.), Pator ?oize. After recelvinf his master decree in $197 f$, he continued sturies tomart o ph. D. Hegree in ranace-

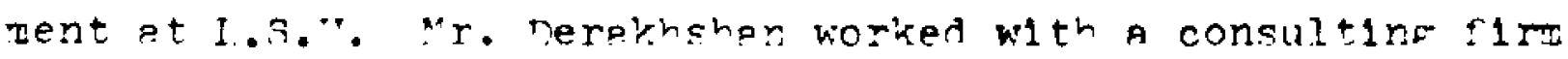
In Iran, ond is nresently a facilty meghen of Indiano indy sity. 
Candidate: $\quad$ Foad Derakhshan

Major Field: Management

Title of Theis: A study of the relationships between span o1 supervision and leadership directiveness in Fast-Food Restaurants

Approved:
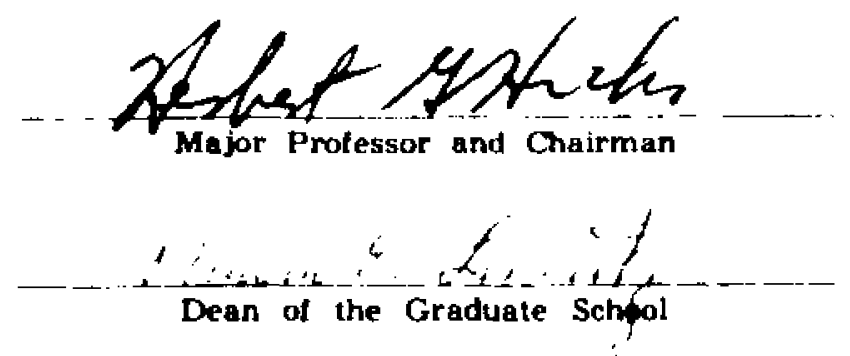

EXAMINING COMMITTEE:

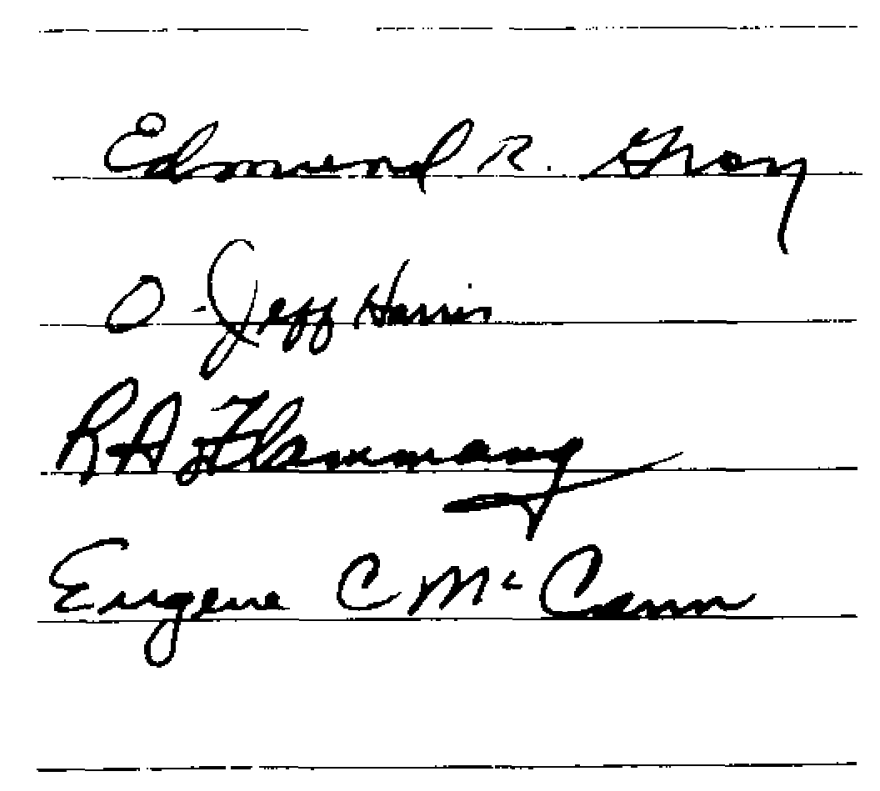

Date of Examination: 